\title{
Dam-Breach Analysis and Flood-Inundation Mapping for Lakes Ellsworth and Lawtonka near Lawton, Oklahoma
}

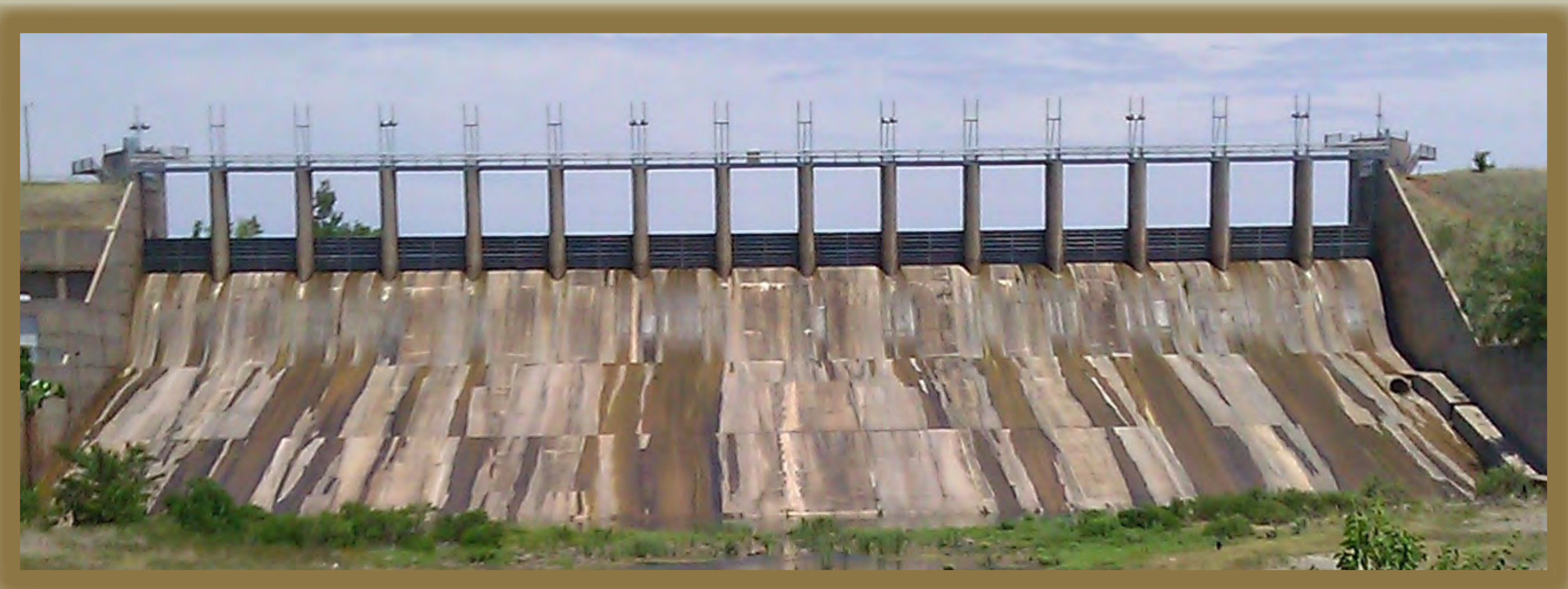

Scientific Investigations Report 2012-5026 

Dam-Breach Analysis and Flood-Inundation Mapping for Lakes Ellsworth and Lawtonka near Lawton, Oklahoma

By Samuel H. Rendon, Chad E. Ashworth, and S. Jerrod Smith

In cooperation with the city of Lawton

Scientific Investigations Report 2012-5026

U.S. Department of the Interior

U.S. Geological Survey 


\section{U.S. Department of the Interior}

KEN SALAZAR, Secretary

\section{U.S. Geological Survey}

Marcia K. McNutt, Director

U.S. Geological Survey, Reston, Virginia: 2012

This and other USGS information products are avaliable at http://store.usgs.gov/

U.S. Geological Survey

Box 25286, Denver Federal Center

To learn about the USGS and its information products visit http://www.usgs.gov/

-888-ASK-USGS

Any use of trade, product, or firm names is for descriptive purposes only and does not imply endorsement by the

U.S. Government.

Although this report is in the public domain, permission must be secured from the individual copyright owners to reproduce any copyrighted materials contained within this report

Suggested citation:

W. CE , and Smith S. J. 2012. Dam-breach analysis and flood-inundation mapning for Lakes Ellsworth and Lawtonka near Lawton, Oklahoma: U.S. Geological Survey Scientific Investigations Report 2012-5026, 56 p.

\section{Contents}

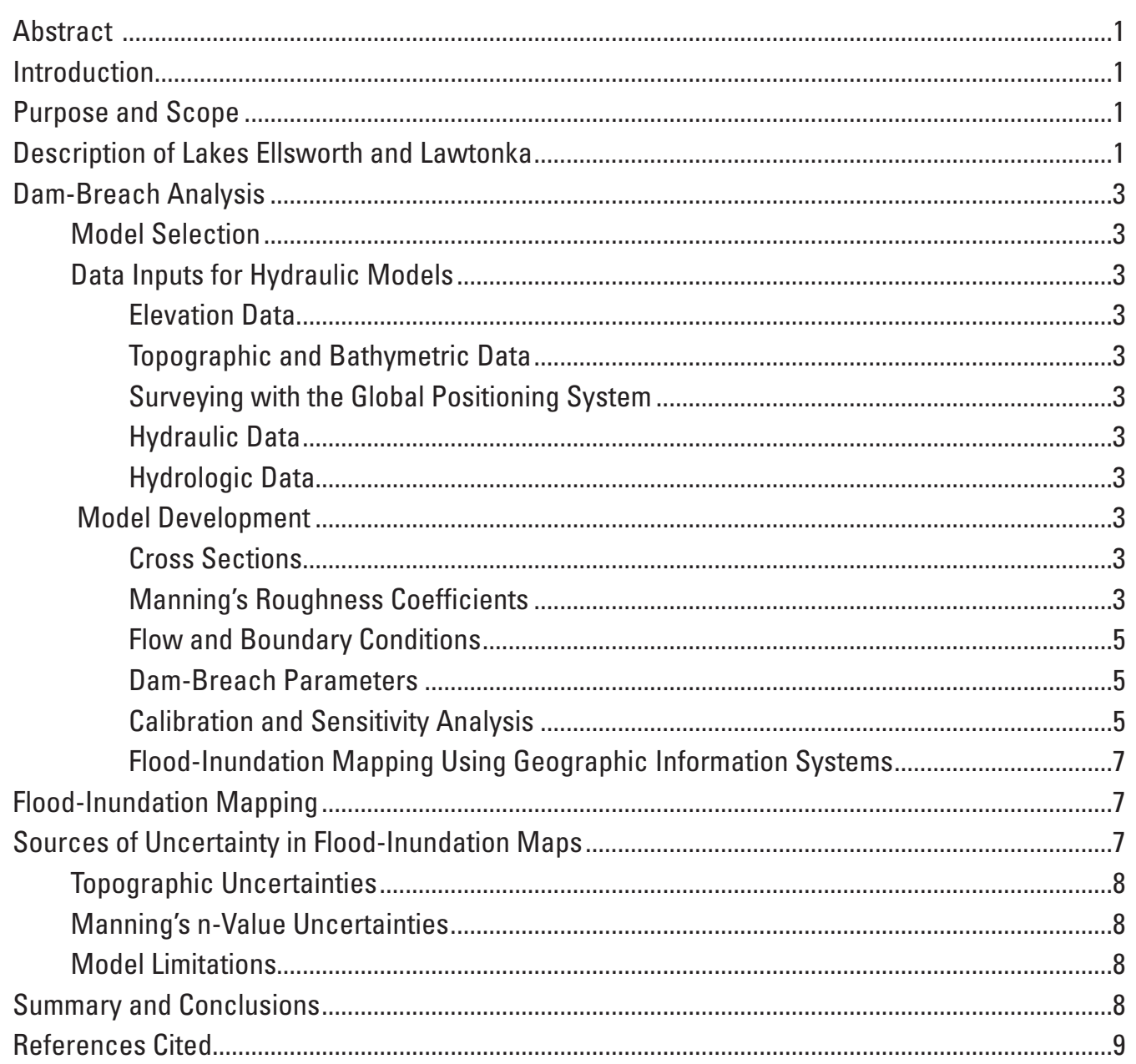




\section{Figures}

. Map showing study area for Lakes Ellsworth and Lawtonka near

Lawton, Oklahoma ....................................................................................

2. Map showing collection area of light detection and ranging
from Lakes Ellsworth and Lawtonka near Lawton, Oklahoma,

to U.S. Geological Survey streamflow-gaging station East Cache Creek near Walters, Okla. (07311000), with merged National Elevation Datase and lidar-derived digital elevation model

3. Graph showing cross section derived with light detection and ranging (lidar) with and without use of the cross-section-point filter tool in the Hydrologic Engineering Center's River Analysis System modeling software .....................

4. Map showing spatial distribution of initial Manning's roughness coefficients for the study are for the calibrated models of East Cache and Medicine Creeks between Lakes Ellsworth and Lawtonka near Lawton, Oklahoma

Tables

Manning's roughness coefficients (n-values) for the calibrated models of East Cach and Medicine Creeks between Lakes Ellsworth and Lawtonk and Mearicine Creeks betwi

2. Values of $C$ offset factor, a funcion of resevorvolume

from Von Thun and Gillette (1990) for the calibrated models

of East Cache and Medicine Creeks between Lakes Ellsworth and Lawtonka

.

Values of dam-breach parameters used for Lakes Ellsworth and Lawtonka Dams

ear Lawton, Oklahoma.

4. Maximum flood-inundation elevation and time for 75 -percent probable maximum flood and sunny-day dam-breach scenarios for Lakes Ellsworth Peak water-surface elevation and time to peak for the sensitivity analysis

5. Peak water-surface elevation and time to peak for the sensituly analysis flood of Manning's rought ofss coeficients for the 75 percent probable maximum flood

\section{Appendixes}

. Map extents for figures in appendixes 2-5 for the dam-breach analysis and flood-inundation mapping for Lakes Ellsworth and Lawtonka near Lawton, Oklahoma...

2. Cross-section locations for Lake Ellsworth, near Lawton, Oklahoma, for
the Hydrologic Engineering Center's River Analysis System model .....................................13

Cross-section locations for Lake Ellsworth, near Lawton, Oklahoma, for
the Hydrologic Engineering Center's River Analysis System model ......................................13
3. Inundated areas for dam-breach scenarios for Lake Ellsworth, near Lawton, Oklahoma, modeled by using the Hydrologic Engineering Center's River Analsis Systrm modeling software

4. Cross-section locations for Lake Lawtonka, near Lawton, Oklahoma for the Hydrologic Engineering Center's River Analysis System model

5. Inundated areas for dam-breach scenarios for Lake Lawtonka, near Lawton, Oklahoma, modeled by using the Hydrologic Engineering Center's

\section{Conversion Factors and Datums}

Inch/Pound to SI

\begin{tabular}{|c|c|c|}
\hline Multiply & By & To obtain \\
\hline \multicolumn{3}{|c|}{ Length } \\
\hline inch (in.) & 2.54 & centimeter $(\mathrm{cm})$ \\
\hline foot (ft) & 0.3048 & meter (m) \\
\hline mile (mi) & 1.609 & kilometer (km) \\
\hline \multicolumn{3}{|c|}{ Area } \\
\hline square mile $\left(\mathrm{mi}^{2}\right)$ & 259.0 & hectare (ha) \\
\hline square mile $\left(\mathrm{mi}^{2}\right)$ & 2.590 & square kilometer $\left(\mathrm{km}^{2}\right)$ \\
\hline \multicolumn{3}{|c|}{ Volume } \\
\hline cubic foot $\left(\mathrm{ft}^{3}\right)$ & 0.02832 & cubic meter $\left(\mathrm{m}^{3}\right)$ \\
\hline acre-foot (acre-ft) & 1,233 & cubic meter $\left(\mathrm{m}^{3}\right)$ \\
\hline acre-foot (acre-ft) & 0.001233 & cubic hectometer $\left(\mathrm{hm}^{3}\right)$ \\
\hline \multicolumn{3}{|c|}{ Flow rate } \\
\hline cubic foot $\mathrm{p}$ & 0.02832 & cubic meter per second \\
\hline
\end{tabular}

Vertical coordinate information is referenced to the North American Vertical Datum of 1988 (NAVD 88) or National Geodetic Vertical Datum of 1929 (NGVD 29).

Horizontal coordinate information (U.S. Survey Feet) is referenced to the North American Datum (NAD

A U.S. Survey Foot is defined as follows: 1 meter $=39.37$ inches. Dividing 39.37 inches by $12(12$ inches per foot), the resulting conversion factor is 1 meter $=3.280833333$. U.S. Survey Feet (reference www.ngs noaa.gov/faq.shtml). 



\section{Dam-Breach Analysis and Flood-Inundation Mapping for Lakes Ellsworth and Lawtonka near Lawton, Oklahoma}

By Samuel H. Rendon, Chad E. Ashworth, and S. Jerrod Smith

\section{Abstract}

Dams provide beneficial functions such as flood control, recreation, and reliable water supplies, but they also entail risk: dam breaches and resultant floods can cause substantial property damage and loss of life. The State of Oklahoma requires each owner of a high-hazard dam, which the Federal Emergency Management Agency defines as dams for which failure or misoperation probably will cause loss of human life, to develop an emergency action plan specific to that dam. Components of an emergency action plan are to simulate a flood resulting from a possible dam breach and map the resulting downstream floodinundation areas. The resulting flood-inundation maps can provide valuable information to city officials, emergency managers, an local residents for planning the emergency response if a dam breach occurs.

Accurate topographic data are vital for developing floodinundation maps. This report presents results of a cooperative study by the city of Lawton, Oklahoma, and the U.S. Geological Survey (USGS) to model dam-breach scenarios at Lakes Ellsworth and Lawtonka near Lawton and to map the potential flood-inundation areas of such dam breaches. To assist the city of Lawton with completion of the emergency action plans for Lakes Ellsworth and Lawtonka Dams, the USGS collected light detection and ranging (lidar) data that were used to develop a highmop for the flood phins dowstron fon Lawtonka. This digital elevation model and field treamflow-gaging station dast (USS streamflow-gaing station 07311000, East Cache Crek (US Walters, Okla), and hydralic values were used as inputs for the dynamic (unsteady-fow) model, Hydrologic Engineering Center's River An lysis Systen (HEC-RAS). The modeled flood elevations were exported to a geographic information system to produce flood-inundation maps. Water-surface profiles were developed for a 75 -percent probable maximum flood scenario and a sunny-day dam-breach scenario, as well as for maximum flood-inundation elevations and flood-wave arrival times for selected bridge crossings. Some areas of concern near the city of Lawton, if a dam breach occurs at Lakes Ellsworth or Lawtonka, include water treatment plants, wastewater treatme plants, recreational areas, and community-services offices.

\section{Introduction}

Dams have altered the flow of many of the Nation's rivers to meet societal needs such as hydropower, recreation, supply, irrigation, and flood control (Collier and others, 1996). Althoug dams provide many benefits, they also entail risk: dam breaches have produced catastrophic floods. A dam breach can lead to rap flood inundation downstream, causing fatalities and extensive damage to infrastructure and the landscape. Some notable historic dam breaches include St. Francis Dam in California, 1928 (Rogers, 2006); Teton Dam in Idaho, 1976 (Arthur, 1977); and Buffalo Creek Dam in West Virginia, 1972 (Davies and others, 1972).

The city of Law ton, Oklahoma, owns and operates two reservoirs: Lake Lawtonka on Medicine Creek and Lake Ellswo on East Cache Creek (fig. 1). Lake Lawtonka serves primarily as a water-supply reservoir for the city of Lawton. Water is pumped directly from Lake Lawtonka to the Medicine Park Wat reatment Plant for treatment and distribution to the City of Lawton's water users. Lake Lawtonka is also used for flood contro and recreation. Lake Ellsworth serves as a secondary water-supply reservoir to Lake Lawtonka and is also used for flood control and recreation (Oklahoma Water Resources Board, 2005). When needed, water is pumped from Lake Elsworh to Lake Law tonka and then to the Medicine Park Water Treatment Plant for treatm

The 4,600 drin Emere which failue or misoperation probably will cass bos of hech Oklahoma Water Resources Board requires that any entity owning a dam classified as high hazard must develop an emergency action plan (EAP) (Oklahoma Water Resources Board, 2011), one component of which is to map or delineate areas of potentin flood inundation resulting from a dam breach. Knowledge of the flood wave and flood-inundation area caused by a dam breach can potentially mitigate loss of life and property damage.

A flood produced by a dam breach is very different from a flood produced by a rainfall event. In a dam-breach scenario, the subsequent flood wave develops over a relatively short time and life (Federal Emergency Management Agency, 1998). The flows rapidly through the downstream area as opposed to a rainfall event that would propagate more slowly through the downstrean area. Dam-breach analysis and flood-inundation maps are vital for providing data to emergency managers and other decisionmaker to better plan for and respond quickly and effectively to flooding. A cooperative study by the city of Lawton and the U.S. Geologic Survey (USGS) was done to simulate dam-breach scenarios a Lakes Ellsworth and Lawtonka near Lawton and to map the potentially resulting flood-inundation areas.

Development of accurate flood-inundation maps require high-resolution topographic data of known accuracy. More accurate topographic data lead to more accurate flood-inundatio maps (Horritt and Bates, 2001). Field surveying produces the most accurate elevation data but can be time consuming and expensive. Light detection and ranging (lidar) is an airborne laser-profiling system that produces location and elevation data to define the surface of the Earth and the heights of aboveground features.

Lidar can produce a digital elevation model (DEM) with 1-foot (ff) (GIS) in a relatively short amount of time.

Dam-breach flood-inundation maps indicate areas that would be flooded as a result of a dam failure. The inundated areas depicted on flood-inundation maps are approximate, and accuracy of such maps is a function of the accuracy of the topographic data the hydraulic models on which the maps are based, the assumption made about the dam failure mode, and the initial flood wave. For this report, lidar data with a vertical accuracy of about 3.3 inches (in) were used to develop a 1 -ft contour elevation map for the study area near the city of Lawton. The Hydrologic Engineering Center's River Analysis System (HEC-RAS) modeling software developed by the U.S. Army Corps of Engineers, a standard for dam-breach flood-inundation models, was used to perform unsteady-flow imulations to model the dynamic nature of the flood wave produced by a dam-breach scenario (Hydrologic Ensinering Center 2010a). Two models, Lawtonka, were developed for dam-breach simulations.

\section{Purpose and Scope}

The purpose of this report is to document the methods and flood-inundation maps for the affected areas downstream from Lakes Ellsworth and Lawtonka near Lawton. Results presented in this report can be used to assist the city of Lawton in identifying and mitigating areas at risk if a dam breach occurs. Results also can be used to assist the city of Lawton by providing (1) floodinundation maps, (2) hydraulic models, (3) topographic data for the study area, and (4) detailed hydraulic information about reaches in the study area.

\section{Description of Lakes Ellsworth and Lawtonka}

Lake Ellsworth is located 11 miles (mi) northeast of the city Cache Creek are in the Wichita Mountains in Caddo County, Okla. Lake Ellsworth's normal pool elevation, referenced to the National Geodetic Vertical Datum of 1929 (NGVD 29), is 1,232.5 $\mathrm{ft}$, with maximum pool storage of $1,235 \mathrm{ft}$; it covers approximately 5,113 acres with a storage volume of 81,224 acre-ft (Oklahoma Water Resources Board, 2005). Lake Lawtonka is located $11 \mathrm{mi}$ north of the city of Lawton on Medicine Creek (fig. 1) (Oklahoma Water Resources Board, 2006). The headwaters for Medicine Creek are in the Wichita Mountains in Caddo County. The norma pool elevation is 1,343.35 ft (NGVD 29) with maximum pool elevation of 1,345.55 ft; the lake covers approximately 2,375 acres with a storage volume of 63,000 acre-ft (Oklahoma Water Resources Board, 2006).

Both Lakes Ellsworth and Lawtonka Dams are classified as large, high-hazard dams. Lake Ellsworth Dam, constructed between 1959 and 1961, with gates added in 1969, is a combination earth-fill and concrete dam that is approximately $3,900 \mathrm{ft}$ long and $96 \mathrm{ft}$ high (Oklahoma Water Resources Board, 2005). The top of the dam is at elevation 1,250 ft (NGVD 29) (Oklahoma Water Resources Board, 2005). Lake Lawtonka Dam, complete in 1907 and upgraded as recently as 1954, is a combination of masonry and concrete material and is approximately $612 \mathrm{ft}$ long and $90 \mathrm{ft}$ high (Oklahoma Water Resources Board, 2006). The top of the dam is at elevation $1,355 \mathrm{ft}$ (NGVD 29) (Oklahoma Water Resources Board, 2006).

The drainage basins for East Cache and Medicine Creeks are underlain by multiple geologic formations. The flood plain is underlain by thick and highly erodible alluvial clays, sands, and silts (Bureau of Reclamation, 1996). The local vegetation can be separated into three distinct categories: (1) tall grass prairie, (2) mixed grass eroded plains, and (3) flood-plain forest (Bureau of Reclamation, 1996).

The modeled reach for Medicine Creek is approximately 68 river miles long and begins with Lake Lawtonka, runs through the town of Medicine Park, Okla, and then Fort Sill U.S. Army Base (see fig. 1-1 in app. 1), joins with East Cache Creek north of the city of Lawton, and then follows East Cache Creek to the town of Walters, Okla. The modeled reach of East Cache Creek is 75 river miles long and begins with Lake Ellsworth, runs through portion of Fort Sill U.S. Army Base and through the city of Lawton, and terminates at the town of Walters. 

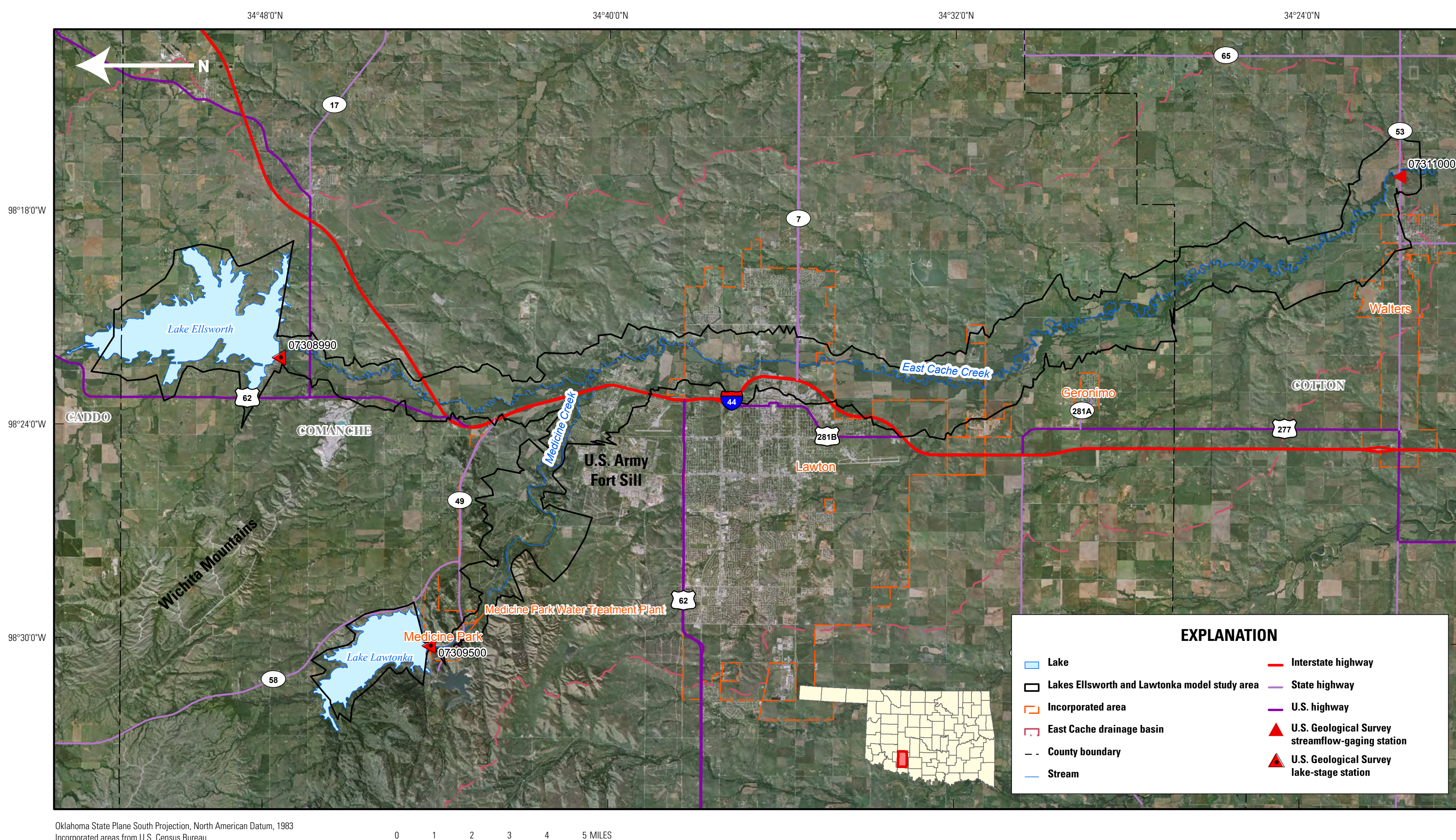

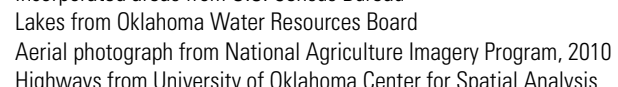

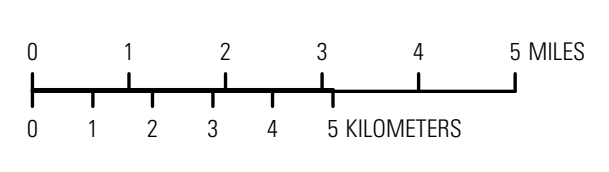

Figure 1. Study area for Lakes Ellsworth and Lawtonka near Lawton, Oklahoma. 


\section{Dam-Breach Analysis}

Previously collected data used for this analysis included streamflow data from USGS streamflow-gaging station East Cache Creek near Walters, Okla. (07311000); lake-gage data from statio from station Lake Lawtonka near Lawton, Okla. (07309500); an bathymetric surveys of Lakes Ellsworth and Lawtonka (Oklahoma Water Resources Board, 2005, 2006). New data used for this analysis included aerial lidar data, surveying data, and hydraulic and hydrologic measurements.

\section{Model Selection}

Version 4.1 of the one-dimensional dynamic (unsteady-flow) modeling software HEC-RAS was used to simulate flow in the study area (Hydrologic Engineering Center, 2010a). HEC-RAS can perform one-dimensional river analysis, in which the watersurface elevation is assumed to be constant over each comput
section, in one of four modes: (1) steady-flow water-surface profile computations, (2) unsteady-flow water-surface profile computations, (3) sediment-transport computations, and (4) waterquality analysis. Given the dynamic nature of the flood wave produced by a dam breach, as well as the size and geometry of the reservoirs in question, the unsteady-flow water-surface profile computation conponent was used for both dam-breach scenarios. Unsteady-flow HEC-RAS is capable of simulating subcritical as well as supercritical flows, both of which were produced in the simulations. For most of the modeled reaches, the flow was subcritical, with the velocity of flow being slower than the speed that a wave would propagate; however, supercritical flow, flow wit velocity faster than the wave propagation speed, was likely to occu

\section{Data Inputs for Hydraulic Models}

Elevation Data

Development of accurate hydraulic models requires accurate topographic data. Accurate land-surface elevation data determine the topography that defines the hydraulic conditions from which the model computes flood elevations.

\section{Topographic and Bathymetric Data}

A high-resolution digital elevation model (DEM) was developed from lidar data for a 1-mi buffer area around East Cache Creek and Medicine Creek, from Lakes Ellsworth and Lawtonka to USGS streamflow-gaging station East Cache Creek near Walters, approximately 100 square miles near the city of Lawton. Lidar elevation data were collected at an average of $2.3 \mathrm{ft}$ point spacin or finer and a vertical accuracy of $0.3 \mathrm{ft}$ root mean squared error (RMSE) at the 95 percent confidence level for bare, flat ground.
The lidar data were collected in December 2010 during leaf-off, snow-free conditions, when water levels in streams were below ank-full stage (Williams, 2010)

Lidar elevation data were postprocessed to produce a "bareearth" model that was suitable for the production of a DEM with 1-ft contours that met or exceeded National Digital Elevation Program (2004) standards. Lidar elevation data were in Oklahom Sta ( North American Vertical Datum of 1988 (NAVD 88) (GEO the (Wel), wh orth (Williams, 2011).

Hydroflattened break lines, which are used to characterize the locations of streams and other major topographic or hydrologic features, were produced along stream edges and water bodies to augment the terrain dataset for generation of $1-\mathrm{ft}$ contours and for water-point classification. The 1 -ft contours were generated from the bare-earth lidar model and the collected hydroflattened break lines and were then compiled into a shapefile for use in ArcMap ${ }^{\mathrm{TM}}$ (Environmental Systems Research Institute, 2011).

The lidar data were tested for both vertical and horizontal accuracy as described in National Digital Elevation Program (2004). The accuracy testing included obtaining at least 40 groun control survey points randomly selected throughout the study area for quality-control purposes. These areas were characterize by (1) bare-ground, (2) low-vegetation, and (3) high-vegetation conditions. The final RMSE of the lidar data was 3.31 in. (Williams, 2011)

Topographic data were input into HEC-GeoRAS (Hydrologic Engineering Center, 2011), a toolbox for ArcGISTM (Environmen Systems Research Institute, 2011), to determine elevation points in each cross section (appendixes 1-5; see Model Development
section of this report). Lidar-derived DEM tiles were merged to section of this report). Lidar-derived DEM tiles were merged to J litio $2000 \mathrm{ft}(\mathrm{fe}, 2)$. The Nation DEM for the buffered area (U.S. Geological Survey, 2011) was Drojected and resampled fos a gid size of $10 \mathrm{~m}$ to a gid sice of $2 \mathrm{ft}$ and merged with the lidar-derived DEM to extend topographic coverage beyond the area of the lidar survey. Bathymetric dap for Lakes Ellsworth and Lawtonka (Oklahoma Water Resources Bor 2005,2006 ) were merged with the lidar data to generate a complete opographic/bathymetric representation of the East Cache Creek watershed.

Surveying with the Global Positioning System

Additional topographic data were collected by use of a U.S. Survey-grade real-time kinematic Global Positioning System (RTK-GPS) receiver. A Trimble R8 Global Navigation Satellite 0.4 in. horizontally and 0.8 in. vertically (Trimble Navigation Limited, 2003)

Additional survey data were collected to define features in the study area and for quality-control purposes. Survey data were used to help define the tops of roads, as well as the streambed as lidar does not measure at several points in the lidar survey area along East Cache and Medicine Creeks for quality-control purposes. Elevations were measured at nearby high-accuracy reference network (HARN) arkers to ensure a set of constant points for geodetic control. The RTK-GPS data were collected by using the GEOID03 model and were postprocessed by using the Trimble Geomatics Office software (Trimble Navigation Limited, 2005). The survey data were referenced to the National Geodetic Survey's network of Continuously Operating Reference Stations (CORS) network (National Geodetic Survey, 2011)

\section{Hydraulic Data}

Bridges and channel roughness have substantial effects on the hydraulic properties of streams. Roughness coefficients were determined throughout the study area by using Manning's roughness coefficient, a value used to describe a channel roug or resistance to flow (Arcement and Schneider, 1989). Bridge dimensions including width, length, pier diameter, pier location, bridge surface to low chord (which is the lowest point of the bridge deck), and bridge surface to land surface were measured at al locations in the study area by using an engineer's steel tape. Digital photographs were taken at each bridge site in multiple directions to document conditions and to provide a check for cross sections in the model.

\section{Hydrologic Data}

Two scenarios were required for each dam-breach simulation: (1) a dam breach during 75 percent of the probable maximum flood (PMF) and (2) a dam breach during normal flow conditions without precipitation (sunny-day dam breach). Both of those scenario have been established by the Oklahoma Water Resources Board requirements for dam-breach studies (Oklahoma Water Resources Board, 2011)

Streamflow and water-level data from USGS streamflowgaging station East Cache Creek near Walters, Okla. (07311000), were used as hydrologic inputs for the HEC-RAS model to help quantify the sunny-day dam-breach scenario. East Cache Creek near Walters, Okla. (07311000), is a real-time USGS streamflowgaging station with a water-stage recorder. The datum of the gage is $938.2 \mathrm{ft}$ (NGVD 29) (U.S. Geological Survey, 2010). The periods of record for this streamflow-gaging station are May 1938 to December 1963 and October 1969 to the present (2011). Prior to October 1969, data from the East Cache Creek near Walters, Okla. (07311000), streamflow-gaging station were published as being from Cache Creek near Walters, Okla. (07311000) (U.S. Geologica Survey, 2010). Previous studies such as Bureau of Reclamation (1996) and CH2MHill (2000) were used to quantify the PMF flow rates for both lakes. It was assumed that there were no local inflows from tributaries to either East Cache Creek or Medicine Creek for both the 75-percent-PMF and sunny-day dam-breach scenarios.

\section{Model Development}

Development of an unsteady-flow HEC-RAS model require six major types of data: topographic data, cross-section data, Manning's roughness coefficient n-values, bridge geometry, an flow and boundary conditions. These datasets were derived from existing data by using HEC-GeoRAS (Hydraulic Engineering Center, 2011) and data from previous hydraulic and hydrologic studies and field surveys.

Cross Sections

HEC-RAS requires cross sections for water-surface computations. Cross sections are drawn perpendicular to streamflow. Approximately 300 cross sections were delineated manually for each model by using HEC-GeoRAS at about 1,000-ft intervals (appendixes 1-5). Elevation data then were extracted from the merged lidar/NED DEM and imported into HEC-RAS. Each cross section ideally is perpendicular to flow, can intersect the main channel only once, and may not intersect anothe cross section (Hydrologic Engineering Center, 2010b); however, keeping the cross sections perfectly perpendicular to flow was not possible at some locations,

The lidar/NED-derived cross sections were used to create opproximately 20 additional interpolated cross sections for both

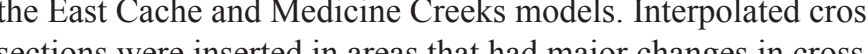
section hydruulics. HEC-RAS can manage only 500 elevation points per cross section; thus, the cross-section-points fiter tool pof HEC-RAS was used to resample both the lidar-derived and he interpolated cross sections down to 490 poins As show in figure 3 , use of the cross-section-points filter tool preserves the general shape of the cross section as it filtered the number of points down to 490 elevation points. A 10 -elevation-point buffer was used to account for ineffective flow areas and any levees defined in the model that might be added later after the cross-section-points filte tool was used.

\section{Manning's Roughness Coefficients}

In HEC-RAS, Manning's roughness coefficient ( $n$, which is corollary to the friction created by the roughness of the channel) values can be varied horizontally across any given cross section. Manning's roughness coefficient values were determined by (1989). Bues described by Barnes (1967), Arcement and Schneider Manning's roughness coefficient following techniques: (1) the 2001 National Land Cover Dataset (NLCD; Multi-Resolution Land Characteristics Consortium, 2008) was retrieved for the study area, and (2) because HEC-RAS can handle only 20 different $n$ values per cross section, the downloaded land-use/land-cover data were reclassified into five roughness classes each with their own individual $\mathrm{n}$ value. The land-use/ land-cover data with the five simplified roughness classes and the respective $\mathrm{n}$ values for the calibrated models are listed in table 1. 


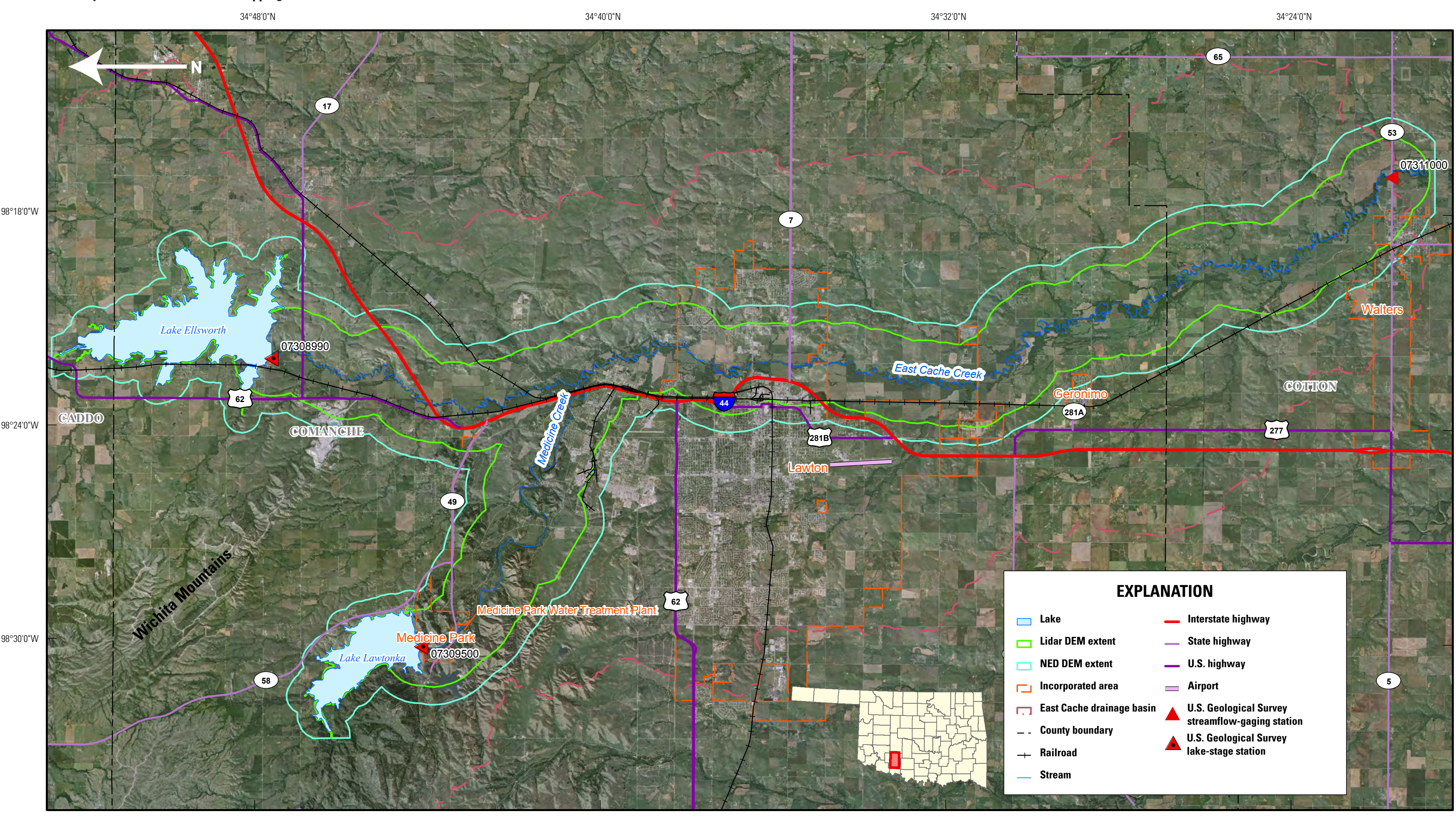

Okahama State Plane South Projection, North American Datum, 1983 Incorporated areas from W.S.C. Censul Bureau
Lakes from Okkahoma Water Resources Baord

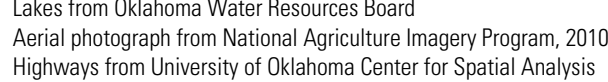

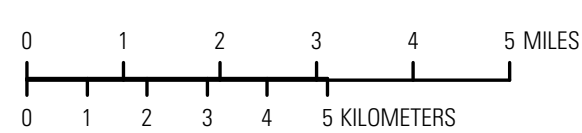

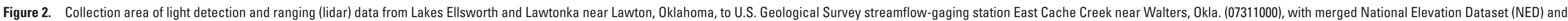
lidar-derived digital elevation model (DEM). 


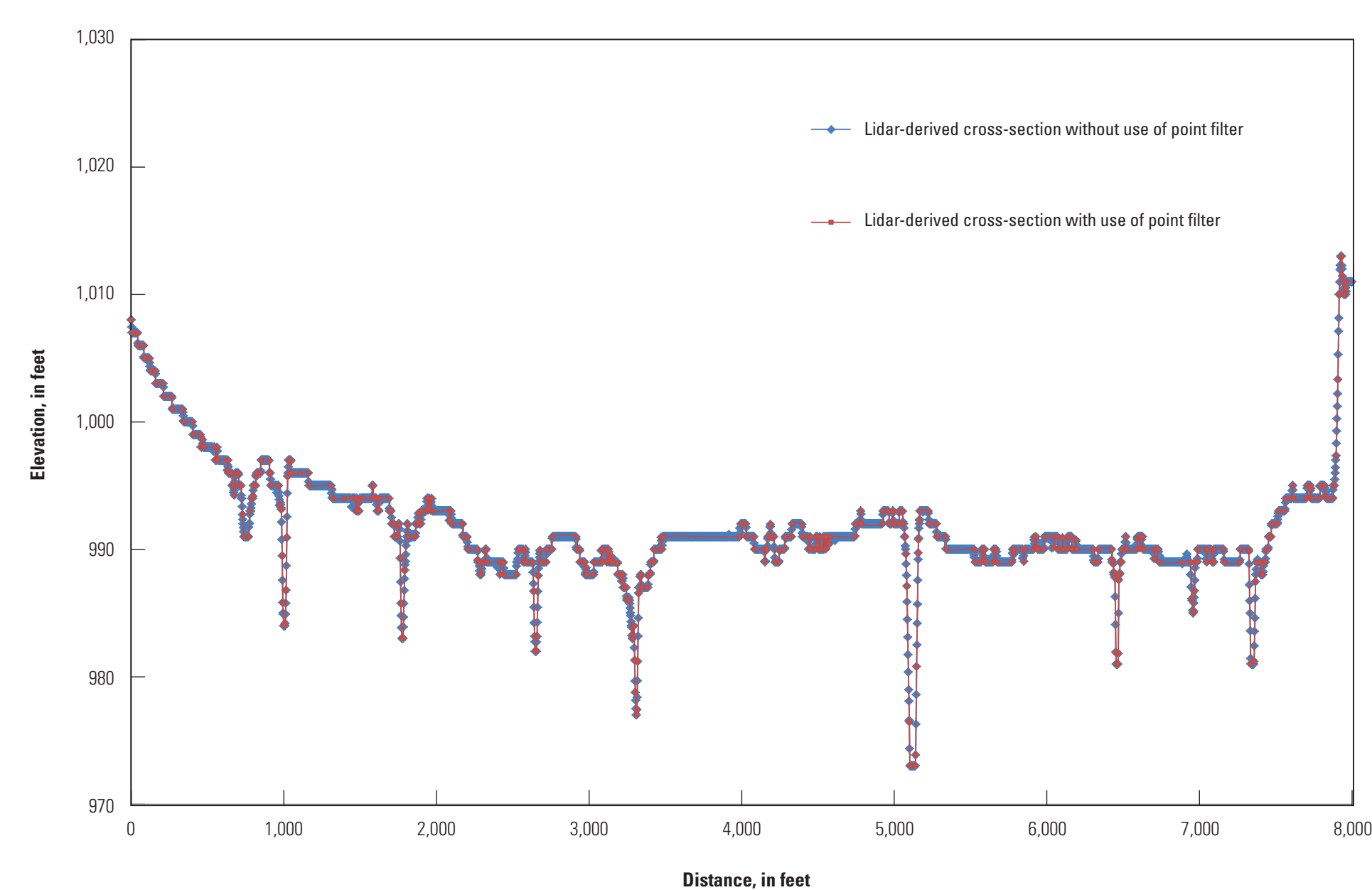

Figure 3. Cross section derived with light detection and ranging (lidar) with and without use of the cross-section-point filter tool in the Hydrologic Engineering Center's River Analysis System (HEC-RAS) modeling software (Hydrologic Engineering Center, 2010a).

Table 1. Manning's roughness coefficients (n-values) for the calibrated models of East Cache and Medicine Creeks between Lakes Ellsworth and Lawtonka near Lawton, Oklahoma.

\begin{tabular}{clccc} 
Land-use code & \multicolumn{1}{c}{ Name } & Land-use class & $\begin{array}{c}\text { Calibrated Manning's } \\
\text { roughness coefficent }\end{array}$ & $\begin{array}{c}\text { Initial Manning's } \\
\text { roughness coefficent }\end{array}$ \\
\hline 11 & Open water & 1 & 0.045 & 0.042 \\
21 & Developed, open space & 2 & .075 & .035 \\
22 & Developed, low intensity & 3 & .225 & .1 \\
23 & Developed, medium intensity & 3 & .225 & .1 \\
24 & Developed, high intensity & 3 & .225 & .1 \\
31 & Barren land & 4 & .0825 & .04 \\
41 & Deciduous forest & 5 & .3 & .15 \\
42 & Evergreen forest & 5 & .3 & .15 \\
52 & Shrub/scrub & 5 & .3 & .15 \\
71 & Grassland & 4 & .0825 & .04 \\
81 & Pasture & 4 & .0825 & .04 \\
82 & Cultivated crop land & 4 & .0825 & .04 \\
95 & Wettland & 5 & .3 & .15 \\
\hline
\end{tabular}

The average channel $n$ values were 0.047 for both models, and the average overland $\mathrm{n}$ values were 0.083 and 0.081 for the East Cache and Medicine Creek basins, values are very similar to those described in Bureau or Reclamation (n) for the study area is shown in figure 4 .

\section{Flow and Boundary Conditions}

Initial flow values, input hydrographs, and downstream boundary conditions must be set in a HEC-RAS model. For this report, the initial flow was set at 200 cubic feet per second $\left(\mathrm{ft}^{3} / \mathrm{s}\right)$, which is less than the 2-year peak flow and approximately the 20 percent probability of flow exceedance recorded at the USGS streamflow-gaging station East Cache Creek near Walters, Okla. (07311000) (Lewis and Esralew, 2009). The 200-ft's initial flow value also was used as the flow-rate input for the sunny-day dambreach scenario. The input hydrograph for the 75-percent PMF for each of the individual models was obtained from previous reports such as Bureau of Reclamation (1996) and CH2MHILL (2000) for East Cache and Medicine Creeks. The downstream slope of 0.0006 , which is equal to the average slope of both East Cache and Medicine Creeks.

\section{Dam-Breach Parameters}

An estimate of the dam-breach bottom width and time of full ailure for use in the Lake Ellsworth and Lake Lawtonka models as obtained by using three different dam-breach-sizing equation

where

$$
B=3 h_{v}
$$

$B$ is the average dam-breach-bottom width, in meters; an $h$ is the volume of water above the dam-breach invert at time of failure, in cubic meters;

Von Thun and Gillette (1990):

$$
\text { where } \quad B=2.5 h_{w}+C_{b}
$$

$B$ is the average dam-breach-bottom width, in meters

$h_{w}$ is the volume of water above the dam-breach invert at time of failure, in cubic meters; and

$C_{b}$ is an offset factor that is a function of reservoir volume (table 2); and

Froehlich (1995):

$$
B=0.1803 K V_{w}^{0.32} h_{b}^{0.19}
$$

$B$ is the average dam-breach-bottom width, in meters; $K \quad$ is an overtopping multiplier with 1.4 being used for overtopping and 1.0 being used for a piping failure in water above the dam-breach invert at is the of failure, in cubic meters, and

Values of $\boldsymbol{C}_{b}$ offset factor, a function of reservoir volume, from Von Thun and Gillette (1990) for the calibrated models of East Cache and Medicine Creeks between Lakes Ellsworth an For near Lawton, Oklahoma.

For each of hose dam-breach-width determination equations

Bureau of Reclamation (1988):

$$
t=0.011 B
$$

where

is the time to full failure, in hours; and

$B$ is the average dam-breach-bottom width in meters;

Von Thun and Gillette (1990):

$$
\text { For highly erodible dams } \quad t=B /\left(4 h_{w}\right)
$$

where

$$
\text { For erosion-resistant dams } \quad t=B /\left(4 h_{w}+61\right)
$$

is the time to full failure, in hours

$B$ is the average dam-breach-bottom width, in meters; an v is the volume of water above the dam-breach invert at time of failure, in cubic meters; and

Froehlich (1995)

$$
t=0.00254 K V_{w}^{0.53} h_{b}^{-0.9}
$$

where

$t$ is the time to full failure, in hours;

is an overtopping multiplier where 1.4 is used for overtopping and 1.0 is used for a piping failure, invert at time of failure, in cubic meters;

$h_{b}$ is the height of the dam breach, in meters.

A summary of the resultant dam-breach parameters for each of these respective equations is listed in table 3 , in which the resultant parameters were converted from Systeme International (SI) units to inch/pound units for use in the models. Each set of resultant dambreach parameters was evaluated at the dam-breach location for the resulting flow hydrograph, with an average of the dam-breach parameters for each of the dams yielding a conservative estimate of the dam breach.

\section{Calibration and Sensitivity Analysis}

Each model was calibrated by using available data from USGS streamflow-gaging station East Cache Creek near Walters, Okla 25-, 50-, 100-, and 500-year recurrence intervals and then were compared to measured stage-discharge relations at the streamflowgaging station. Manning's roughness coefficients were then adjusted 

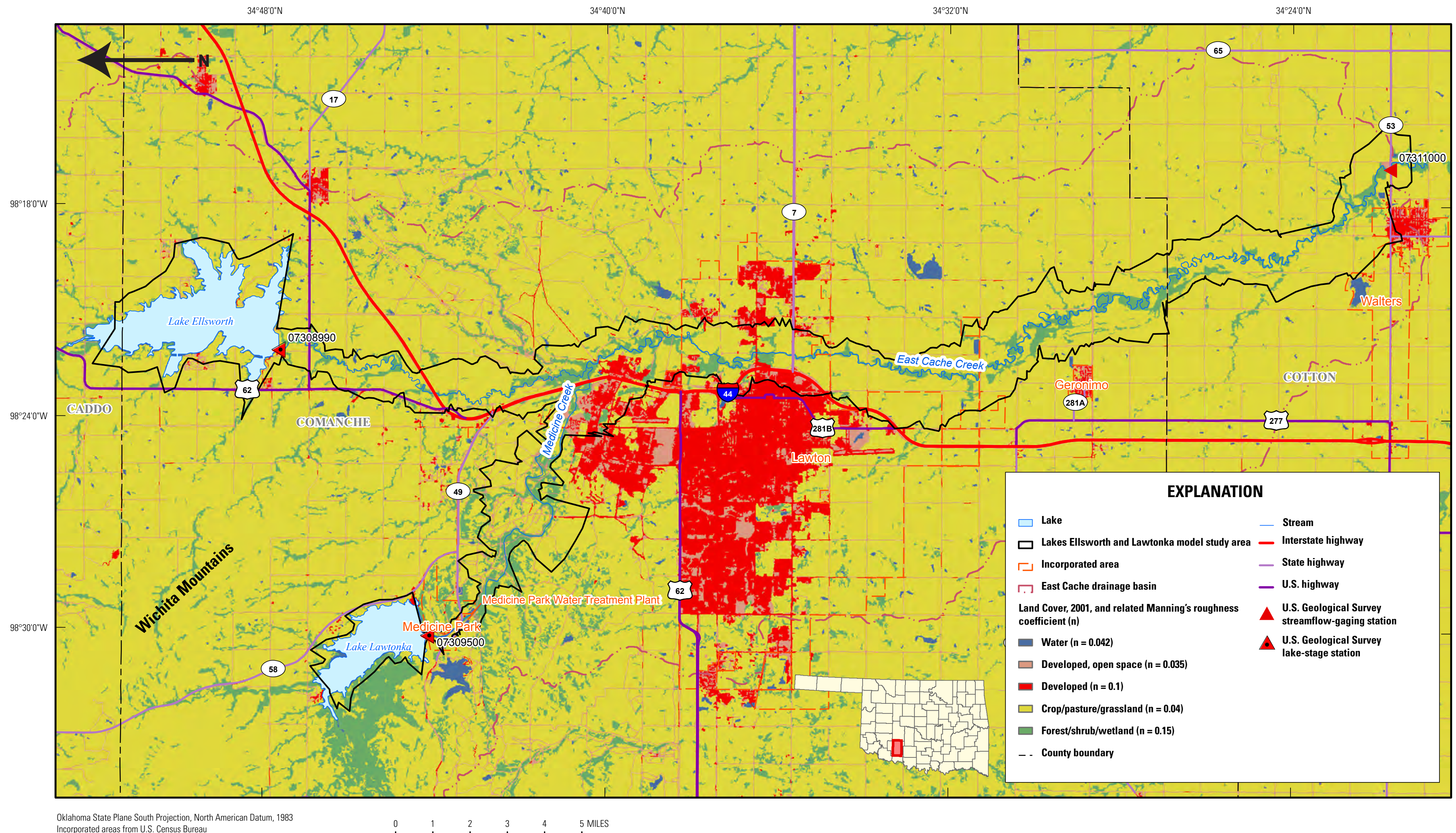
Lakestrom Oklahoma Water Resources Boarc

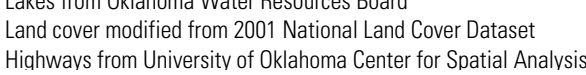

Figure 4. Spatial distribution of initial Manning's roughness coefficients for the study area for the calibrated models of East Cache and Medicine Creeks between Lakes Ellsworth and Lawtonka near Lawton, Oklahoma. 
Table 2. Values of $C_{b}$ offset factor, a function of reservoir volume from Von Thun and Gillette (1990) for the calibrated models of East Cache Lawtonka near Lawton, Oklahoma.

\begin{tabular}{cc}
\hline Size of reservoir, in cubic meters & $\boldsymbol{C}_{\boldsymbol{b}^{\text {i }}}$ in meters \\
\hline$<1.23^{*} 10^{6}$ & 6.1 \\
$1.23 * 10^{6}-6.17^{*} 10^{6}$ & 18.3 \\
$6.17^{*} 10^{6}-1.23^{*} 10^{7}$ & 42.7 \\
$>1.23^{*} 10^{7}$ & 54.9 \\
\hline
\end{tabular}

Table 3. Values of dam-breach parameters used for Lakes Ellsworth

and Lawtonka Dams near Lawton, Oklahoma.

\begin{tabular}{lcc}
\hline $\begin{array}{c}\text { Parameter } \\
\text { estimation equation }\end{array}$ & $\begin{array}{c}\text { Dam-breach- } \\
\text { bottom width, } \\
\text { in feet }\end{array}$ & $\begin{array}{c}\text { Time to full failure, } \\
\text { in hours }\end{array}$ \\
\hline \multicolumn{2}{c}{ Lake Ellsworth Dam } \\
\hline Bureau of Reclamation (1998) & 300 & 3.3 \\
Von Thun and Gillette (1990) & 430 & 2.4 \\
Froeehlich (1995) & 577 & 2.3 \\
Average & 436 & 2.7 \\
\hline
\end{tabular}

Average Lake Lawtonka Dam

Bureau of Reclamation (1998) 300

Von Thun and Gillette $(1990)$

430
510

Froehlich (1995)

Average

413.5

3.3

3.3
1.8

1.8
2.3

2.5
Flood-Inundation Mapping Using Geographic Information Systems

Flood-inundation maps were generated by using HECGeoRAS (Hydrologic Engineering Center, 2011). After each of the models was calibrated and run, the results were exported by using an extensible markup language (XML) script and were subsequently imported into ArcMap. Lidar-derived cross sections were used to generate the flood-inundation maps. All maps were inspected for outlying values and consistency. Areas where other major tributaries flow into East Cache and Medicine Creeks were adjusted to account for backwater to the confluences to match the topographic contour lines equal to the water-surface elevation at the cross section nearest to each confluence.

\section{Flood-Inundation Mapping}

Water-surface profiles for the 75-percent-PMF and sunny-day dam-breach scenarios were developed for both models. Because of the size of the study area, the maps of total flood-inundation areas were subdivided into tiles at a 1:20,000 scale. Maximum floodinundation elevations and times for each bridge for the 75-percentPMF and sunny-day dam-breach scenarios are listed in table 4. For the 75-percent-PMF dam-breach scenario, all bridges in both models were inundated.

Areas such as community-services offices, public works facilities, and parks were located by using shapefiles produced by photography (National Agriculture Imagery Program, 2010) that were plotted on the associated flood-inundation maps. These areas were grouped into four classifications of areas of concern: water treatment plants, wastewater treatment plants, recreational areas, and community-services offices. Each mapped tile of the cross sections and inundated areas are presented in appendixes $1-5$.

(table 1) until there was agreement between the measured stagedischarge relations and the calibrated model.

A sensitivity analysis was performed on the different dam-

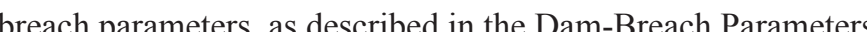
section of this report, as well as on the Manning's roughnss coefficients. Because of the topography of this area, large flat cross sections with relatively steep sides, percent change in total inundated area was not used as the determinant in the Manning's sensitivity analysis. For example, the percent difference in floodinundated area between the 75-percent-PMF dam-breach scenario and the sunny-day dam-breach scenario is less than 12 percent fo the East Cache Creek Basin and 7 percent for the Medicine Creek Basin. For the Manning's sensitivity analysis, the time to peak and peak stage at each of the bridges were determined.

\section{Sources of Uncertainty \\ in Flood-Inundation Maps}

Flood-inundation maps are used to depict areas that may be inundated by water during a dam breach. The uncertainty associated with these maps, which is difficult to measure, may be introduced by errors in topographic or hydraulic data or in the modeling system used to create the flood-inundation map. Data necessary to quantify these errors are seldom available; thus, stringent quality-assurance methods are vital for hydraulic modeling. The methods, procedures, and assumptions used to map the potentially flooded areas, limits of flooding, and flood-wave traveltimes are approximate and should be used as only guidelines for management decisions. Actual areas inundated will depend on the actual failure mechanism during (Federal Energy Regulatory Commission, 2007). flood conditions and may differ from the areas shown on the maps
Table 4. Maximum flood-inundation elevation and time for 75-percent probable maximum flood (PMF) and sunny-day dam-breach scenarios for .

[ID, identifier, hh:mm, hours and minutes]

\begin{tabular}{|c|c|c|c|c|c|}
\hline Bridge name & Cross section ID' & $\begin{array}{c}\text { 75-percent PMF stage, } \\
\text { in feet }\end{array}$ & $\begin{array}{c}\text { 75-percent PMF stage, } \\
\text { in hh:mm }\end{array}$ & $\begin{array}{c}\text { Sunny-day stage, } \\
\text { in feet }\end{array}$ & $\begin{array}{c}\text { Sunny-day stage, } \\
\text { in hh:mm }\end{array}$ \\
\hline \multicolumn{6}{|c|}{ Lake Ellsworth on East Cache Creek } \\
\hline Highway 277 & 348313.5 & $1,201.90$ & $02: 55$ & $1,192.48$ & 03:45 \\
\hline Glover Road & 338271.3 & $1,188.29$ & 03:10 & $1,181.08$ & 04:10 \\
\hline Interstate 44 & 310843.5 & $1,161.74$ & 03:35 & $1,153.57$ & 05:30 \\
\hline Lake Road & 306638 & $1,150.29$ & 04:10 & $1,144.21$ & 06:05 \\
\hline Qinette Road & 281490.8 & $1,137.71$ & 05:00 & $1,130.26$ & $07: 55$ \\
\hline Hoyle Road & 271344.3 & $1,128.67$ & 05:30 & $1,121.26$ & 09:05 \\
\hline Rogers Road & 249251 & $1,106.21$ & 06:20 & $1,099.52$ & 10:35 \\
\hline Gore Road & 228809.9 & $1,092.75$ & $06: 50$ & $1,088.19$ & $11: 55$ \\
\hline Lee Boulevard & 223404.4 & $1,082.19$ & 07:10 & $1,079.11$ & 12:05 \\
\hline Bishop Road & 215171.8 & $1,072.17$ & 07:35 & $1,066.99$ & 12:50 \\
\hline Coombs Road & 207588.3 & $1,065.05$ & 08:00 & $1,059.70$ & 13:35 \\
\hline Tinney Road & 177428.1 & $1,047.95$ & 09:20 & $1,042.24$ & $16: 00$ \\
\hline County Road 1750 & 131670 & $1,027.87$ & 10:45 & $1,021.70$ & 18:55 \\
\hline County Road 1770 & 98970.55 & $1,016.12$ & 11:40 & $1,008.84$ & 20:50 \\
\hline County Road 2620 & 41468.84 & 991.44 & 14:15 & 984.25 & $25: 25$ \\
\hline Highway 53 & 15497.69 & 981.23 & $15: 10$ & 973.15 & 28:30 \\
\hline \multicolumn{6}{|c|}{ Lake Lawtonka on Medicine Creek } \\
\hline Medicine Foot Bridge & 335375.5 & $1,303.48$ & $02: 21$ & $1,297.96$ & $02: 24$ \\
\hline Medicine Wooden Bridge & 334434.3 & $1,295.82$ & $02: 25$ & $1,291.18$ & $02: 28$ \\
\hline Highway 49 & 332508.8 & $1,289.30$ & $02: 36$ & $1,284.66$ & $02: 38$ \\
\hline White Wolf Road & 286100 & $1,152.90$ & $06: 47$ & $1,147.57$ & 08:16 \\
\hline Medicine Quinette Road & 281821.7 & $1,131.28$ & $07: 25$ & $1,129.16$ & $07: 58$ \\
\hline Interstate 44 & 277190.6 & $1,126.71$ & 08:09 & $1,124.46$ & 08:48 \\
\hline Railroad Bridge & 277023.4 & $1,126.18$ & $08: 16$ & $1,123.85$ & 08:58 \\
\hline Hoyle Road & 271344.3 & $1,122.61$ & 08:44 & $1,120.42$ & $09: 42$ \\
\hline Rogers Road & 249251 & $1,102.28$ & 09:46 & $1,099.45$ & 01:02 \\
\hline Gore Road & 228809.9 & $1,090.19$ & $10: 31$ & $1,087.96$ & $12: 28$ \\
\hline Lee Boulevard & 223404.4 & $1,080.33$ & $10: 49$ & $1,079.08$ & $12: 38$ \\
\hline Bishop Road & 215168.16 & $1,069.06$ & $11: 22$ & $1,066.75$ & 13:27 \\
\hline Coombs Road & 207587.88 & $1,061.83$ & $11: 57$ & $1,059.37$ & 14:11 \\
\hline Tinney Road & 177428.1 & $1,044.29$ & $13: 56$ & $1,041.74$ & $16: 34$ \\
\hline County Road 1750 & 131670 & $1,023.80$ & $16: 13$ & $1,020.95$ & 19:39 \\
\hline County Road 1770 & 98970.55 & $1,011.23$ & $17: 41$ & $1,007.81$ & 21:39 \\
\hline County Road 2620 & 41468.84 & 986.02 & 21:17 & 983.16 & $25: 53$ \\
\hline Highway 53 & 15497.69 & 975.41 & $23: 21$ & 971.74 & 29:32 \\
\hline
\end{tabular}


Dam-Breach Analysis and Flood-Inundation Mapping for Lakes Ellsworth and Lawtonka near Lawton, Oklahom

\section{Topographic Uncertainties}

Elevation data composed the primary dataset for creating ater-surface and shoreline maps. The elevation data for this study were obtained by using lidar techniques. Because of the flat terrain in the downstream sections of the study area, relatively large errors in water-surface extent can occur from a small error in watersurface elevation, as described by a simple calculation: if a river reach has a slope of 0.1 percent, a 1 -inch difference in elevation can yield about an 80-ft difference in horizontal distance of inundated area. It is difficult, therefore, to determine the extents of flooding with a high degree of accuracy (Bales and Wagner, 2009).

\section{Manning's n-Value Uncertainties}

Manning's roughness coefficients can affect not only the extent of a flood-inundation area but also the timing of a flood peak. Although the Manning's roughness coefficients used in this study were supported by previously calibrated models, changes in the flood-plain hydraulics over time may decrease accuracy. A sensitivity analysis was conducted for the PMF scenarios of each of the models. In this sensitivity analysis the Manning's roughness coefficient $n$-values were tested at 0.9 and 1.1 times the modeled values. These changes in the Manning's roughness coefficient n-values produced very little change in total inundated area but did result in changes in the peak water-surface elevations up to about $4 \mathrm{ft}$ different from the calibrated PMF scenario and changes in the timing of flood peaks of up to approximately 1.25 hours. Table 5 shows the peak water-surface elevation at each of the bridges, as well as the time to peak, for the PMF sensitivity models.

\section{Model Limitations}

The major data inputs for the HEC-RAS model are topographic data, Manning's roughness coefficient n-values, bridg geometry data, and initial flow and boundary conditions. Errors can be associated with each of those data types. The major cause of uncertainty in this model, however, is the one-dimensional assumption that the hydraulic variables such as water-surface elevation are constant across each computational node (cross section). In an extremely flat flood plain such as this study area, the one-dimensional assumption may not be valid. For example, although the flow in the mair certain elevation, other streams that are intersected by the give cross section may not be at the same water-surface elevation. Two-dimensional models can be used to account for this type of error. Horritt and Bates (2001) demonstrated that increased lateral resolution of a two-dimensional model allows for a better simulation of the water storage in a flood plain.

[ID, identifier; hh:mm, hours and minutes]
Table 5. Peak water-surface elevation and time to peak for the sensitivity analysis of Manning's roughness coefficients for the 75-percent aros for Lakes Ellsworth and Lawtonka near Lawton, Oklahoma.

\begin{tabular}{|c|c|c|c|c|c|c|c|}
\hline Bridge name & $\begin{array}{c}\text { Cross } \\
\text { section ID' }\end{array}$ & $\begin{array}{c}\text { PMF stage, } \\
\text { in feet }\end{array}$ & $\begin{array}{l}\text { PMF stage, } \\
\text { in hh:mm }\end{array}$ & $\begin{array}{l}0.9 \text { Manning's } \\
\text { stage, in feet }\end{array}$ & $\begin{array}{l}0.9 \text { Manning's } \\
\text { stage, in hh:mm }\end{array}$ & $\begin{array}{l}1.1 \text { Manning's } \\
\text { stage, in feet }\end{array}$ & $\begin{array}{c}1.1 \text { Manning's } \\
\text { stage, in hh:mm }\end{array}$ \\
\hline \multicolumn{8}{|c|}{ Lake Ellsworth on East Cache Creek } \\
\hline Highway 277 & 348313.5 & $1,198.12$ & $02: 52$ & $1,197.24$ & $02: 51$ & $1,198.99$ & $02: 53$ \\
\hline Glover Road & 338271.3 & $1,184.68$ & 03:00 & $1,184.04$ & $02: 58$ & $1,185.28$ & 03:02 \\
\hline Interstate 44 & 310843.5 & $1,164.02$ & 03:10 & $1,164.41$ & 03:15 & $1,165.66$ & 03:23 \\
\hline Lake Road & 306638 & $1,146.24$ & 03:46 & $1,145.57$ & $03: 43$ & $1,146.76$ & 03:58 \\
\hline Qinette Road & 281490.8 & $1,134.32$ & $04: 23$ & $1,133.84$ & 04:24 & $1,135.18$ & 04:37 \\
\hline Hoyle Road & 271344.3 & $1,124.51$ & 04:51 & $1,123.85$ & 04:50 & $1,124.97$ & 05:04 \\
\hline Rogers Road & 249251 & $1,102.13$ & $05: 22$ & $1,106.01$ & $04: 56$ & $1,102.60$ & 05:41 \\
\hline Gore Road & 228809.9 & $1,090.93$ & $05: 48$ & $1,090.77$ & $05: 36$ & $1,091.01$ & 06:09 \\
\hline Lee Boulevard & 223404.4 & $1,080.29$ & 05:58 & $1,080.18$ & $05: 45$ & $1,080.37$ & $06: 22$ \\
\hline Bishop Road & 215171.8 & $1,068.61$ & 06:13 & $1,068.14$ & 05:59 & $1,069.01$ & $06: 38$ \\
\hline Coombs Road & 207588.3 & $1,061.33$ & 06:29 & $1,060.85$ & $06: 13$ & $1,061.74$ & $06: 56$ \\
\hline Tinney Road & 177428.1 & $1,043.84$ & 07:26 & $1,043.20$ & 07:04 & $1,044.40$ & $07: 56$ \\
\hline County Road 1750 & 131670 & $1,025.09$ & $08: 23$ & $1,024.52$ & 07:59 & $1,025.62$ & 08:57 \\
\hline County Road 1770 & 98970.55 & $1,011.74$ & 09:01 & $1,011.15$ & 08:33 & $1,012.29$ & $09: 37$ \\
\hline County Road 2620 & 41468.84 & 989.09 & $10: 40$ & 988.46 & 10:07 & 989.67 & $11: 20$ \\
\hline Highway 53 & 15497.69 & 979.97 & 11:11 & 979.88 & 10:37 & 980.18 & $11: 52$ \\
\hline \multicolumn{8}{|c|}{ Lake Lawtonka on Medicine Creek } \\
\hline Medicine Foot Bridge & 335375.5 & $1,303.48$ & $02: 21$ & $1,301.54$ & $02: 23$ & $1,304.88$ & 02:22 \\
\hline Medicine Wooden Bridge & 334434.3 & $1,295.82$ & $02: 25$ & $1,294.04$ & 02:24 & $1,297.44$ & 02:26 \\
\hline Highway 49 & 332508.8 & $1,289.30$ & $02: 36$ & $1,287.79$ & 02:34 & $1,290.49$ & 02:36 \\
\hline White Wolf Road & 286100 & $1,152.90$ & $06: 47$ & $1,148.70$ & $05: 47$ & $1,152.57$ & 07:06 \\
\hline Medicine Quinette Road & 281821.7 & $1,131.28$ & $07: 25$ & $1,131.25$ & $06: 23$ & $1,131.68$ & $07: 49$ \\
\hline Interstate 44 & 277190.6 & $1,126.71$ & 08:09 & $1,126.63$ & 07:04 & $1,127.10$ & $08: 35$ \\
\hline Railroad Bridge & 277023.4 & $1,126.18$ & 08:16 & $1,126.11$ & 07:11 & $1,126.58$ & $08: 42$ \\
\hline Hoyle Road & 271344.3 & $1,122.61$ & 08:44 & $1,122.46$ & 07:37 & $1,123.01$ & 09:12 \\
\hline Rogers Road & 249251 & $1,102.28$ & $09: 46$ & $1,102.17$ & 08:34 & $1,102.64$ & 10:19 \\
\hline Gore Road & 228809.9 & $1,090.19$ & 10:31 & $1,090.27$ & $09: 15$ & $1,090.22$ & 11:10 \\
\hline Lee Boulevard & 223404.4 & $1,080.33$ & 10:49 & $1,080.38$ & $09: 28$ & $1,080.34$ & $11: 28$ \\
\hline Bishop Road & 215168.16 & $1,069.06$ & $11: 22$ & $1,068.87$ & 10:01 & $1,069.16$ & 12:06 \\
\hline Coombs Road & 207587.88 & $1,061.83$ & $11: 57$ & $1,061.64$ & $10: 33$ & $1,062.13$ & $12: 43$ \\
\hline Tinney Road & 177428.1 & $1,044.29$ & 13:56 & $1,044.00$ & $12: 27$ & $1,044.60$ & $14: 52$ \\
\hline County Road 1750 & 131670 & $1,023.80$ & 16:13 & $1,023.54$ & $14: 32$ & $1,024.03$ & $17: 23$ \\
\hline County Road 1770 & 98970.55 & $1,011.23$ & $17: 41$ & $1,010.94$ & $15: 53$ & $1,011.47$ & 18:59 \\
\hline County Road 2620 & 41468.84 & 986.02 & 21:17 & 985.79 & 19:06 & 986.19 & $22: 55$ \\
\hline Highway 53 & 15497.69 & 975.41 & $23: 21$ & 775.72 & 21:10 & 975.18 & $25 \cdot 08$ \\
\hline
\end{tabular}

\section{Summary and Conclusions}

This report presents results of a cooperative study by the city of Lawton, Oklahoma, and the U.S. Geological Survey (USGS) to model dam-breach scenarios at Lakes Ellsworth and Lawtonka, near Lawton, and to map the potentially resulting flood-inundation areas. Lake Ellsworth, constructed between 1959 and 1961, provides secondary water storage for the city of Lawton, as well as for flood control and recreation. Lake Lawtonka, constructed in 1907, serves as the primary water storage for the city of Lawton. The Lake Ellsworth Dam and Lake Lawtonka Dam are classified by the State of Oklahoma as a high-hazard dams and therefore need to have flood-inundation maps modeled as part of the emergency action plans required by the Oklahoma Water Resources Board.

For this report, flood profiles for a 75-percent probable maximum flood (PMF) dam breach and a sunny-day dam breach were computed for the stream reach downstream from the Lake Ellsworth Dam and the Lake Lawtonka Dam by means of a one-dimensional dynamic (unsteady-flow) model using the U.S. Army Corps of Engineers Hydrologic Engineering Center's River Analysis System (HEC-RAS) software. Development of accurate hydraulic models requires accurate land-surface elevation data. Light detection and ranging (lidar) data were used to develop a high-resolution digital elevation model and a 1-foot contour elevation map for the flood plain below Lakes Ellsworth and Lawtonka. Additional topographic data were collected by use of a U.S. Survey-grade real-time kinematic Global Positioning System receiver. Field measurements of bridge dimensions were determined at all locations in the study area. Streamflows and water-level data from a USGS streamflow-gaging station, East Cache Creek near Walters, Okla. (07311000), were used as hydrologic inputs for the model to help quantify the sunny-day dam-breach scenario.

The resulting flood-inundation maps were generated by HEC-GeoRAS (a tool box for ArcGISTM [Environmental Systems Research Institute, Inc.]) and imported into a geographic information system to delineate areas flooded in each flood scenario. Some areas of concern near the city of Lawton, if a dam breach occurs at the Lake Ellsworth Dam or the Lake Lawtonka Dam, included water treatment plants, wastewater treatment plants, recreational areas, and community-services offices.

Uncertainty may be introduced into flood-inundation maps with regards to the accuracy of the topographic, hydraulic, and hydrologic data and the modeling system used. Even with uncertainties, the produced dam-breach models and flood-inundation maps can provide city managers, emergency management personnel, and residents in the East Cache River Basin with vital information for flood-response activities if a dam breach occurs at the Lake Ellsworth Dam or the Lake Lawtonka Dam. 


\section{References Cited}

Arcement, G.J., and Schneider V.R., 1989, Guide for selecting flood plains: U.S. Geological Survey Water-Supply Paper 2339 [variously paged].

Arthur, H.G., 1977, Teton Dam failure. The evaluation of dam safety: New York, Engineering Foundation Conference Proceedings,

Bales, J.D., and Wagner, C.R., 2009, Sources of uncertainty in flood inundation maps: Journal of Flood Risk Management, v. 2,

Barnes, H.H., 1967, Roughness characteristics of natural channels: U.S. Geological Survey Water-Supply Paper 1849 [variously paged].

Bureau of Reclamation, 1988, Downstream hazard classification guidelines: Denver Colo., U.S. Department of the Interior, Bureau of Reclamation, ACER Technical Memorandum No. 11, 57 p.

Bureau of Reclamation, 1996, Cache Creek Project-Hydraulic analysis of Cache and East Cache Cre
Plains Regional Office, p. 7-8.

CH2MHILL, 2000, Evaluation of alternative gate operations at Lake Ellsworth and Lake Lawtonka: City of Lawton, Okla., p. 13-14.

Collier, Michael, Webb, R.H., and Schmidt, J.C., 1996, Dams and rivers - Primer on the downstream effects of dams: U.S. Geological

Coon, W.F., 1998, Estimation of roughness coefficients of natural strean channels with vegetated banks: U.S Geological Survey Water-Supply Paper 2441 [variously paged]

Davies, W.E., Bailey, J.F., and Kelly, D.B, 1972, West Virginia's Buffalo Creek flood - A study of the hydrology and engineering geology: U.S. Geological Survey Circular 667, 32 p.

Environmental Systems Research Institute, 2011, ArcGIS help: Redlands, Calif,, accessed April 1, 2011, at http://webhelp.esri.com/ (a)

Federal Emergency Management Agency, 1998, Federal guidelines for dam safety: U.S. Department of Homeland Secur
Emergency Management Agency [variously paged].

Federal Energy Regulatory Commission, 2007, Engineering guidelines for the evaluation of hydropower projects, emergency action plans: accessed Auprelin 1, 2011, at http:///www.ererc.gov/industrties]

Froehlich, D.C., 1995, Embankment dam breach parameters revisited: New York, Water Resources Engineering Proceedings, 1995 American Society of Civil Engineers Conference on Water Resource

Horritt, M.S., and Bates, P.D., 2001, Effects of spatial resolution on a raster based model of flood flow: Journal of Hydrology, v.

Hydrologic Engineering Center, 2010a, HEC-RAS River Analysis System user' 's manual, version 4.1: Davis, Calif., accessed April 1,

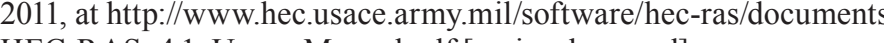
HEC-RAS 4.1 Users _Manual.pdf [variously paged]
Hydrologic Engineering Center, 2010b, HEC-RAS River Analysis System hydraulic reference manual, version 4.1: Davis, Calif

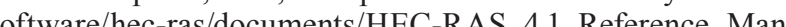
pdf [variously paged].

Hydrologic Engineering Center, 2011, HEC-GeoRAS GIS tools Calif., accessed April 1, 2011, at http:///wwwhecusucace army mil/ software/hec-ras/documents/HEC-GeoRAS_43 Users_Manual.pd [variously paged].

Lewis, J.M., and Esralew, R.A., 2009, Statistical summaries of streamflow in and near Oklahoma through 2007: U.S. Geological
Survey Scientific Investigations Report 2009-5135, p. 456-459.

Multi-Resolution Land Characteristics Consortium, 2008, 2001 National Land Cover Database (NLCD), accessed April 1, 2011, at http://www.

National Agriculture Imagery Program, 2010, NAIP imagery, accessed June 1, 2011, at http://www.fsa.usda.gov/FSA/apfoapp?area=home\&s

National Digital Elevation Program, 2004, Guidelines for digital elevation data, version 1.0: National Digital Elevation Program [variously paged].

National Geodetic Survey, 2011, Continuously Operating Reference
Station (CORS): National Geodetic Survey, acessed April 1, 2011, http://www.ngs.noaa.gov/CORS

Oklahoma Water Resources Board, 2005, Hydrographic survey of Ellsworth Lake: Oklahoma Water Resources Board, p. 4-9. Oklahoma Water Resources Board, 2006, Hydrographic survey of Lake
Lawtonka: Oklahoma Water Resources Board, p. 4-9.

Oklahoma Water Resources Board, 2011, Hydrologic and hydraulic guidelines for dams in Oklahoma: Oklahoma Water Resources Geo-Strata, v. 6, issue 2, March/April 2006, p. 14-17.

Trimble Navigation Limited, 2003, Trimble R7/R8 GPS receiver user guide, version 1.00, revision A: Sunnyvale, Calif., Trimble Navigation

Trimble Navigation Limited, 2005, Trimble Geomatics Office, versio 1.63, build 10: Sunnyvale, Calif., Trimble Navigation Limit

U.S. Geological Survey, 2010, USGS water data for the Nation: Nationa Water Information System (NWISWeb), accessed June 1, 2011, at

U.S. Geological Survey, 2011, National Elevation Dataset: U.S. Geological Survey, accessed on June 1, 2011, at http://ned.usgs.gov/ Von Thun, J.L., and Gillette, D.R., 1990, Guidance on breach parameters, Denver, Colo, Internal Memorandum, U.S. Department eau of Reclamation, p. 17

Williams, W., 2010, Project plan Lawton, OK dam breach: Chesterfield, Mo., Surdex Corporation, p. 2-9.

Williams, W., 2011, Lidar accuracy report, OK dam breach: Chesterfield, Mo., Surdex Corporation, p. 2-4.

\section{Appendixes 1-5}

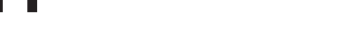





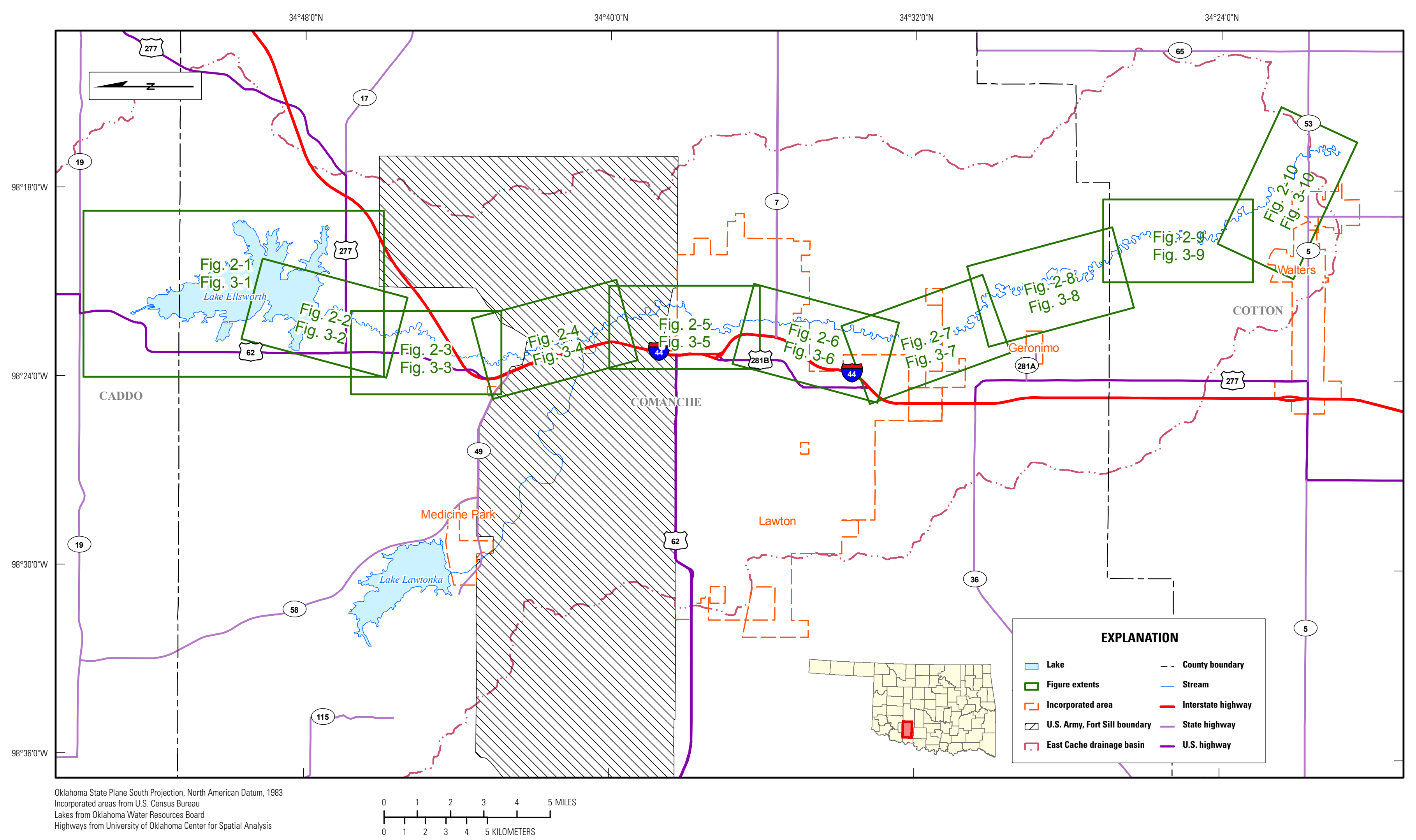




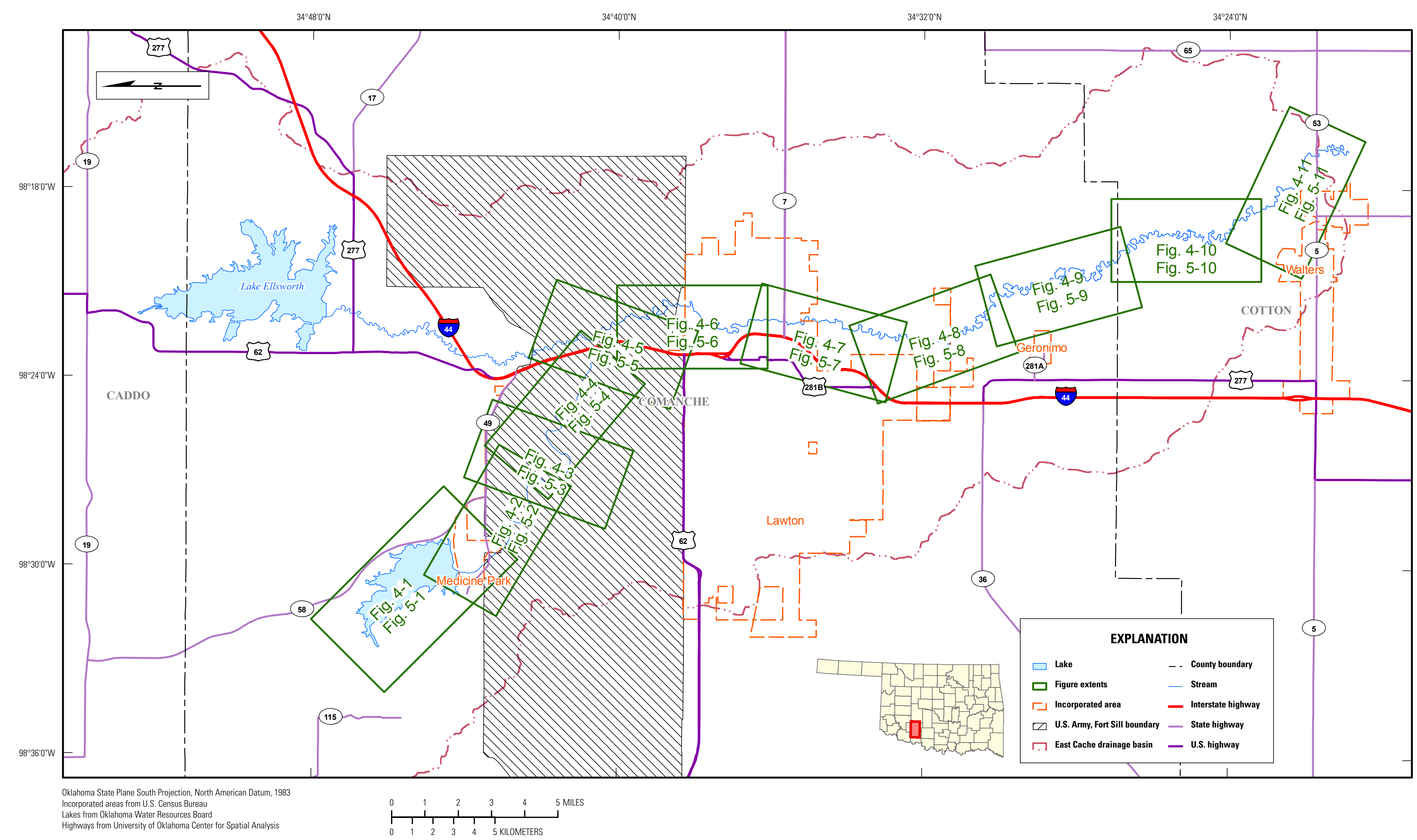

Figure 1-2. Map extents for figures in appendixes 4 and 5 for the dam-breach analysis and flood-inundation mapping for Lakes Ellsworth and Lawtonka near Lawton, 0klahoma. 


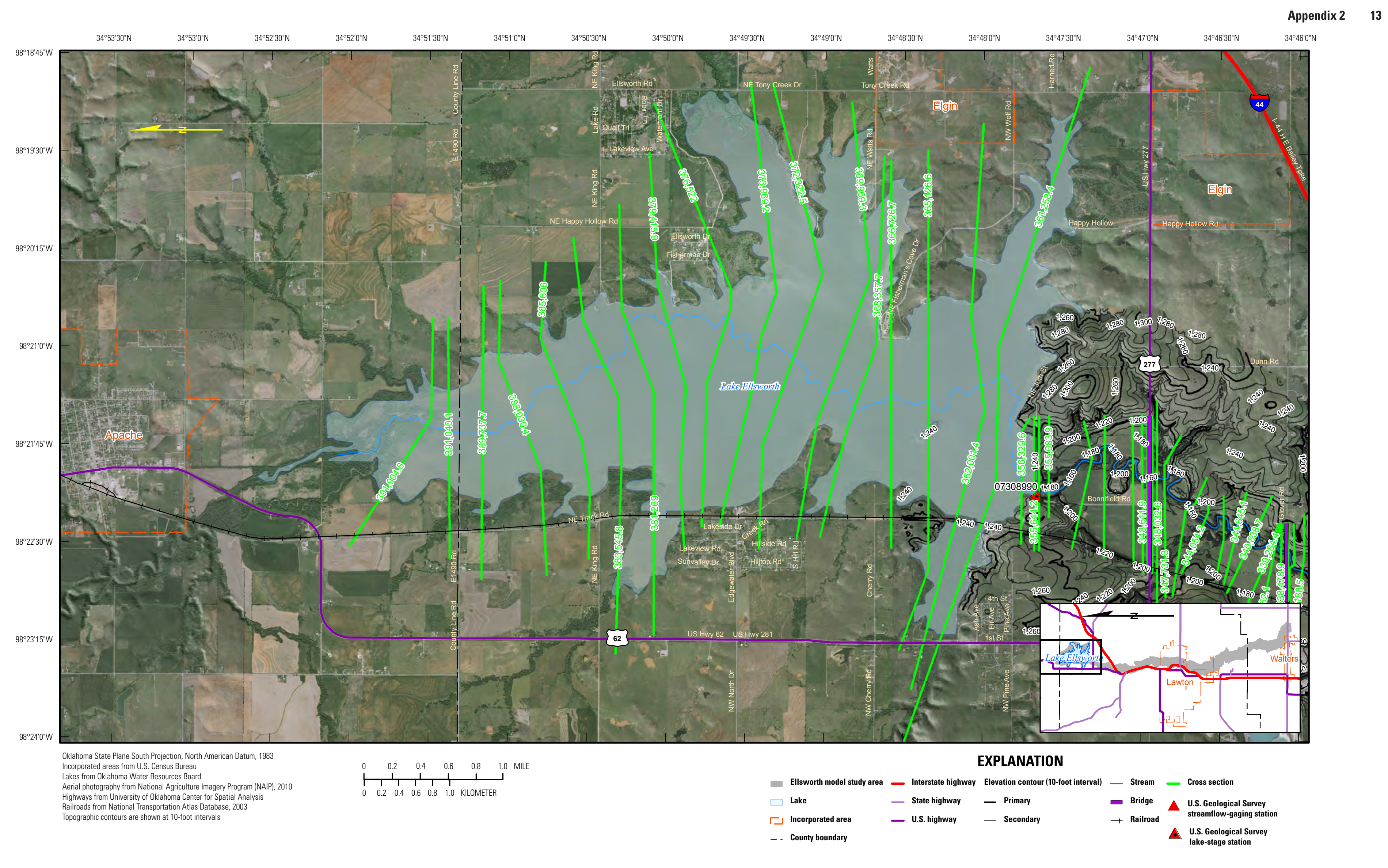

Figure 2-1. Cross-section locations for Lake Ellsworth, near Lawton, Oklahoma, for the Hydrologic Engineering Center's River Analysis System (HEC-RAS) model (Hydrologic Engineering Center, 2010a). 
14 Dam-Breach Analysis and Flood-Inundation Mapping for Lakes Ellsworth and Lawtonka near Lawton, Oklahoma
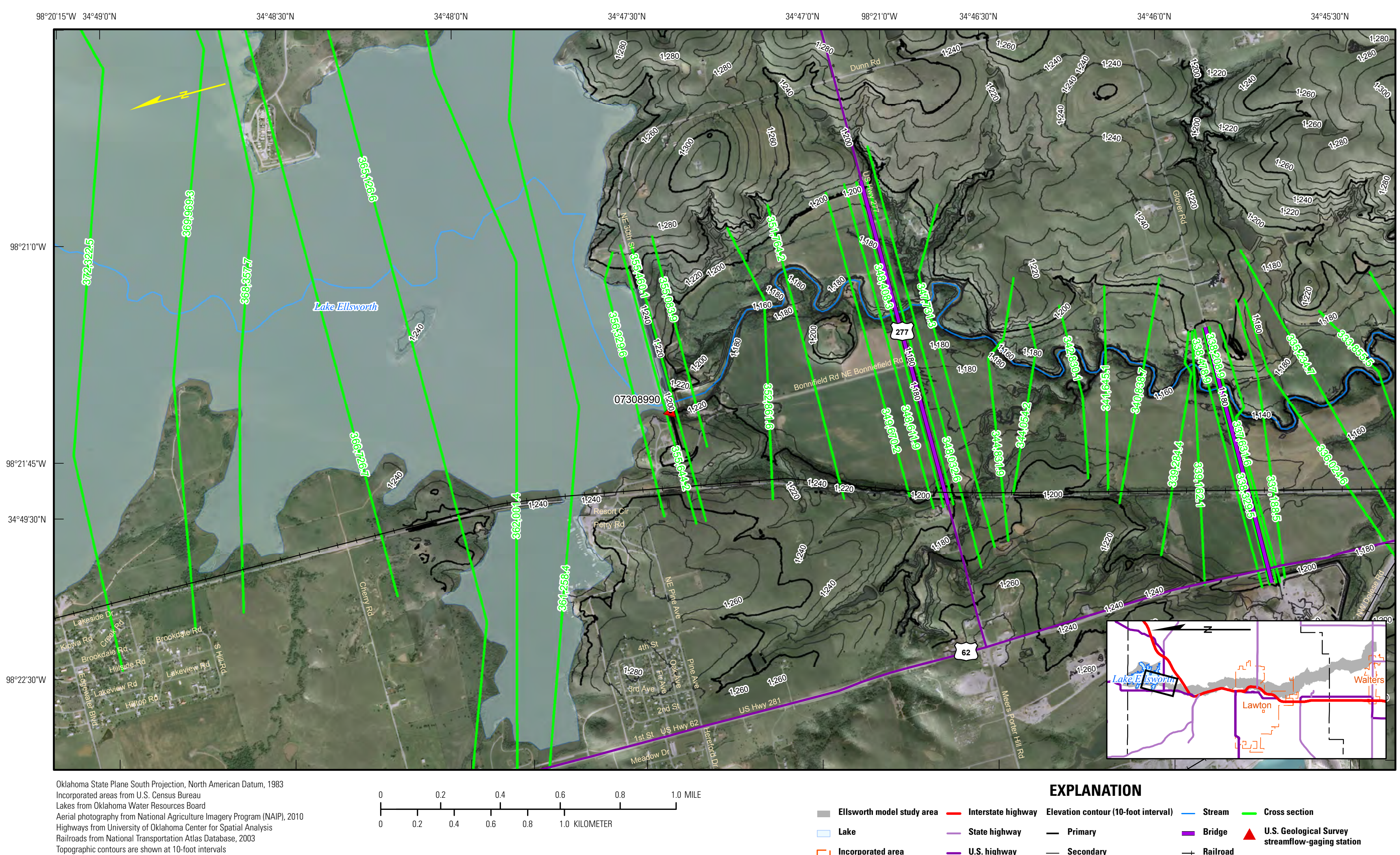
Railroads from National Iransportation Altas Database, 2003
Topographic contours are shown at 10 - 00 tot interals

Figure 2-2. Cross-section locations for Lake Ellsworth, near Lawton, Oklahoma, for the Hydrologic Engineering Center's River Analysis System (HEC-RAS) model (Hydrologic Engineering Center, 2010a).

EXPLANATION

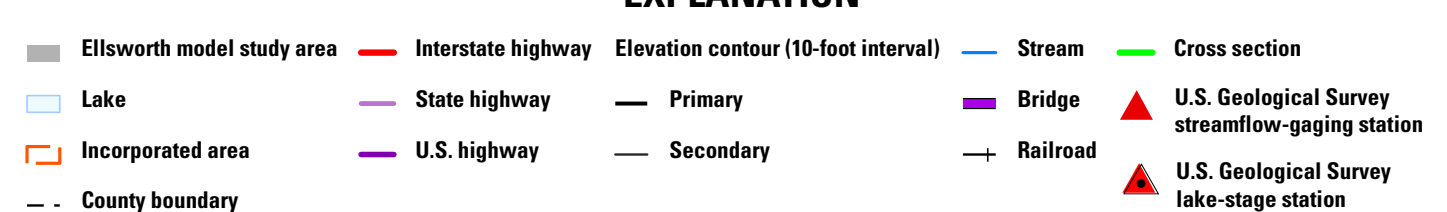




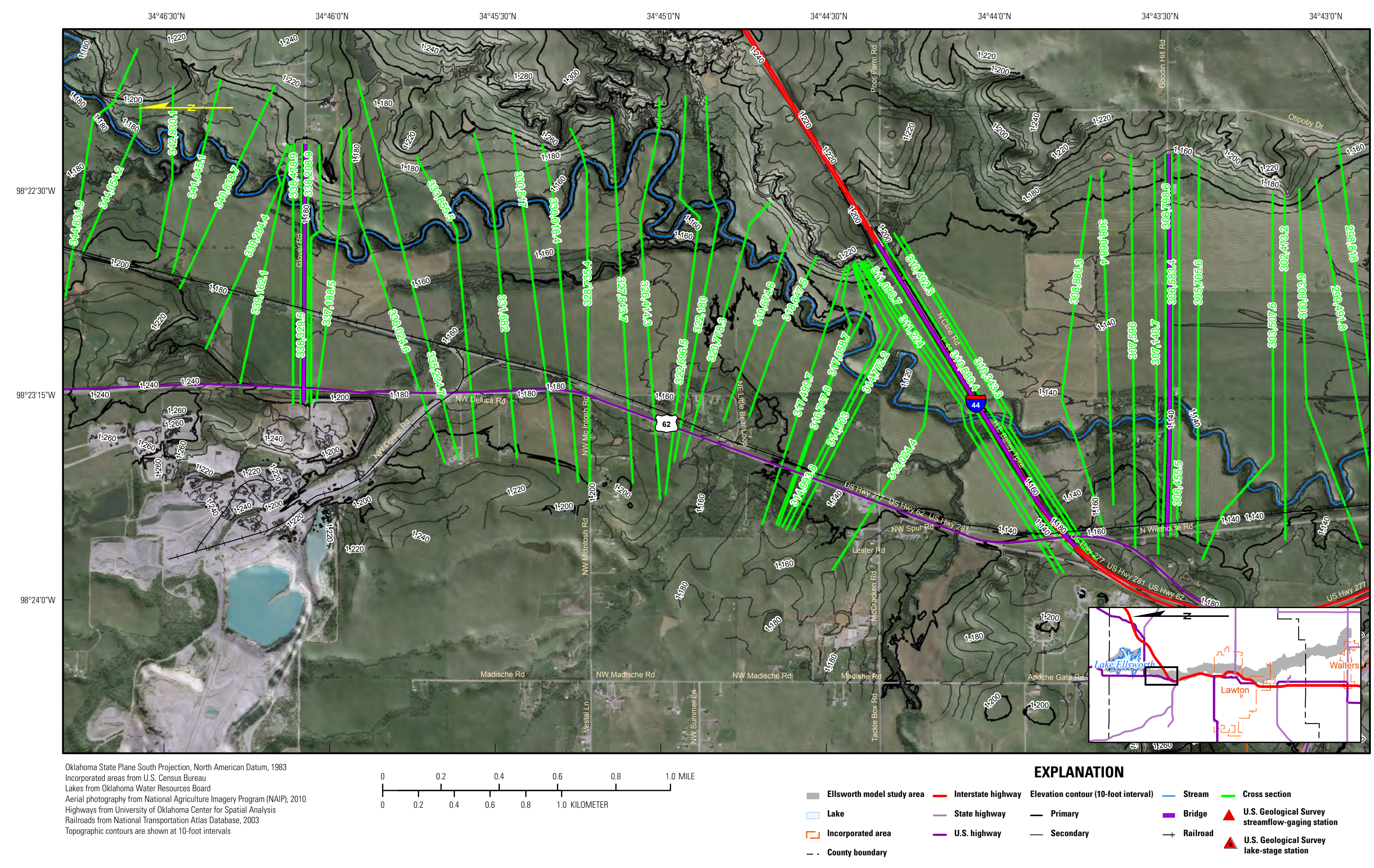

Figure 2-3. Cross-section locations for Lake Ellsworth, near Lawton, Oklahoma, for the Hydrologic Engineering Center's River Analysis System (HEC-RAS) model (Hydrologic Engineering Center, 2010a). 


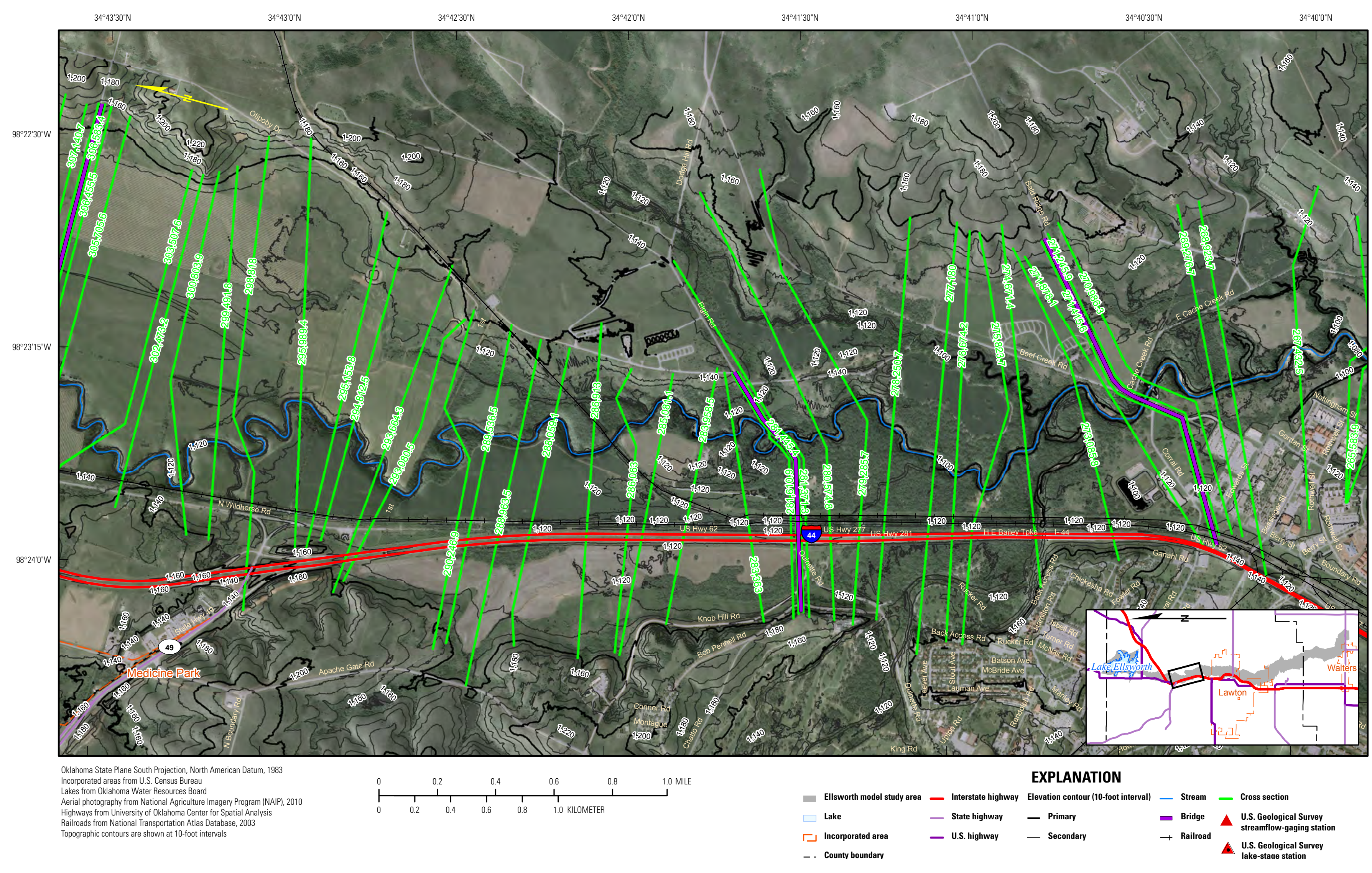




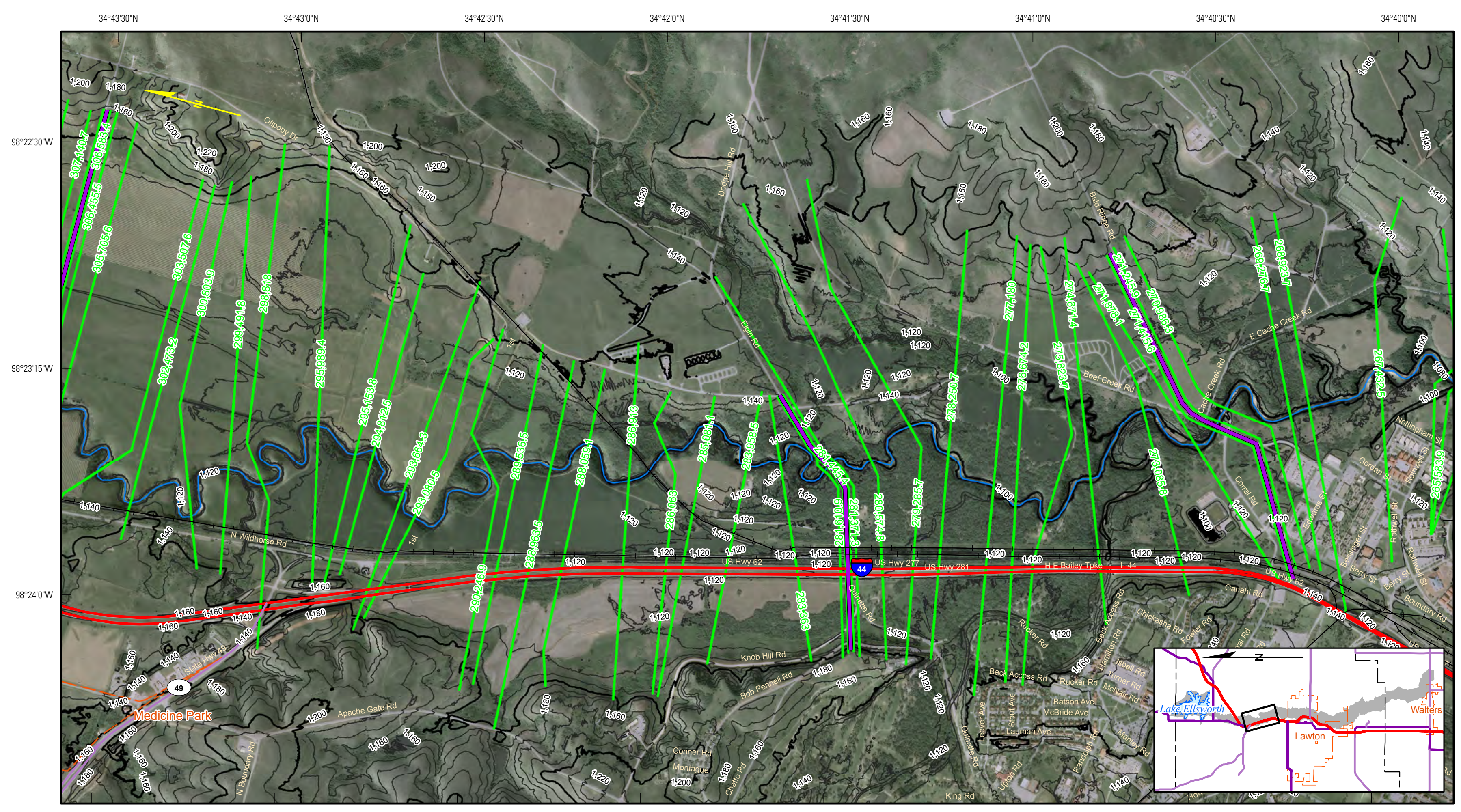

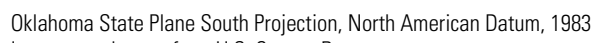

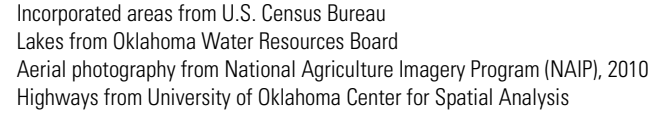

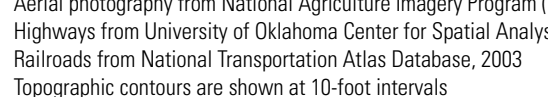

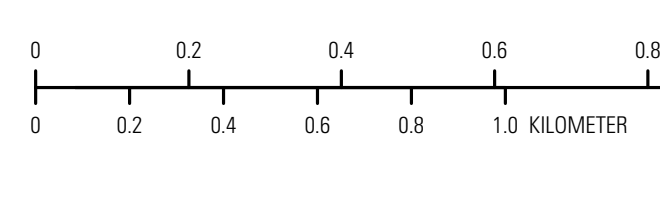

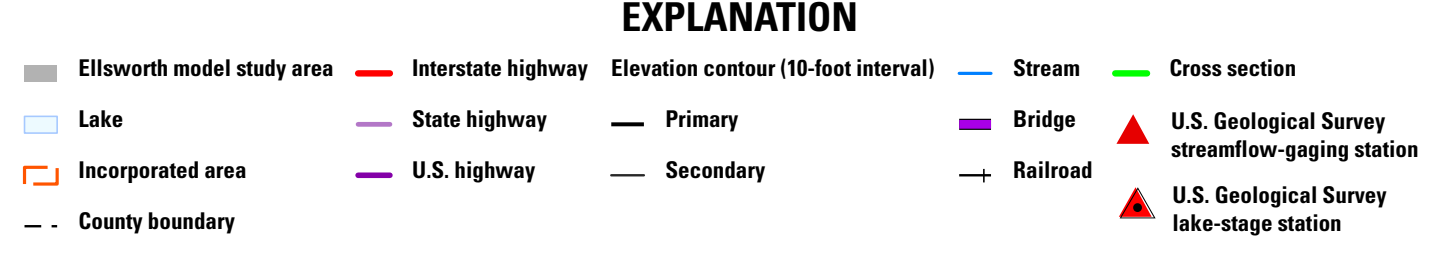


18 Dam-Breach Analysis and Flood-Inundation Mapping for Lakes Ellsworth and Lawtonka near Lawton, Oklahoma

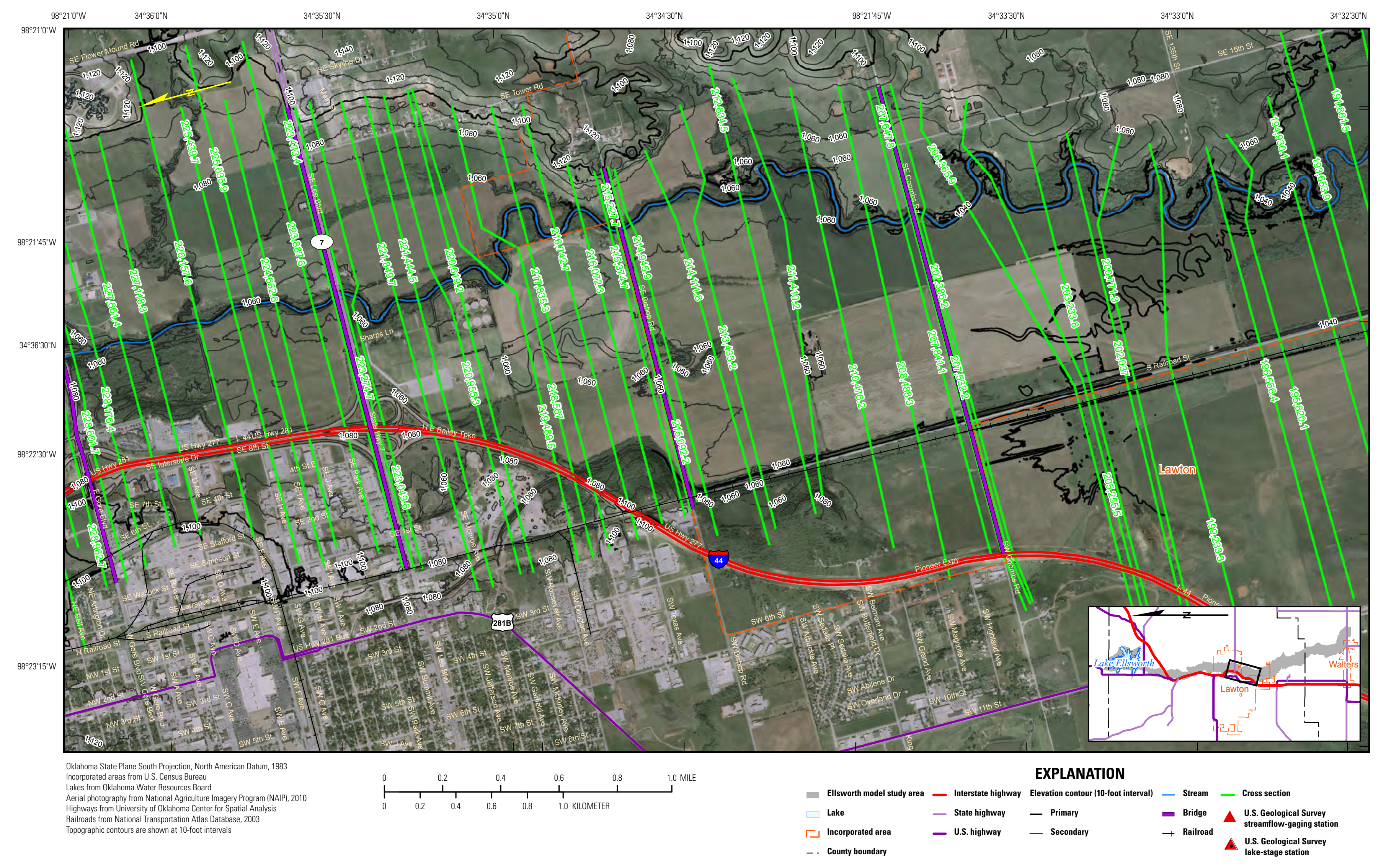

Figure 2-6. Cross-section locations for Lake Ellsworth, near Lawton, 0klahoma, for the Hydrologic Engineering Center's River Analysis System (HEC-RAS) model (Hydrologic Engineering Center, 2010a). 


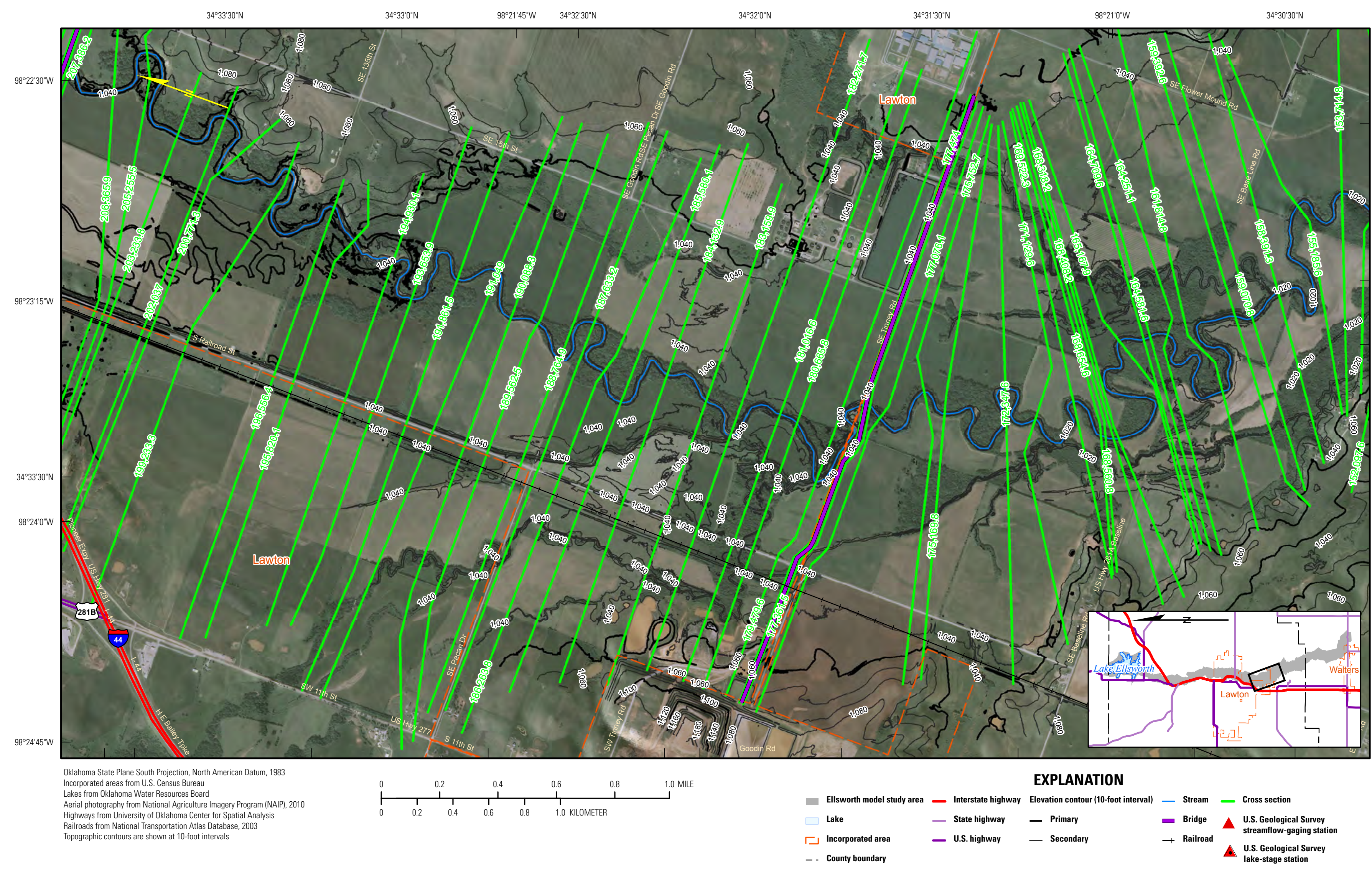


20 Dam-Breach Analysis and Flood-Inundation Mapping for Lakes Ellsworth and Lawtonka near Lawton, Oklahoma

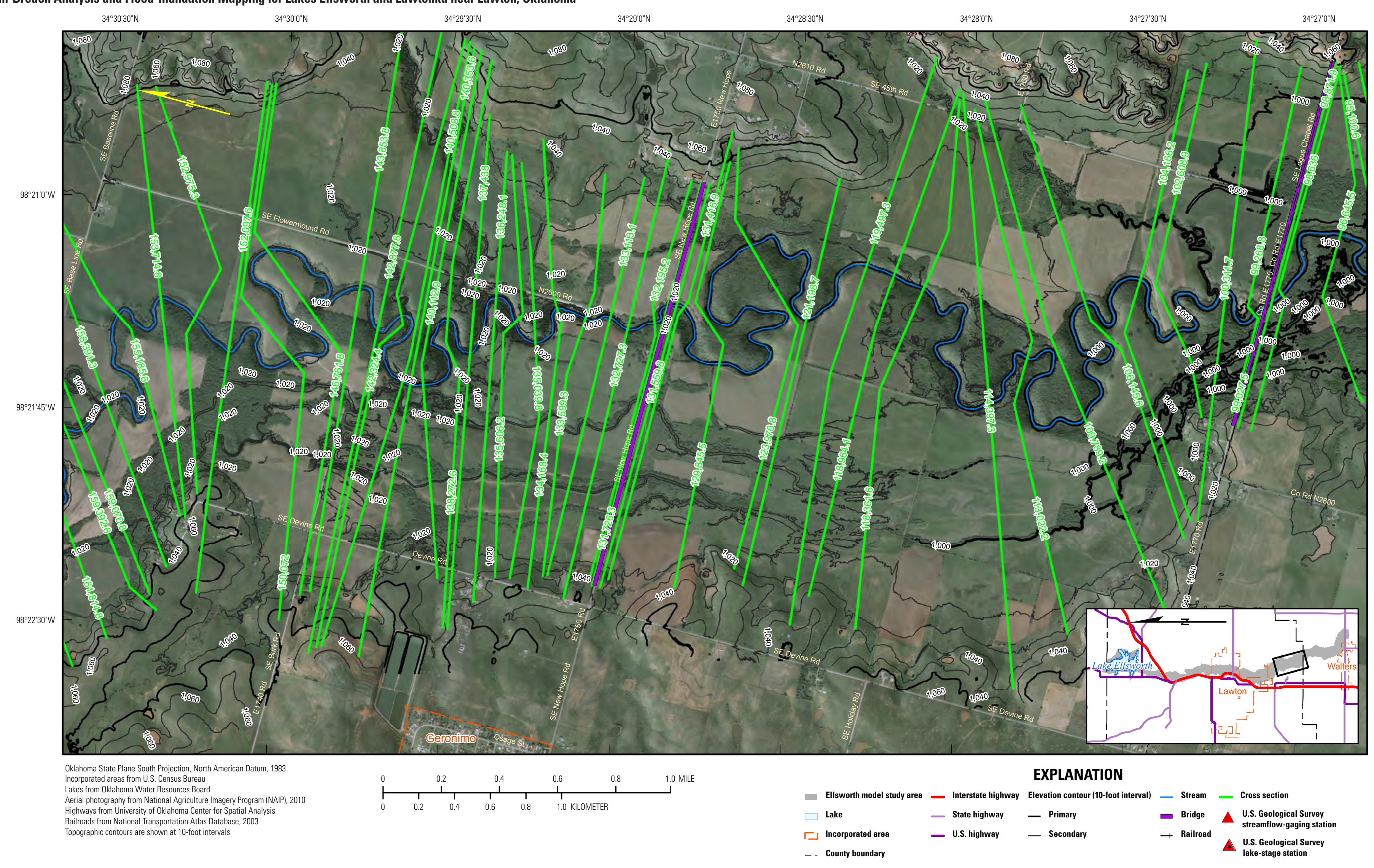




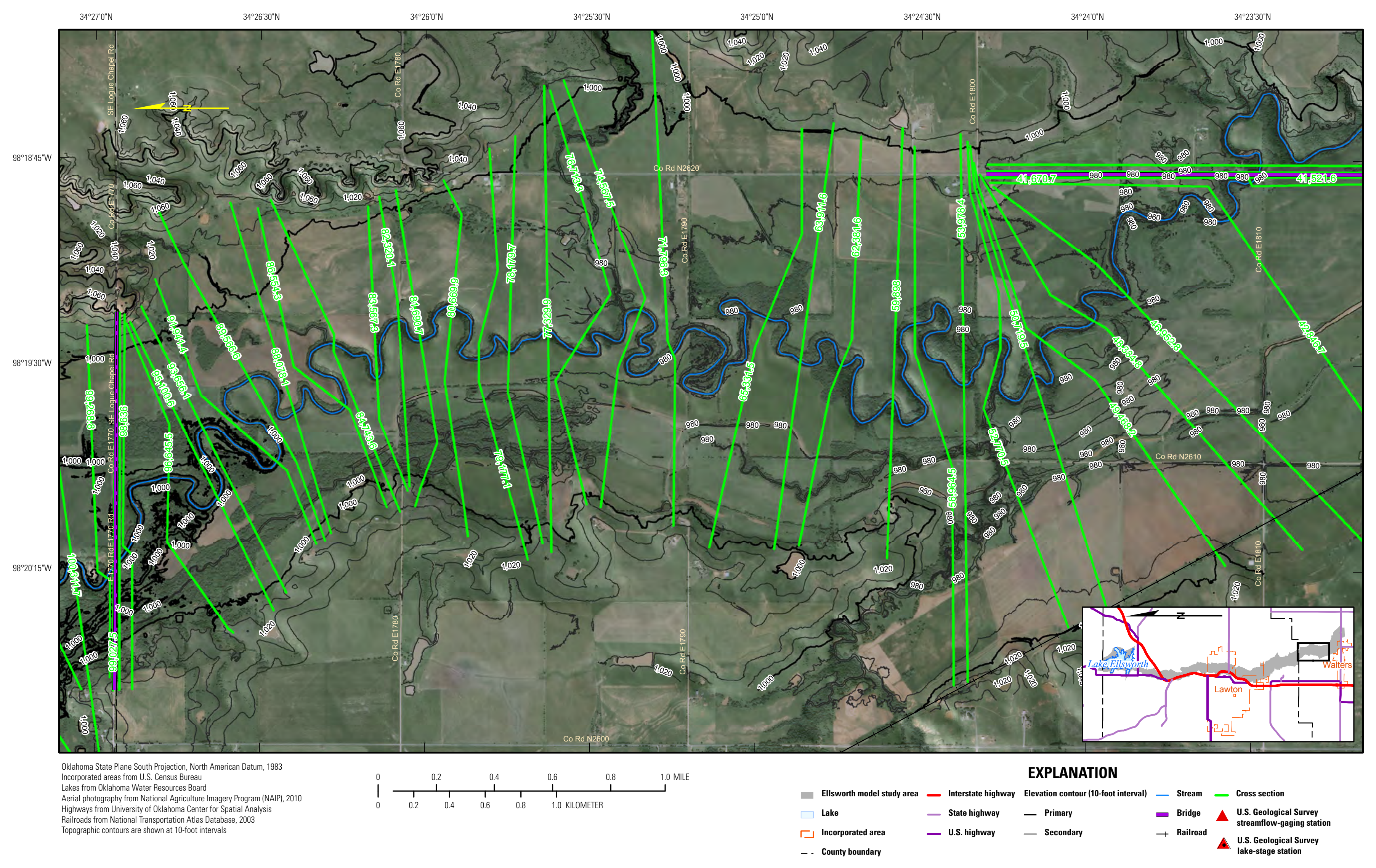




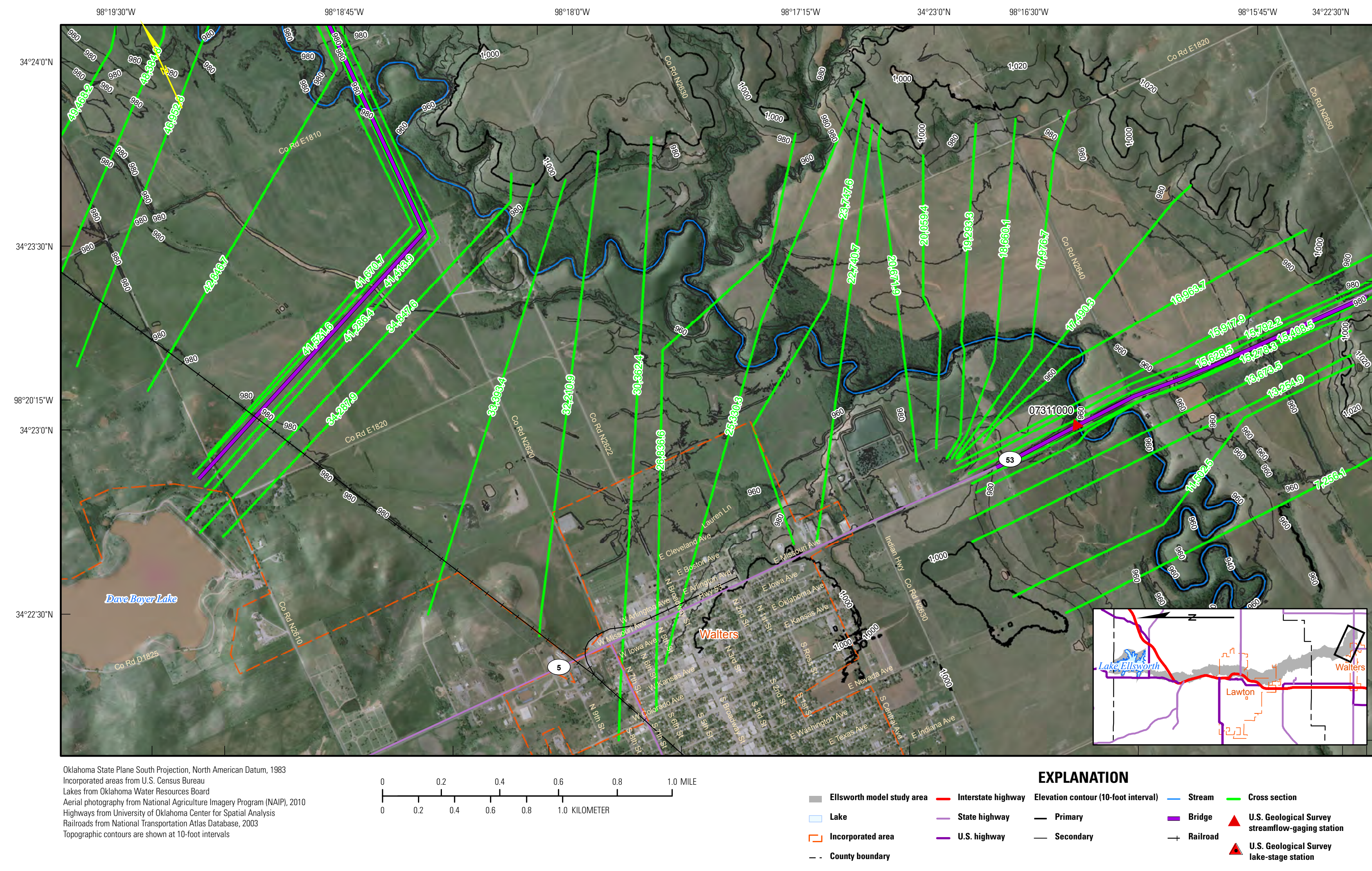

Figure 2-10. Cross-section locations for Lake Ellsworth, near Lawton, Oklahoma, for the Hydrologic Engineering Center's River Analysis System (HEC-RAS) model (Hydrologic Engineering Center, 2010a). 


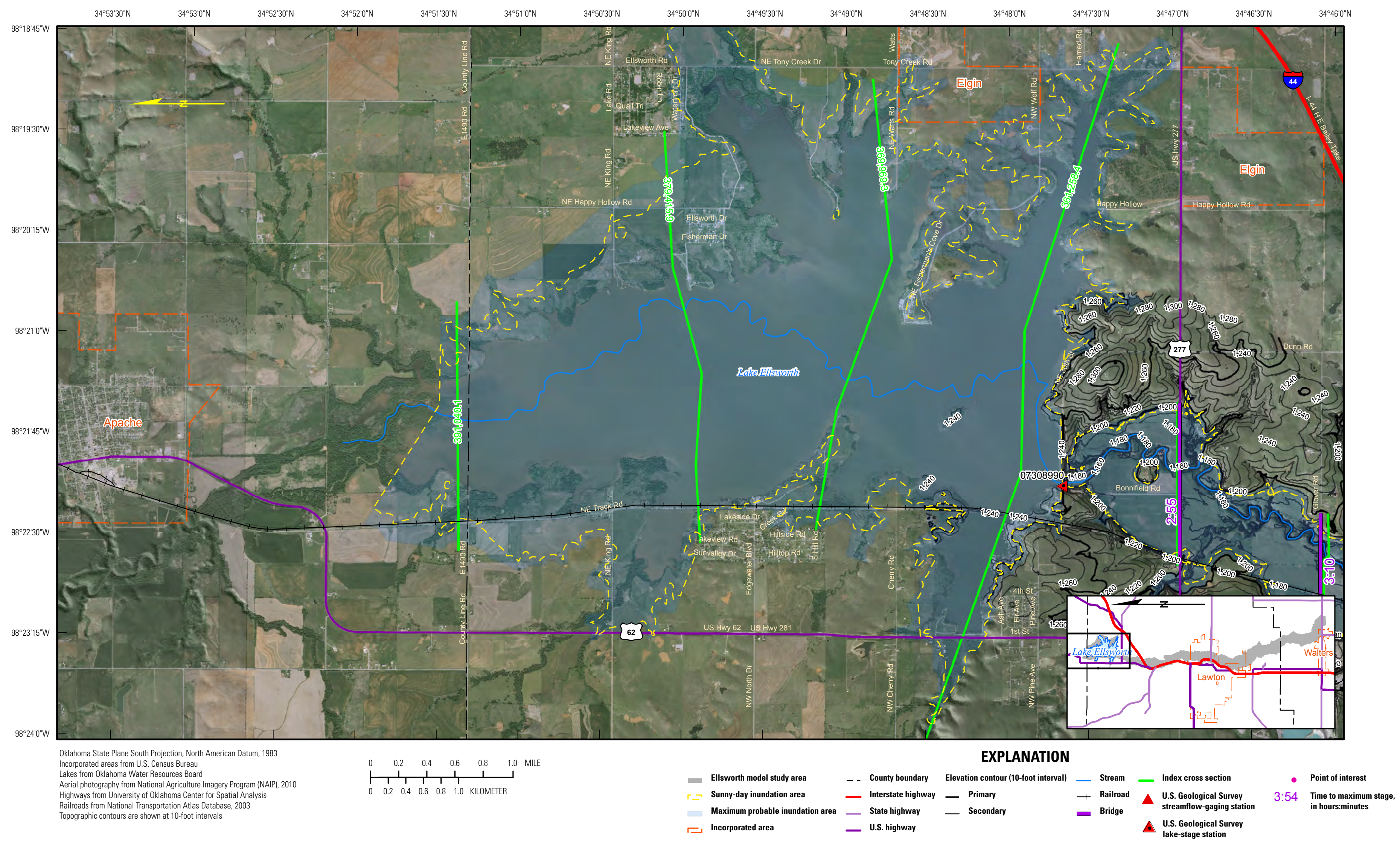

Figure 3-1. Inundated areas for dam-breach scenarios for Lake Ellsworth, near Lawton, Oklahoma, modeled by using the Hydrologic Engineering Center's River Analysis System (HEC-RAS) modeling software (Hydrologic Engineering Center, 2010a). 


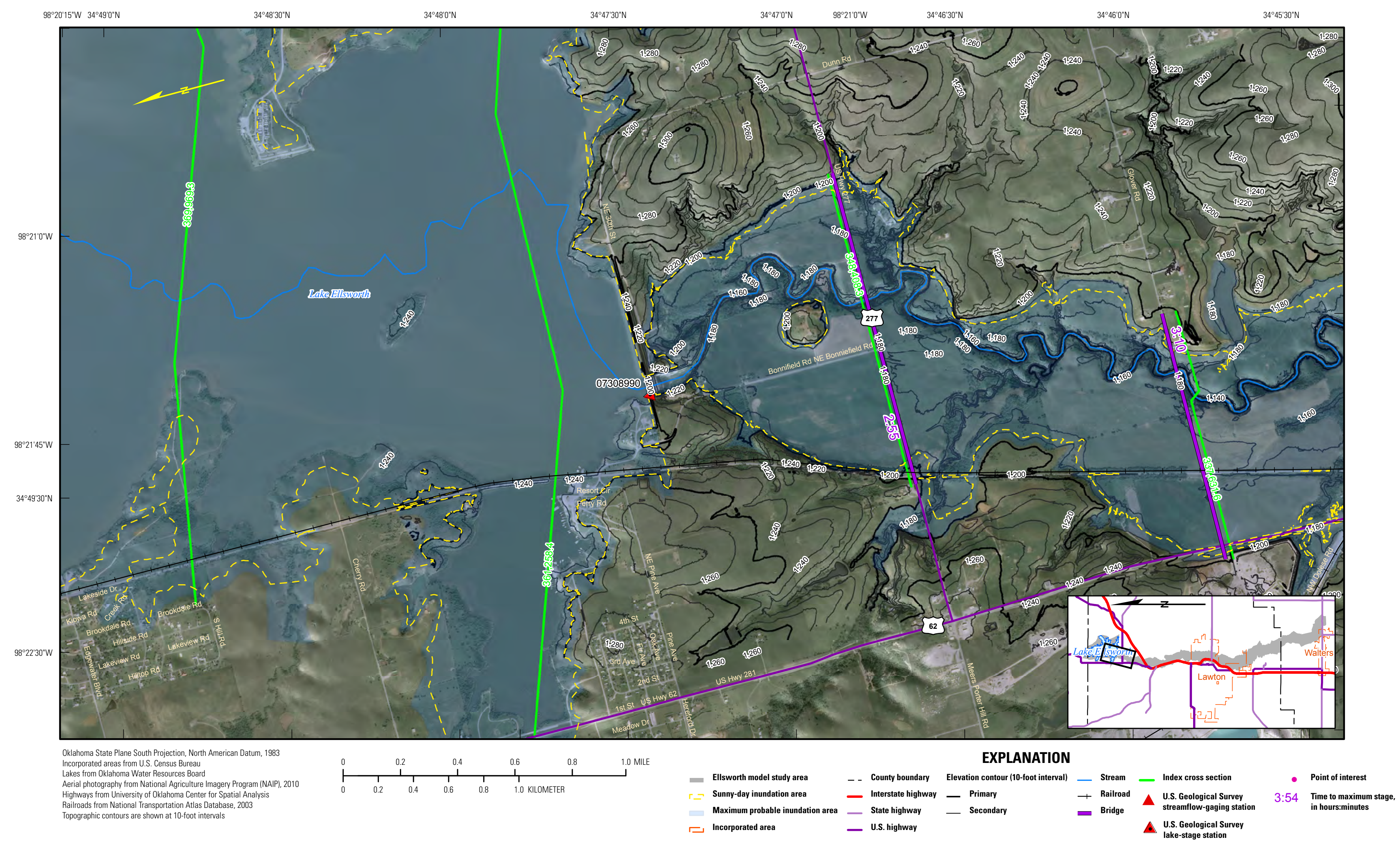

Figure 3-2. Inundated areas for dam-breach scenarios for Lake Ellsworth, near Lawton, Oklahoma, modeled by using the Hydrologic Engineering Center's River Analysis System (HEC-RAS) modeling software (Hydrologic Engineering Center, 2010a). 


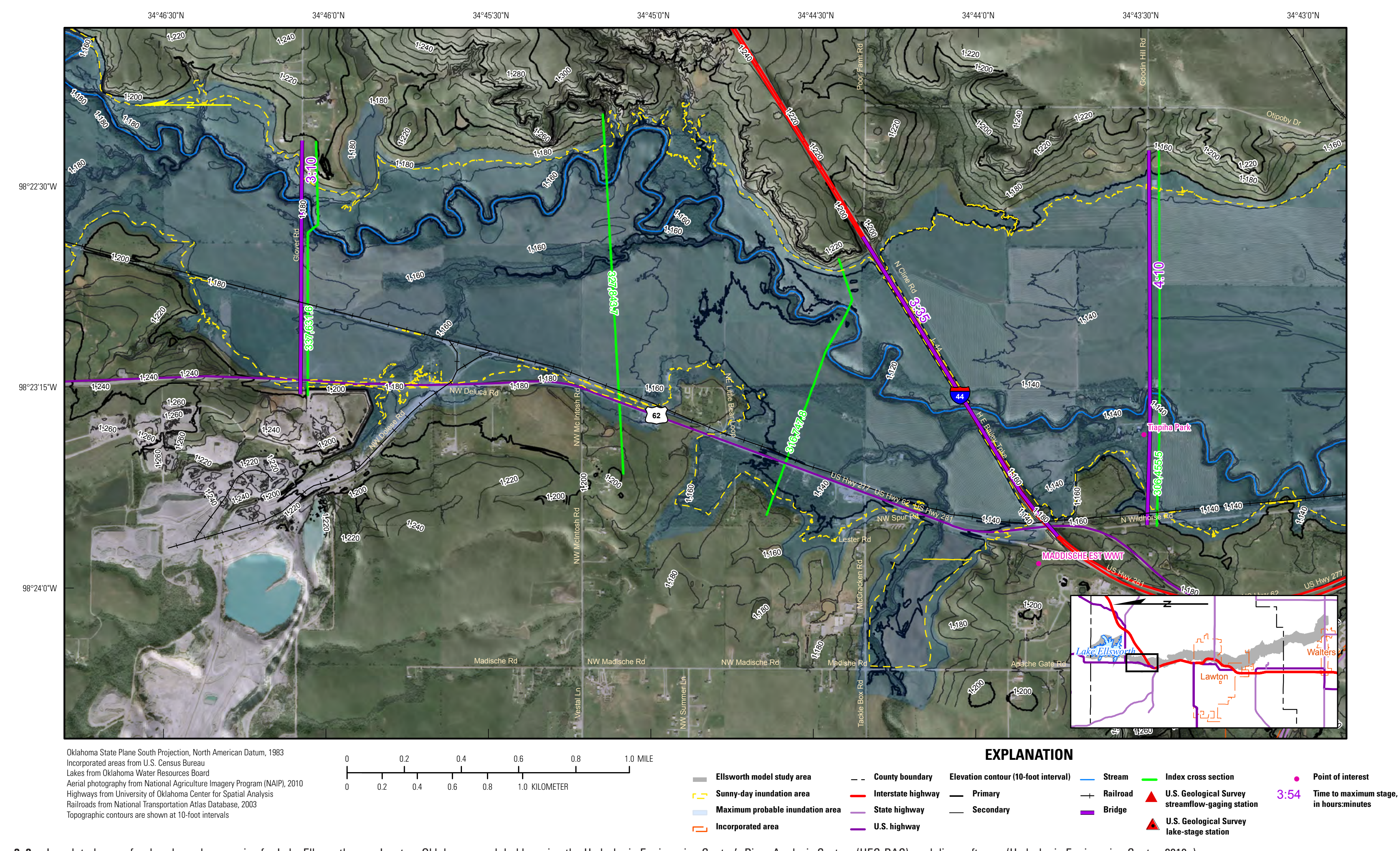

Figure 3-3. Inundated areas for dam-breach scenarios for Lake Ellsworth, near Lawton, Oklahoma, modeled by using the Hydrologic Engineering Center's River Analysis System (HEC-RAS) modeling software (Hydrologic Engineering Center, 2010a). 


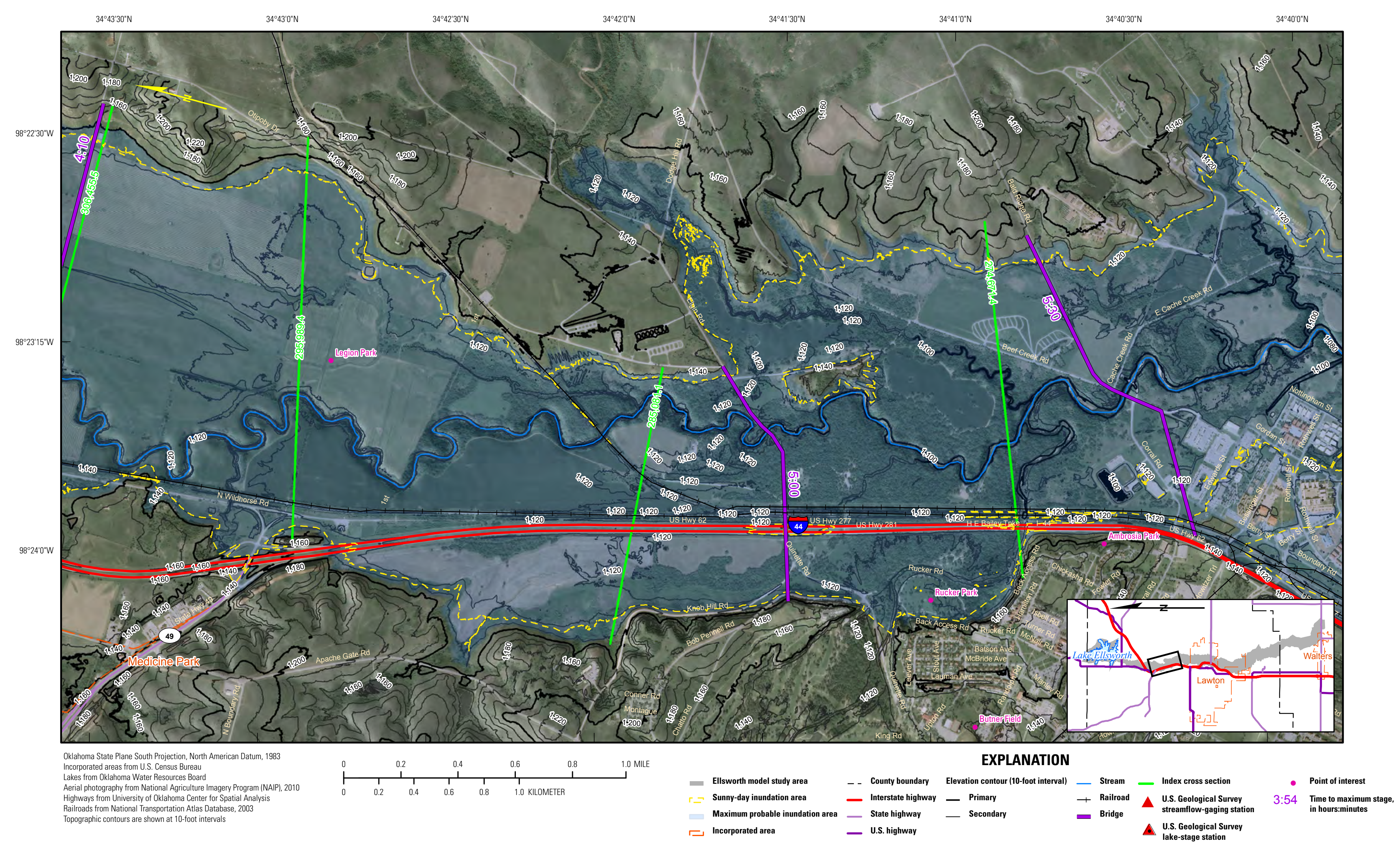

Figure 3-4. Inundated areas for dam-breach scenarios for Lake Ellsworth, near Lawton, Oklahoma, modeled by using the Hydrologic Engineering Center's River Analysis System (HEC-RAS) modeling software (Hydrologic Engineering Center, 2010a). 


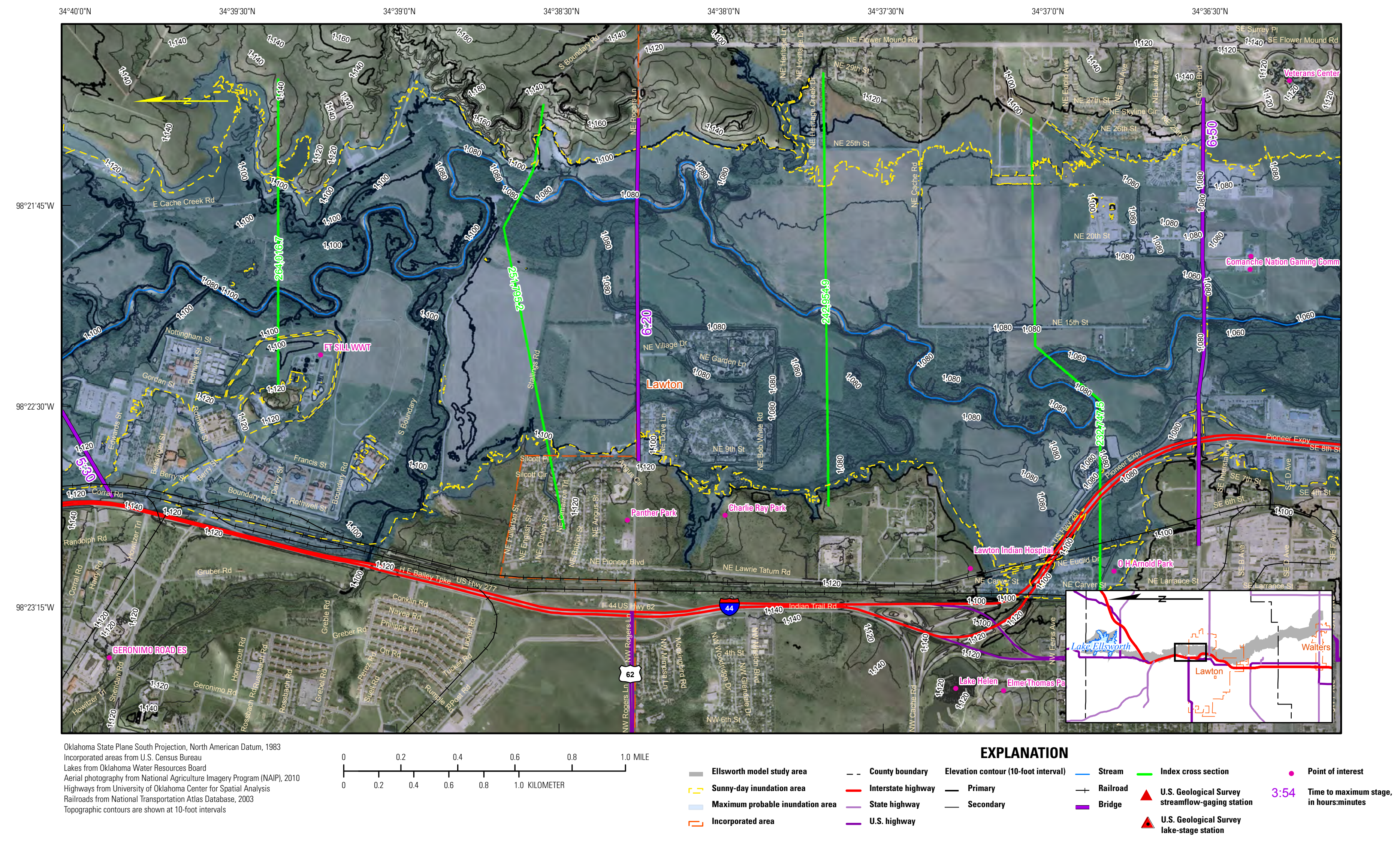

Figure 3-5. Inundated areas for dam-breach scenarios for Lake Ellsworth, near Lawton, Oklahoma, modeled by using the Hydrologic Engineering Center's River Analysis System (HEC-RAS) modeling software (Hydrologic Engineering Center, 2010a). 


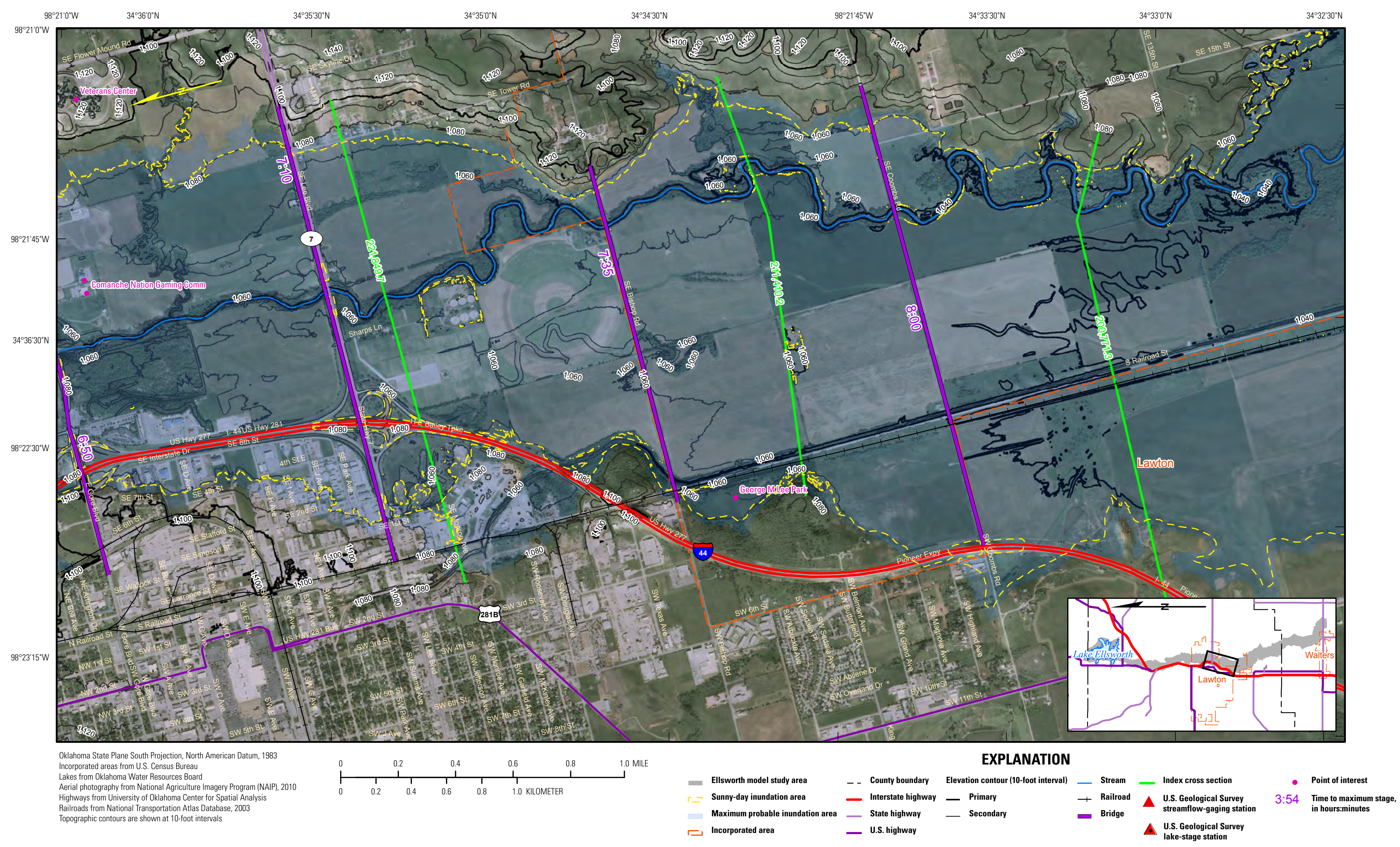

Figure 3-6. Inundated areas for dam-breach scenarios for Lake Ellsworth, near Lawton, Oklahoma, modeled by using the Hydrologic Engineering Center's River Analysis System (HEC-RAS) modeling software (Hydrologic Engineering Center, 2010a). 


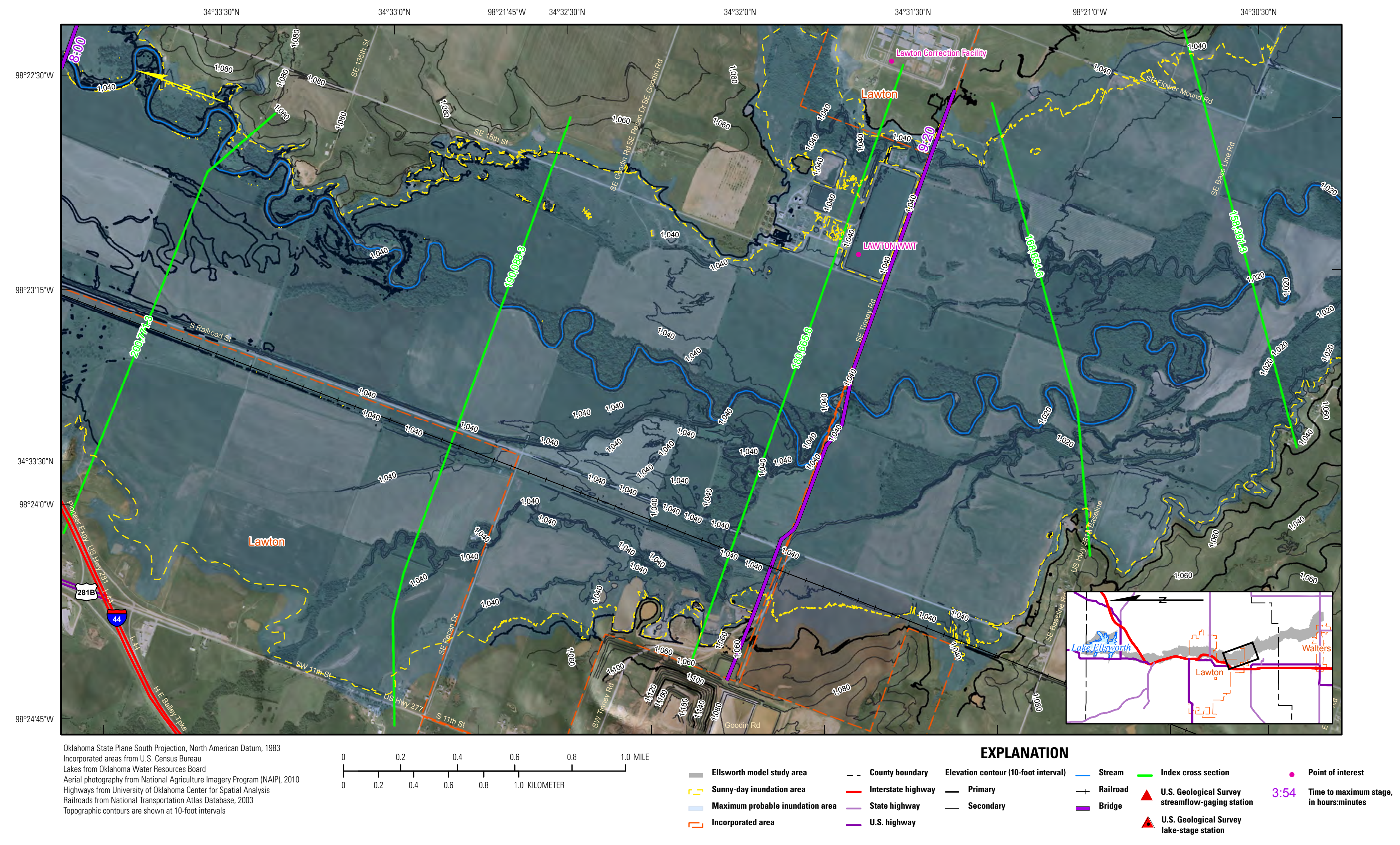

Figure 3-7. Inundated areas for dam-breach scenarios for Lake Ellsworth, near Lawton, Oklahoma, modeled by using the Hydrologic Engineering Center's River Analysis System (HEC-RAS) modeling software (Hydrologic Engineering Center, 2010a). 


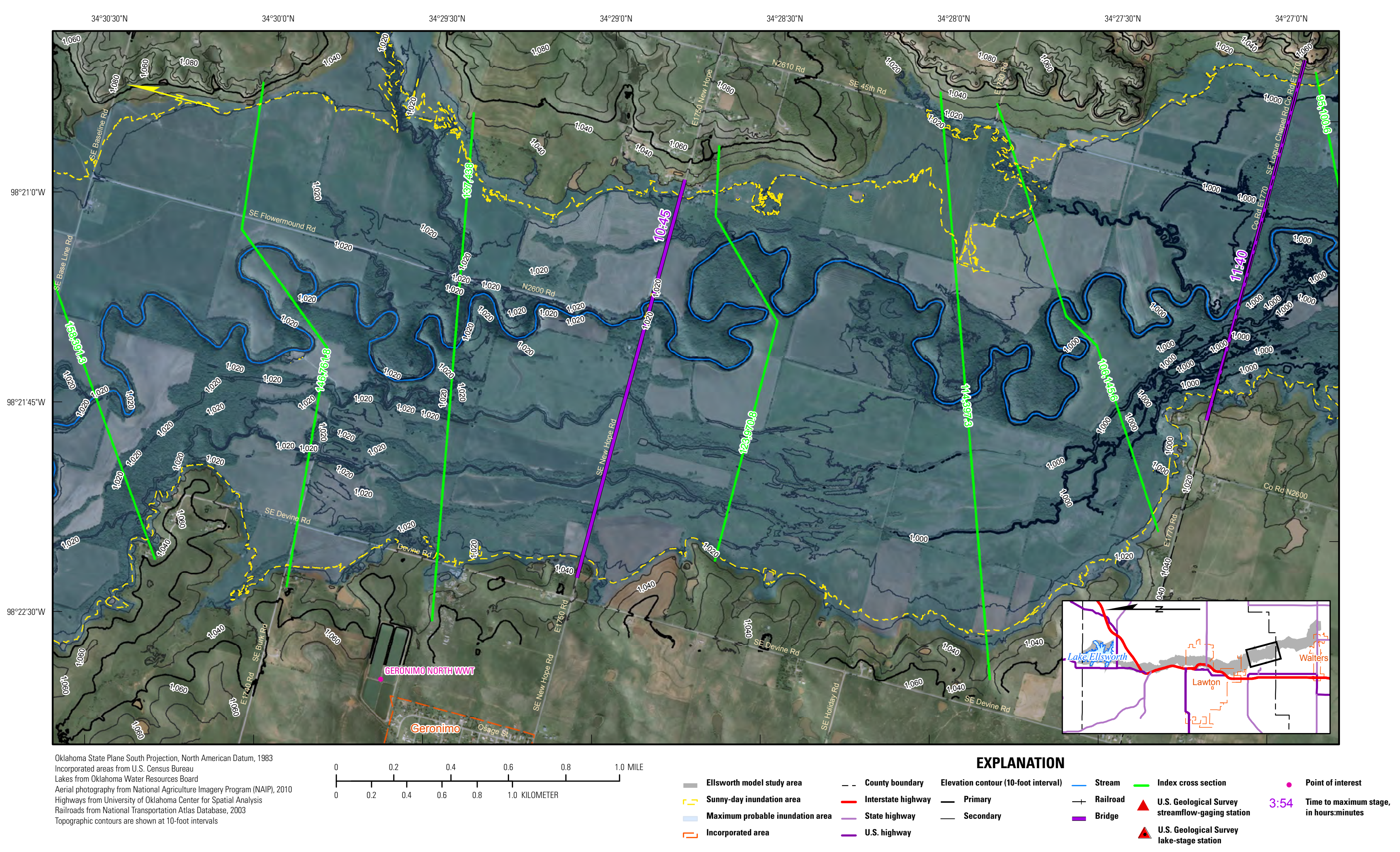




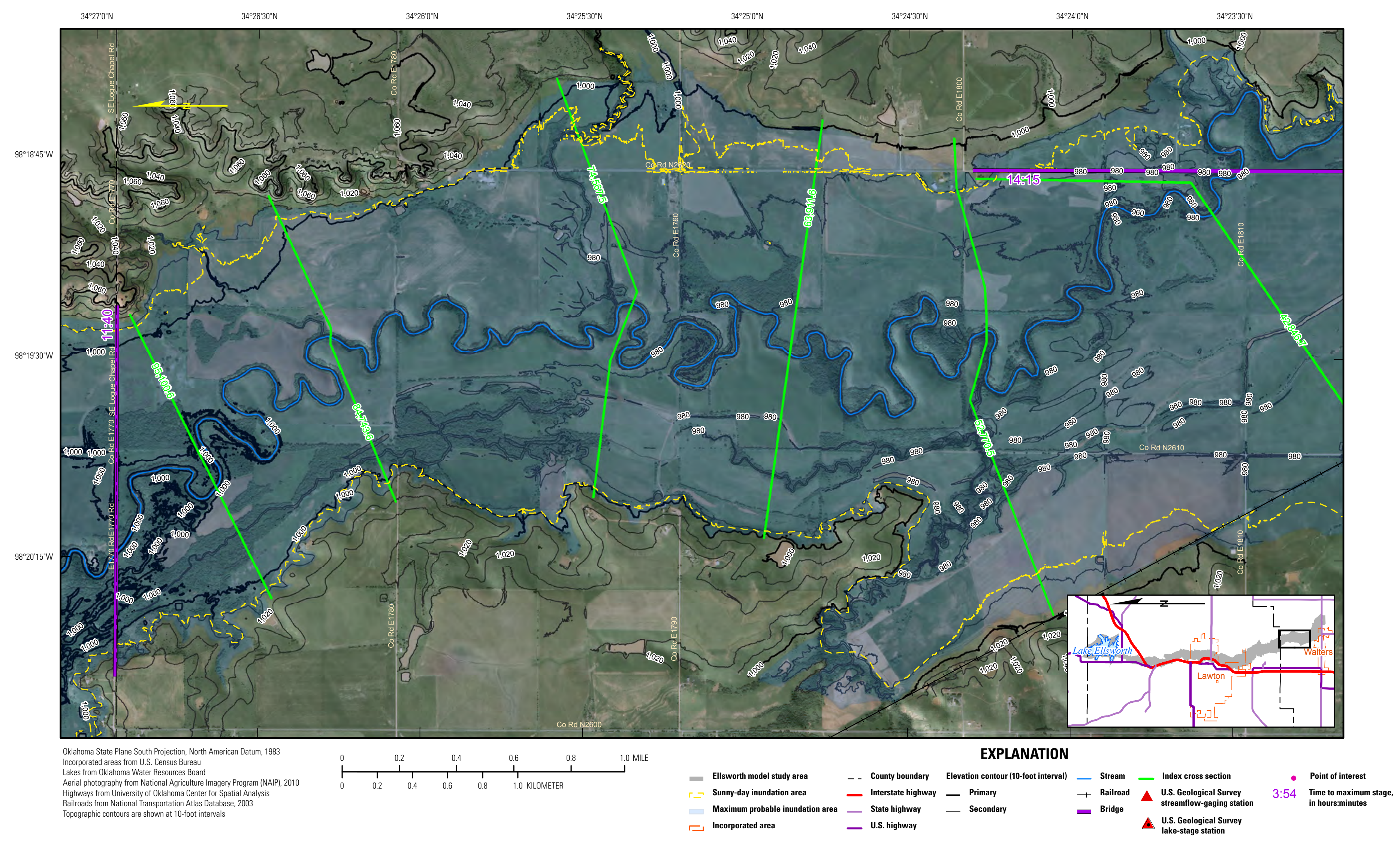

Figure 3-9. Inundated areas for dam-breach scenarios for Lake Ellsworth, near Lawton, Oklahoma, modeled by using the Hydrologic Engineering Center's River Analysis System (HEC-RAS) modeling software (Hydrologic Engineering Center, 2010a). 

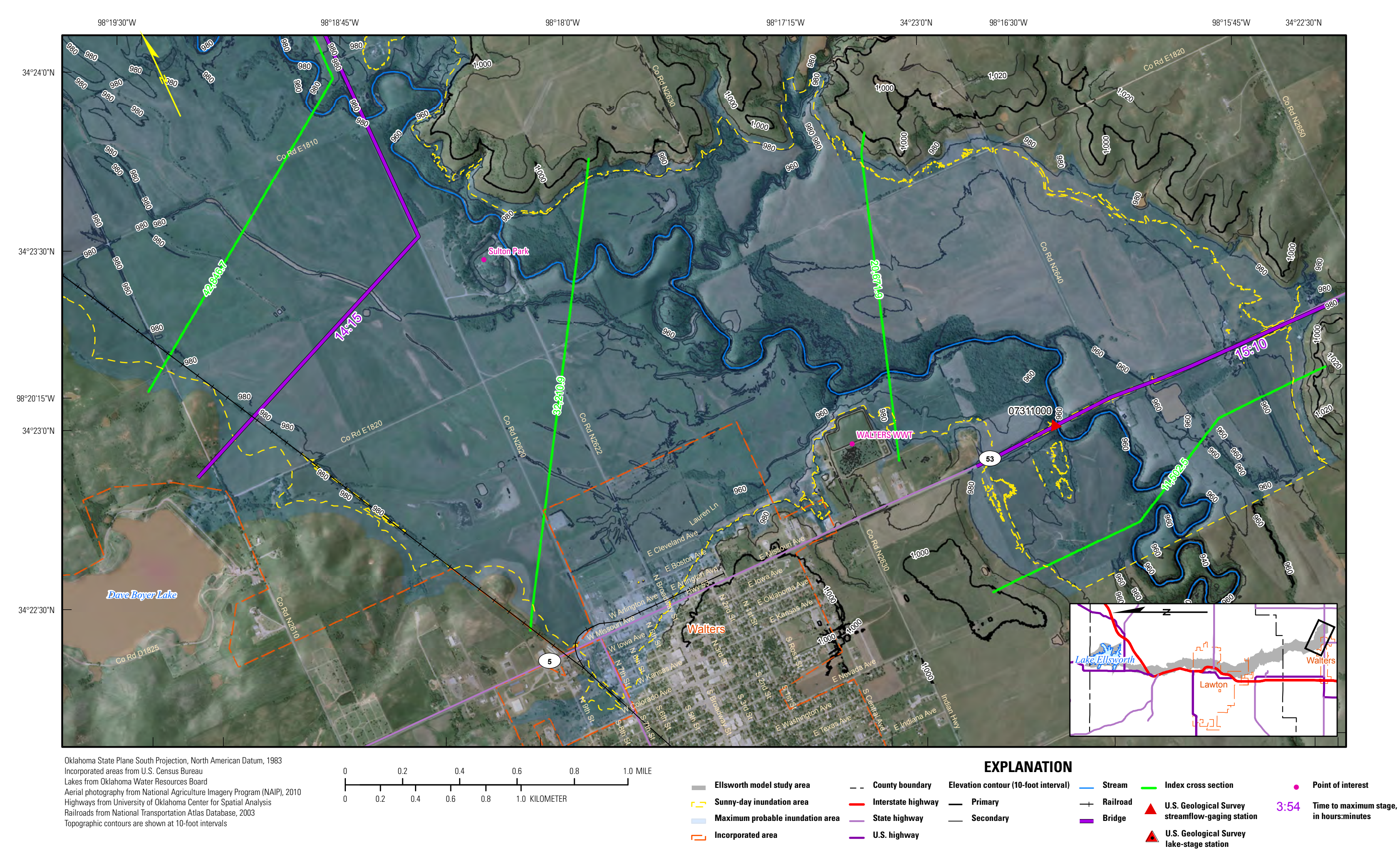

Figure 3-10. Inundated areas for dam-breach scenarios for Lake Ellsworth, near Lawton, Oklahoma, modeled by using the Hydrologic Engineering Center's River Analysis System (HEC-RAS) modeling software (Hydrologic Engineering Center, 2010a). 


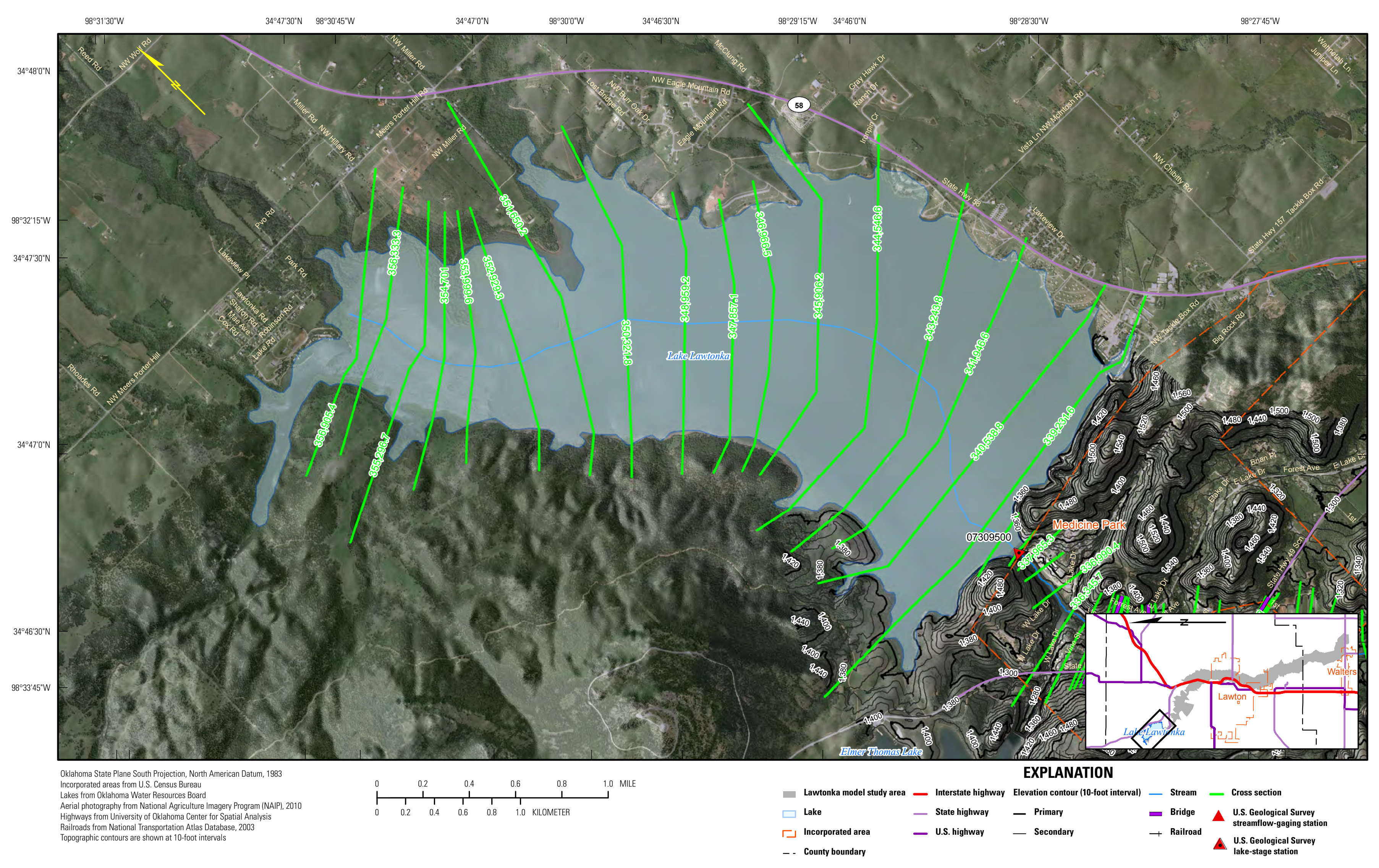

Figure 4-1. Cross-section locations for Lake Lawtonka, near Lawton, Oklahoma, for the Hydrologic Engineering Center's River Analysis System (HEC-RAS) model (Hydrologic Engineering Center, 2010a). 
34 Dam-Breach Analysis and Flood-Inundation Mapping for Lakes Ellsworth and Lawtonka near Lawton, Oklahoma

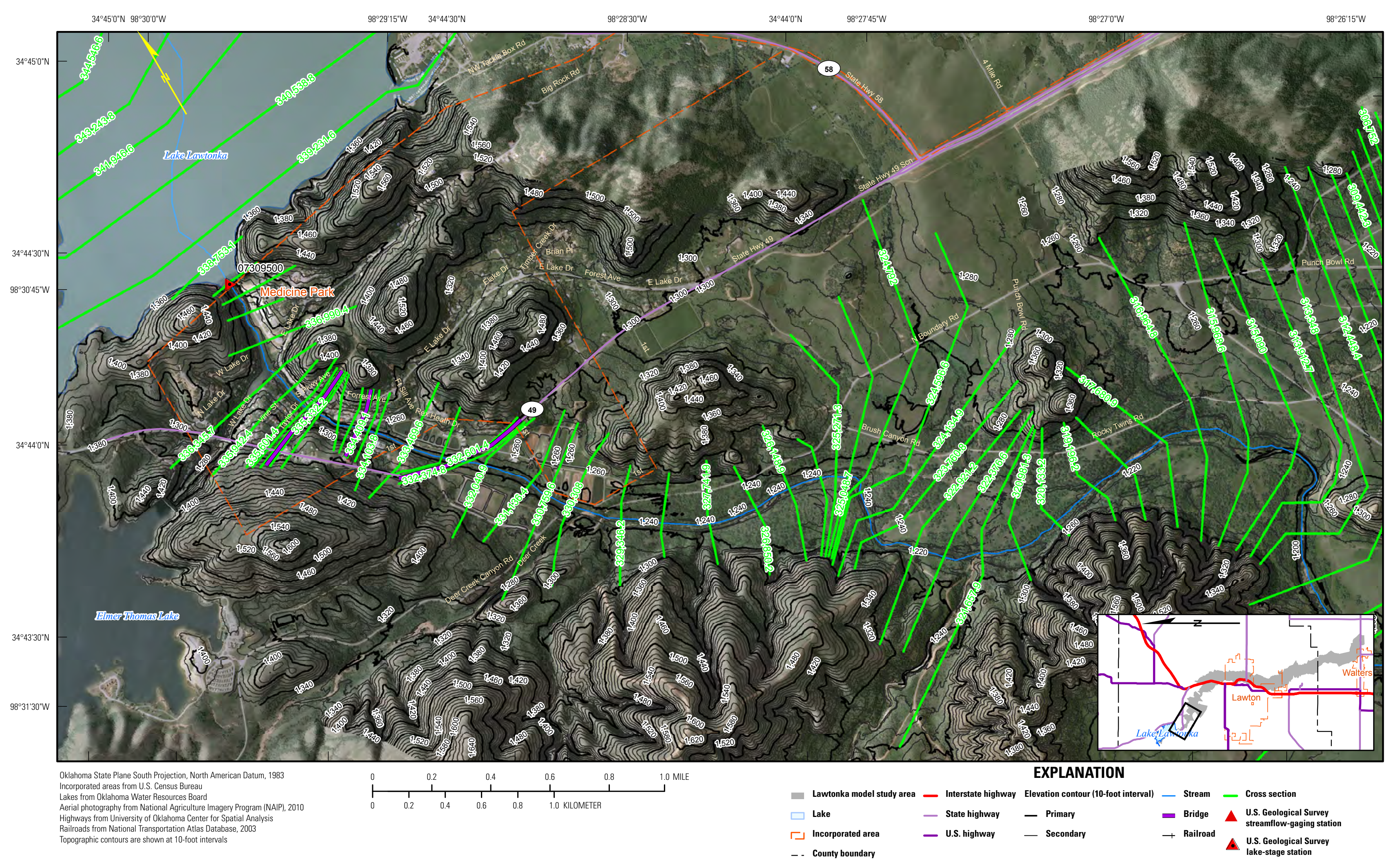

Figure 4-2. Cross-section locations for Lake Lawtonka, near Lawton, Oklahoma, for the Hydrologic Engineering Center's River Analysis System (HEC-RAS) model (Hydrologic Engineering Center, 2010a). 


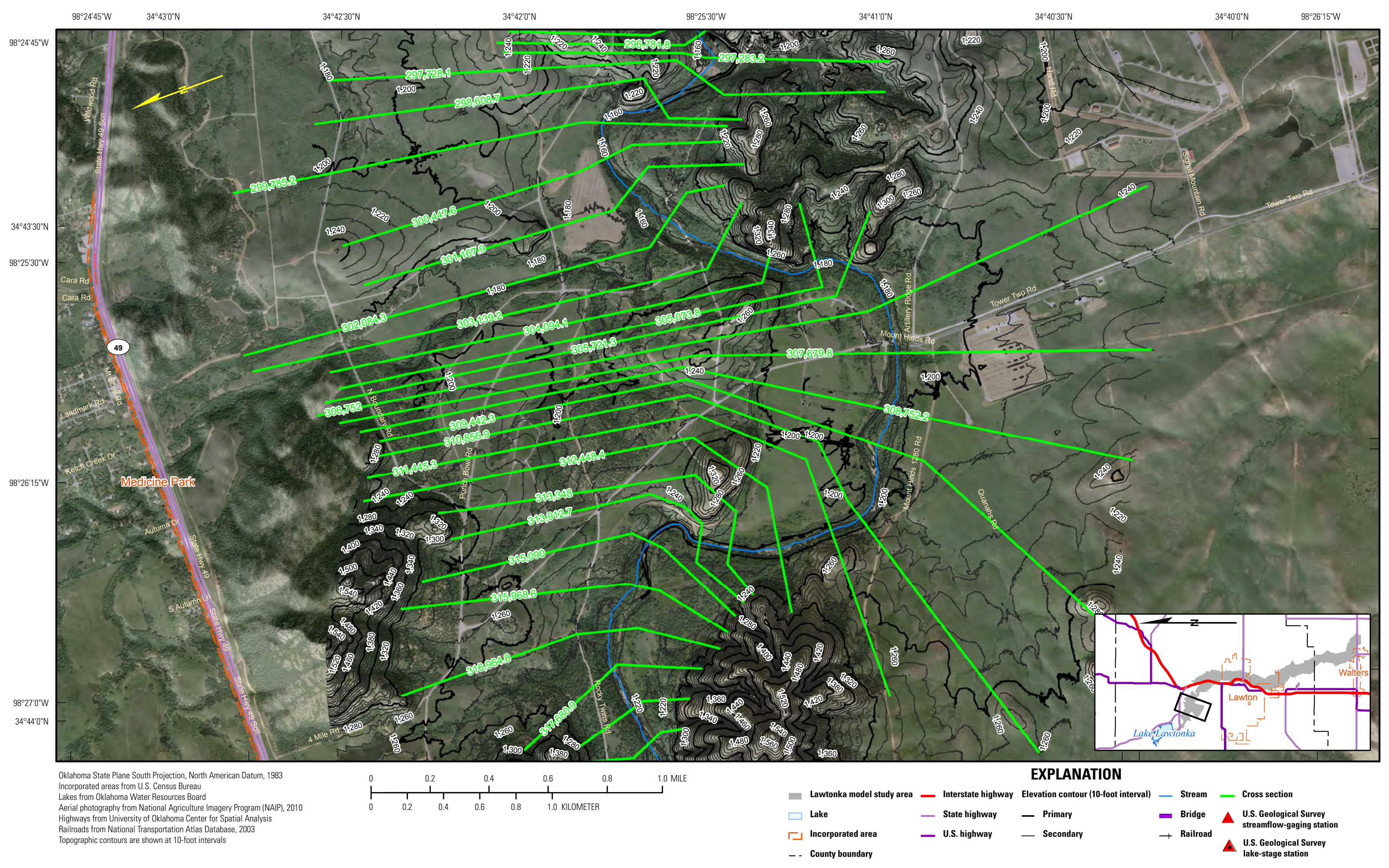




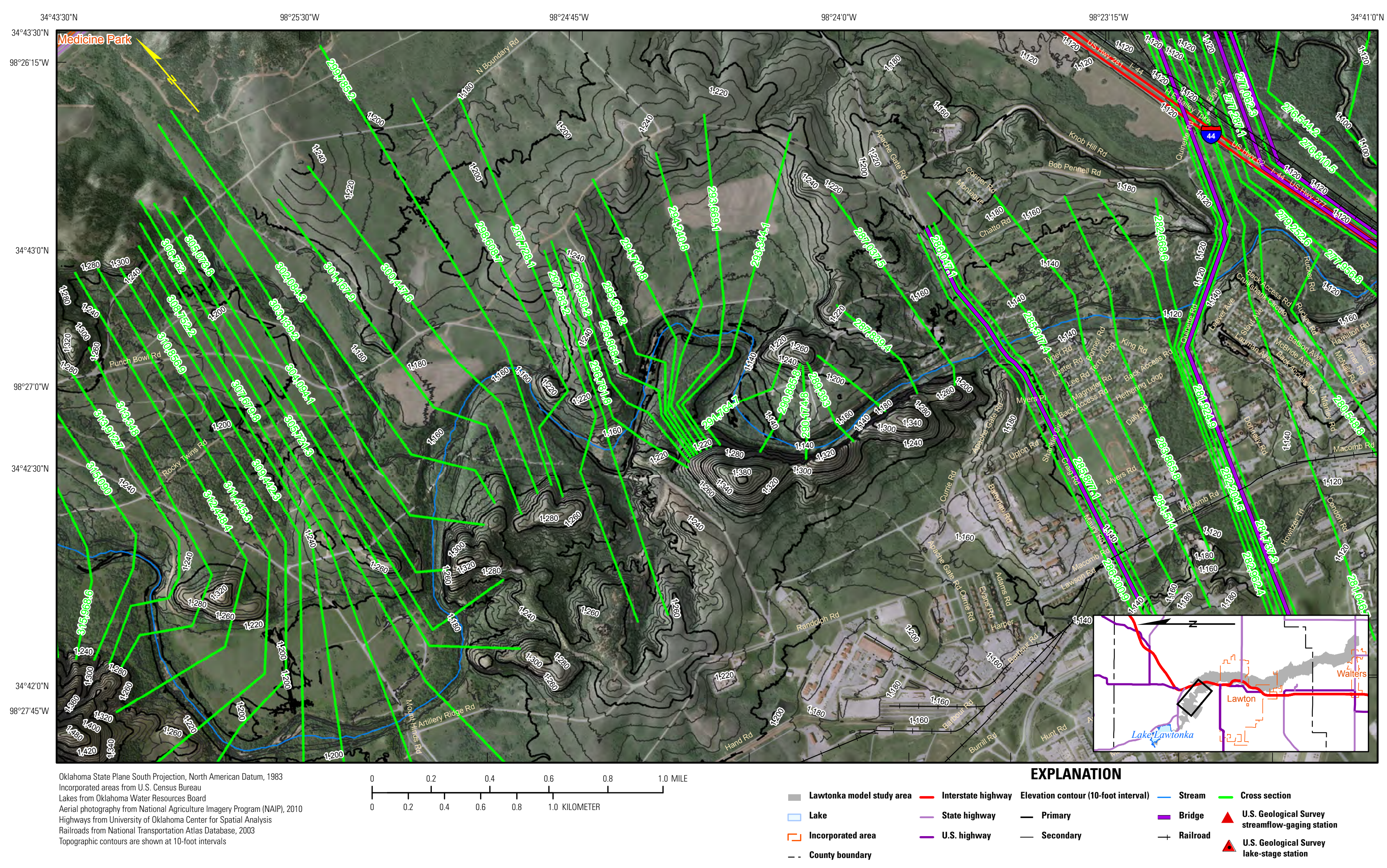

Figure 4-4. Cross-section locations for Lake Lawtonka, near Lawton, 0klahoma, for the Hydrologic Engineering Center's River Analysis System (HEC-RAS) model (Hydrologic Engineering Center, 2010a). 


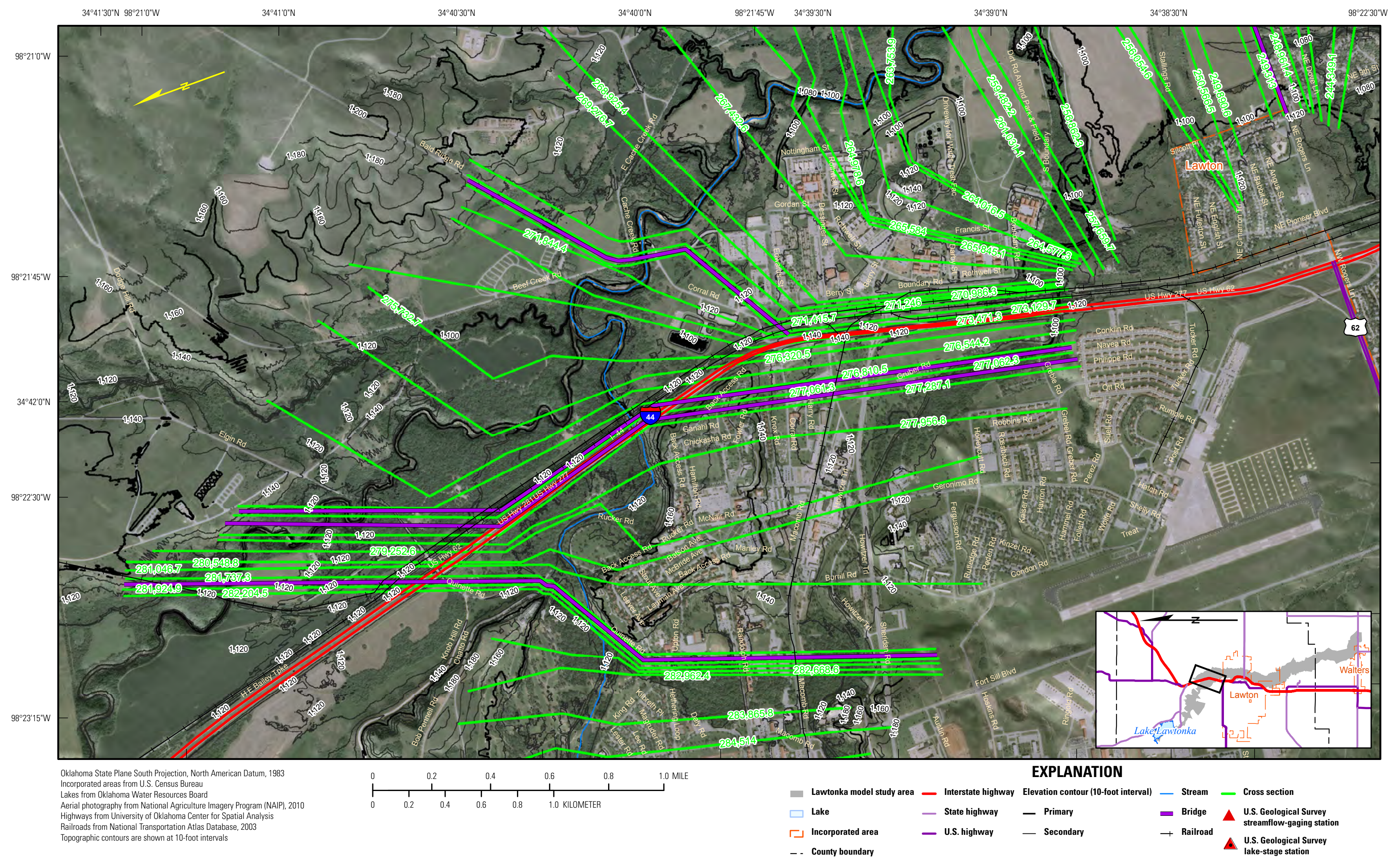

Figure 4-5. Cross-section locations for Lake Lawtonka, near Lawton, 0klahoma, for the Hydrologic Engineering Center's River Analysis System (HEC-RAS) model (Hydrologic Engineering Center, 2010a). 


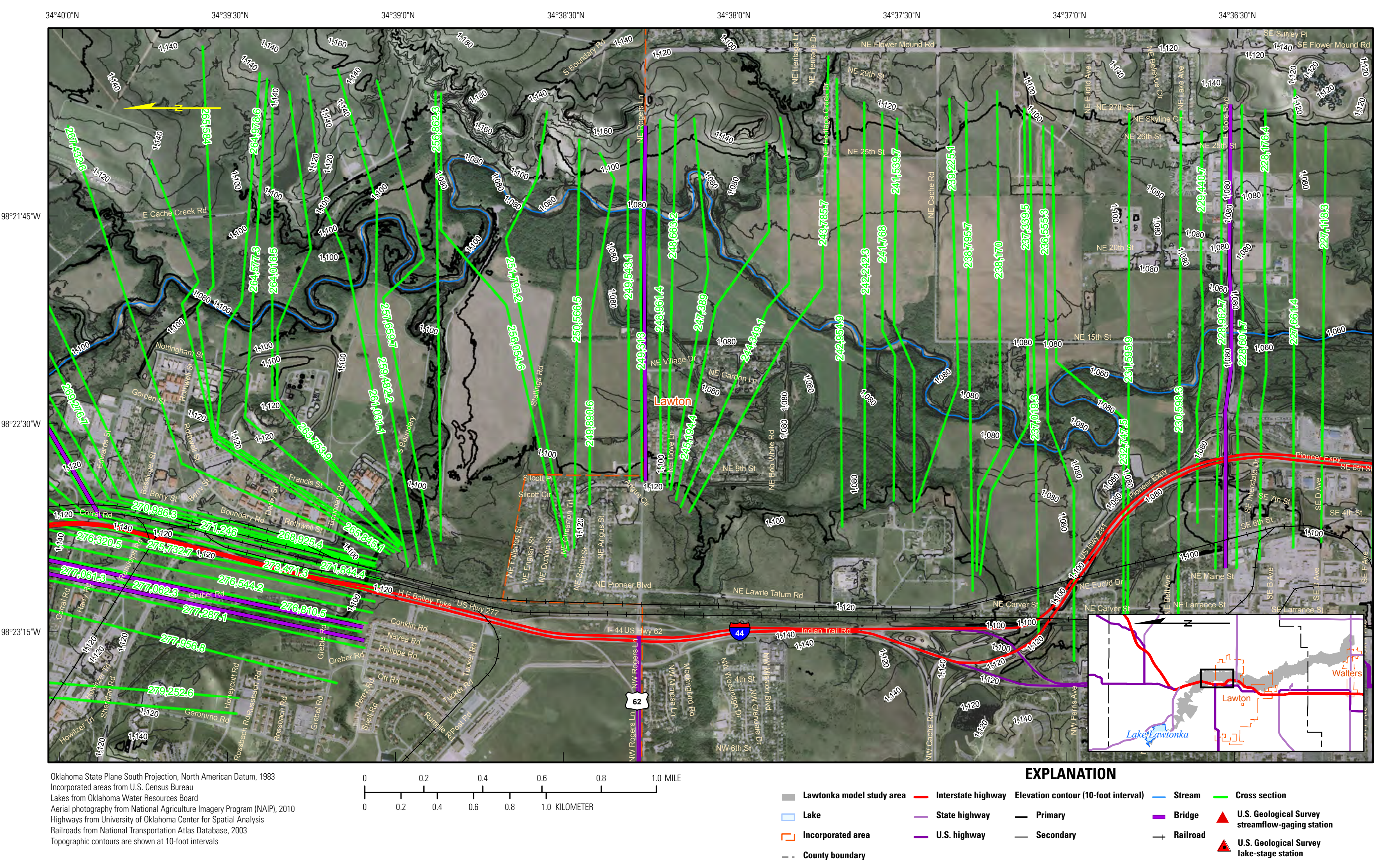

Figure 4-6. Cross-section locations for Lake Lawtonka, near Lawton, Oklahoma, for the Hydrologic Engineering Center's River Analysis System (HEC-RAS) model (Hydrologic Engineering Center, 2010a). 


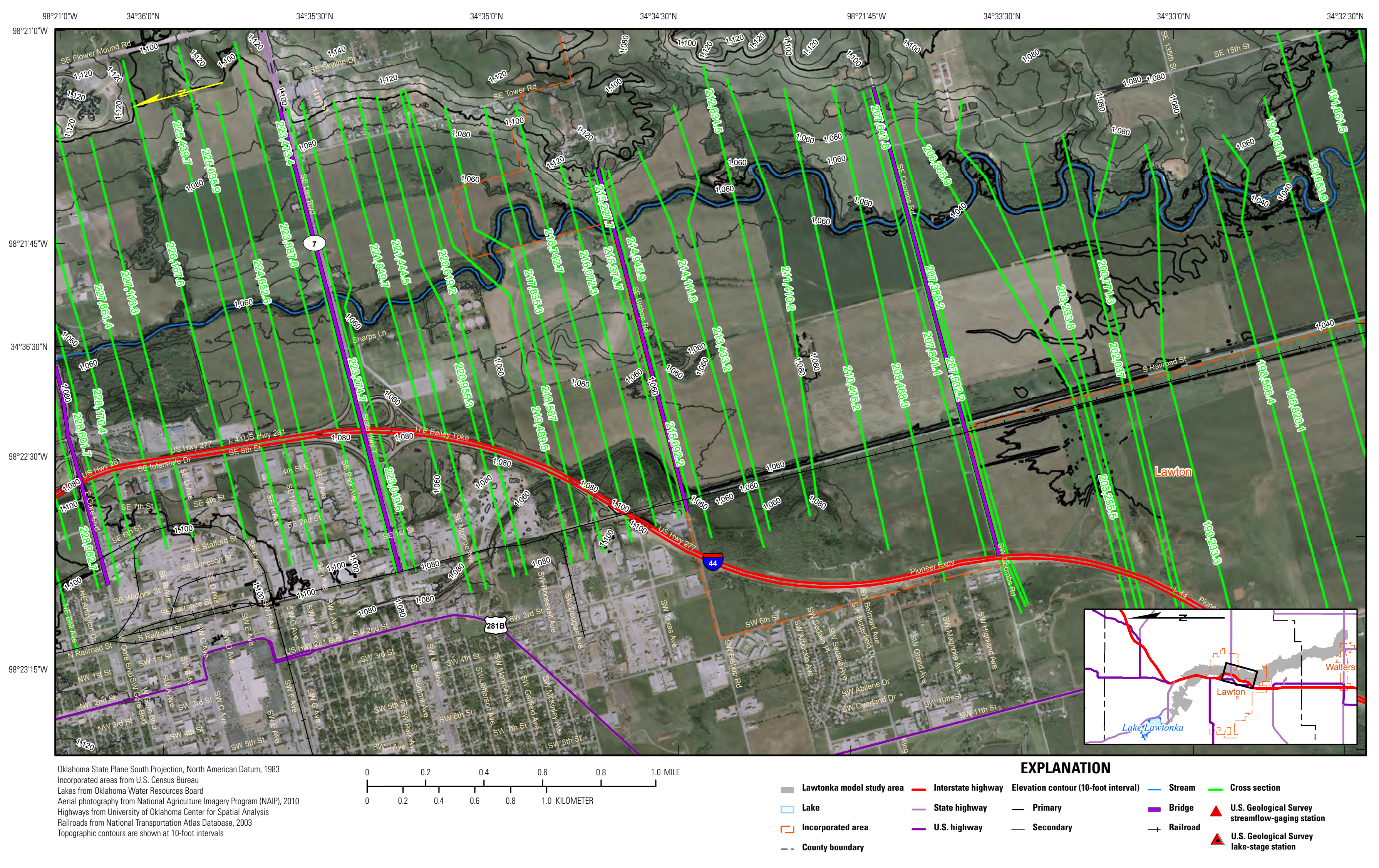

Figure 4-7. Cross-section locations for Lake Lawtonka, near Lawton, 0klahoma, for the Hydrologic Engineering Center's River Analysis System (HEC-RAS) model (Hydrologic Engineering Center, 2010a). 


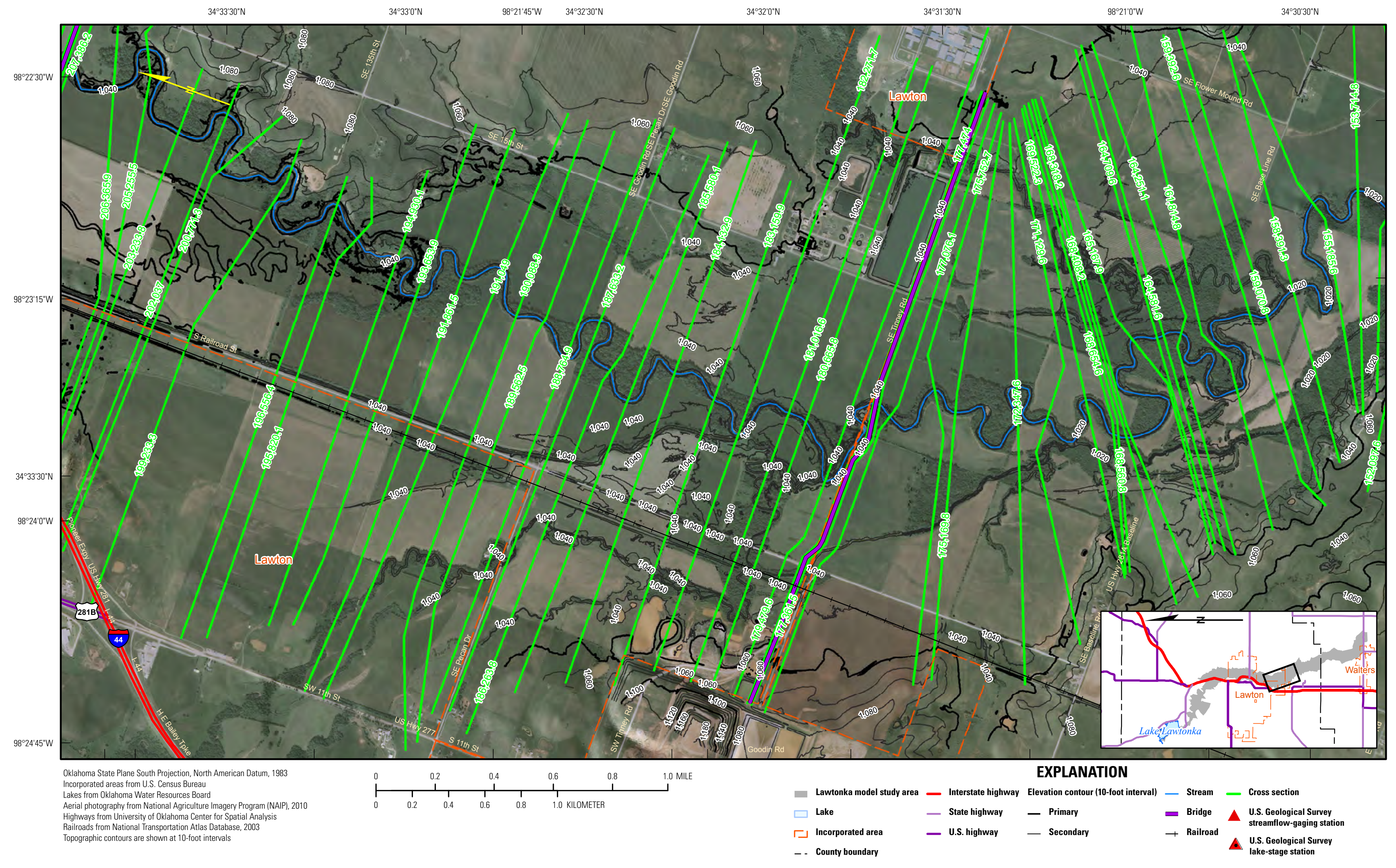

Figure 4-8. Cross-section locations for Lake Lawtonka, near Lawton, Oklahoma, for the Hydrologic Engineering Center's River Analysis System (HEC-RAS) model (Hydrologic Engineering Center, 2010a). 


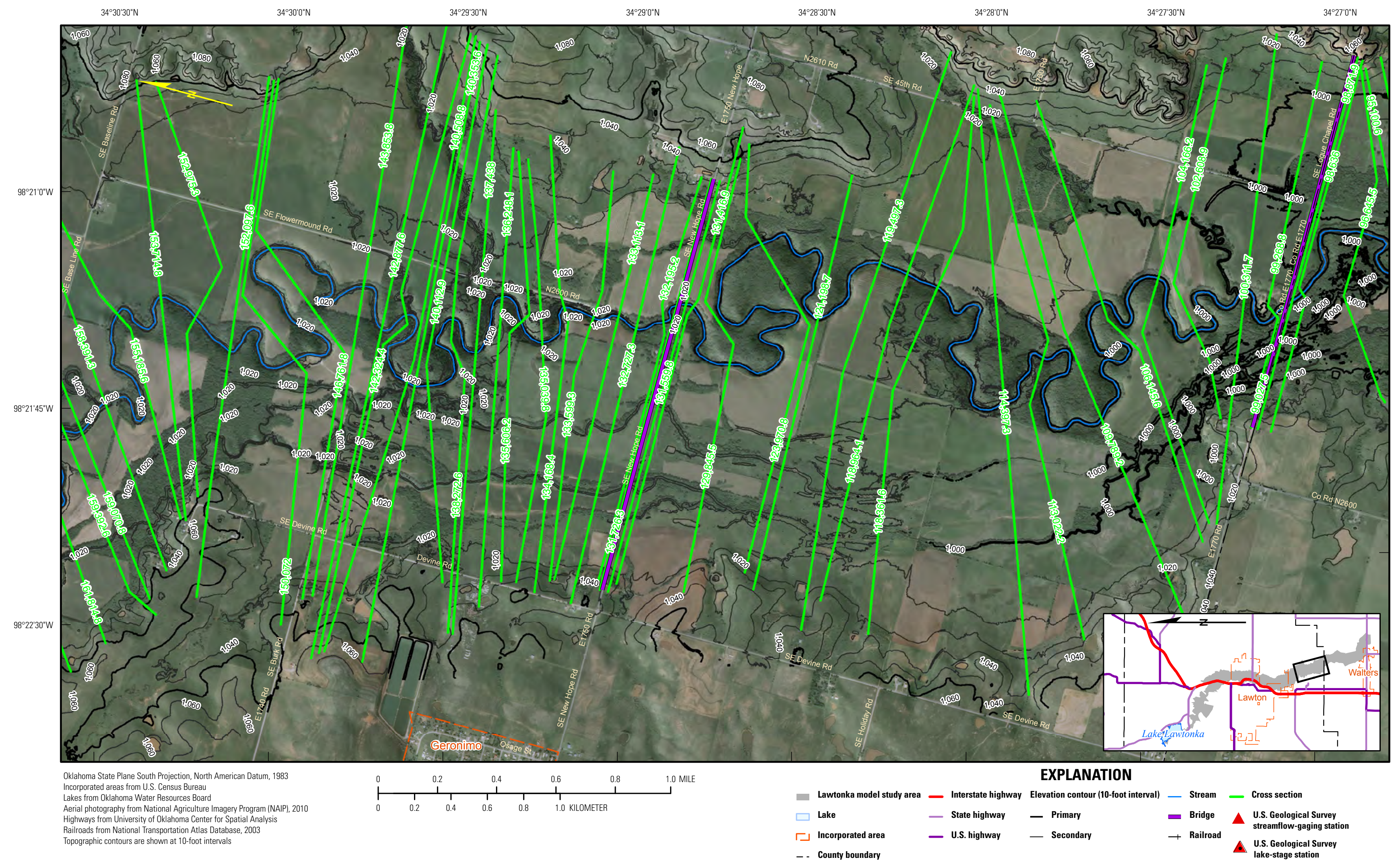

Figure 4-9. Cross-section locations for Lake Lawtonka, near Lawton, 0klahoma, for the Hydrologic Engineering Center's River Analysis System (HEC-RAS) model (Hydrologic Engineering Center, 2010a). 


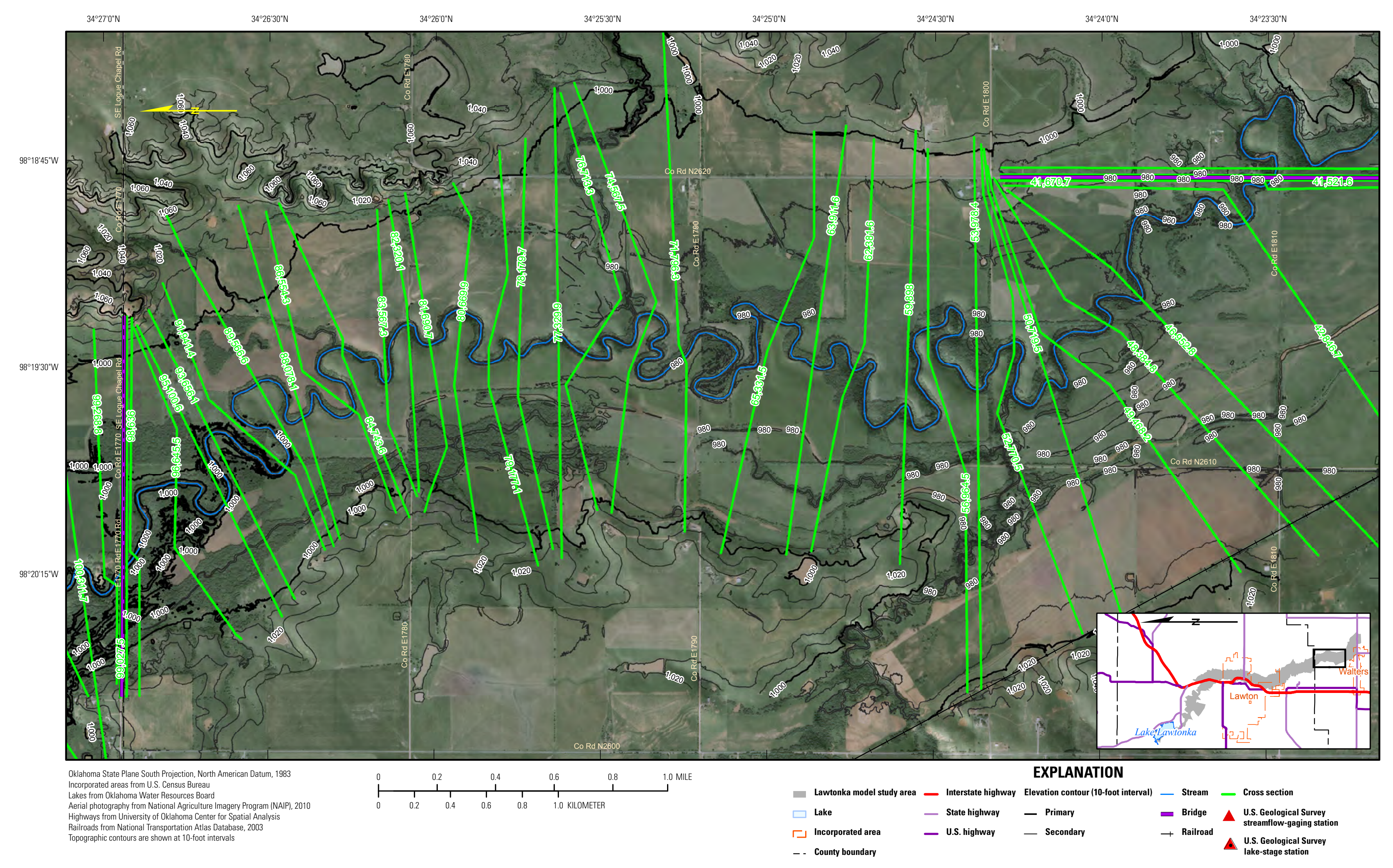

Figure 4-10. Cross-section locations for Lake Lawtonka, near Lawton, Oklahoma, for the Hydrologic Engineering Center's River Analysis System (HEC-RAS) model (Hydrologic Engineering Center, 2010a). 

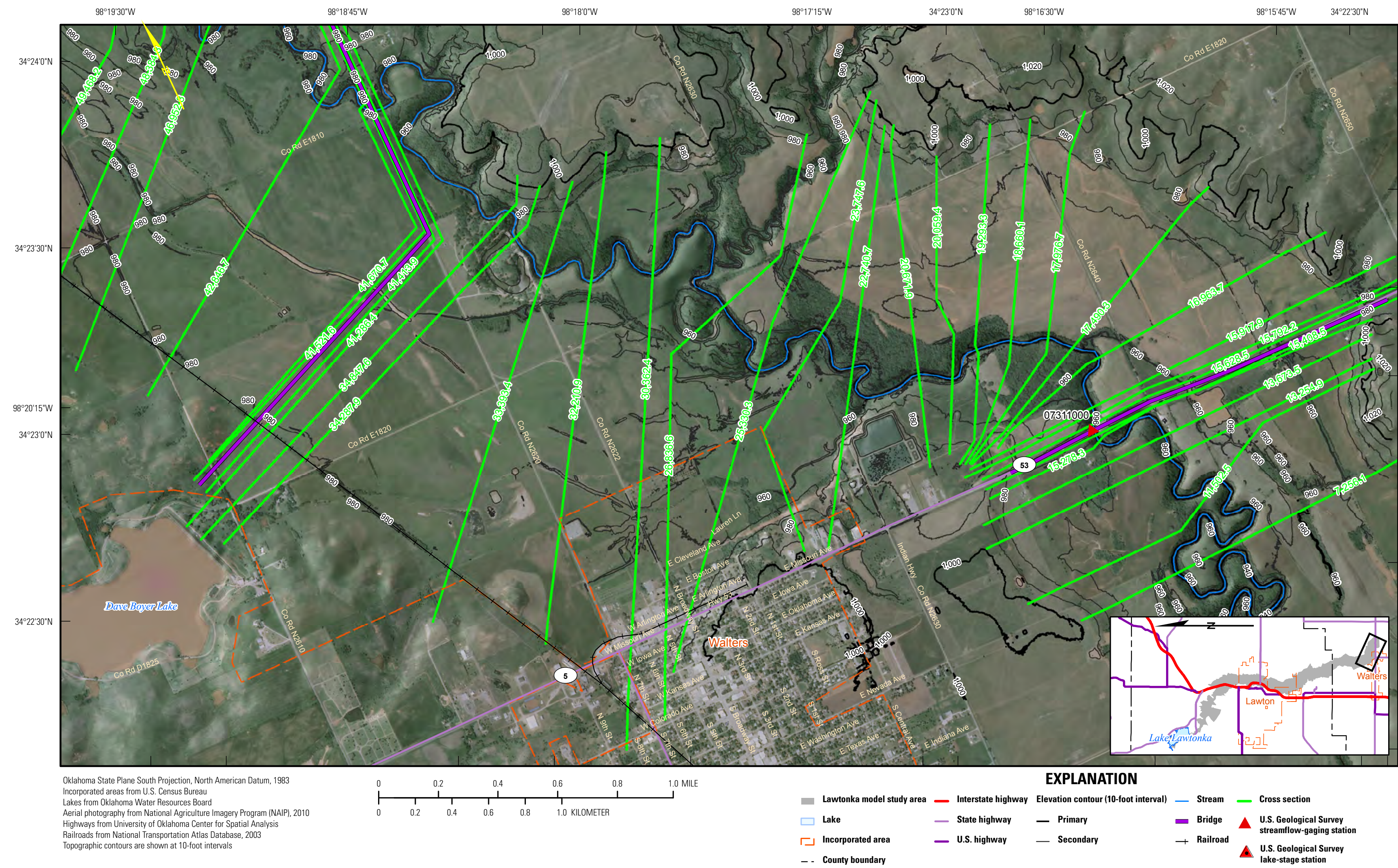

EXPLANATION

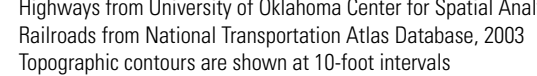

Figure 4-11. Cross-section locations for Lake Lawtonka, near Lawton, Oklahoma, for the Hydrologic Engineering Center's River Analysis System (HEC-RAS) model (Hydrologic Engineering Center, 2010a). 



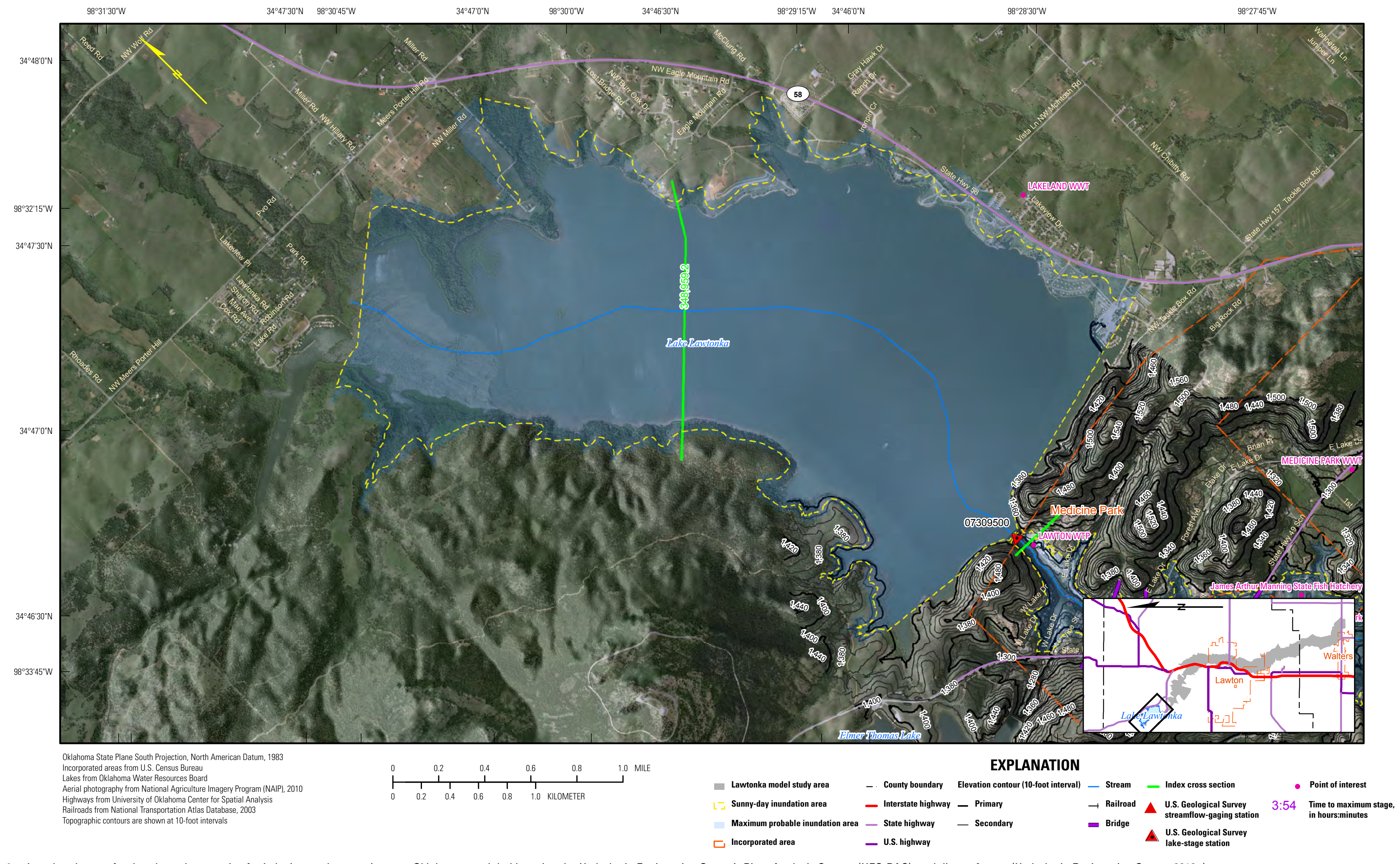

Figure 5-1. Inundated areas for dam-breach scenarios for Lake Lawtonka, near Lawton, 0klahoma, modeled by using the Hydrologic Engineering Center's River Analysis System (HEC-RAS) modeling software (Hydrologic Engineering Center, 2010a). 
46 Dam-Breach Analysis and Flood-Inundation Mapping for Lakes Ellsworth and Lawtonka near Lawton, Oklahoma

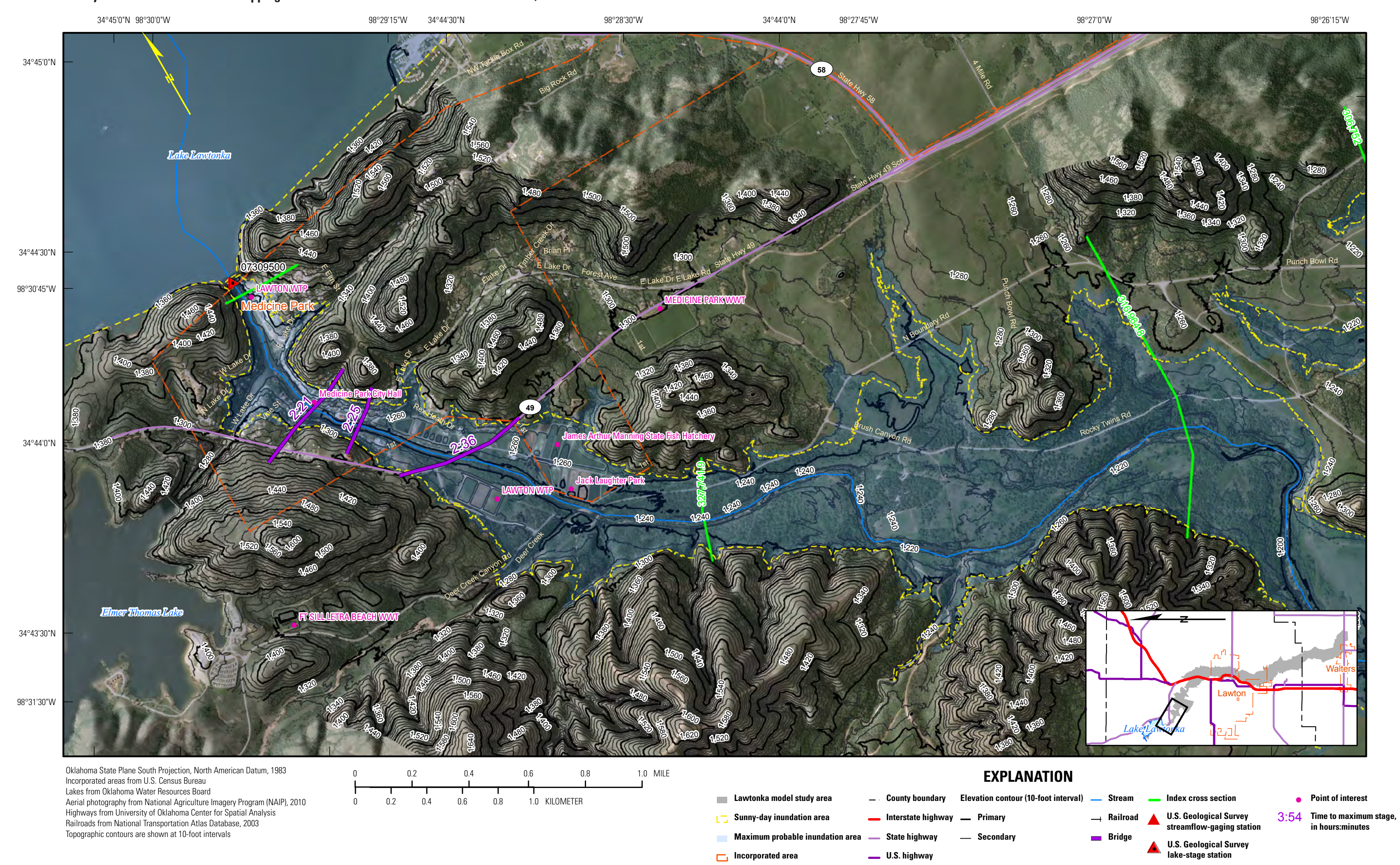

Figure 5-2. Inundated areas for dam-breach scenarios for Lake Lawtonka, near Lawton, 0klahoma, modeled by using the Hydrologic Engineering Center's River Analysis System (HEC-RAS) modeling software (Hydrologic Engineering Center, 2010a). 


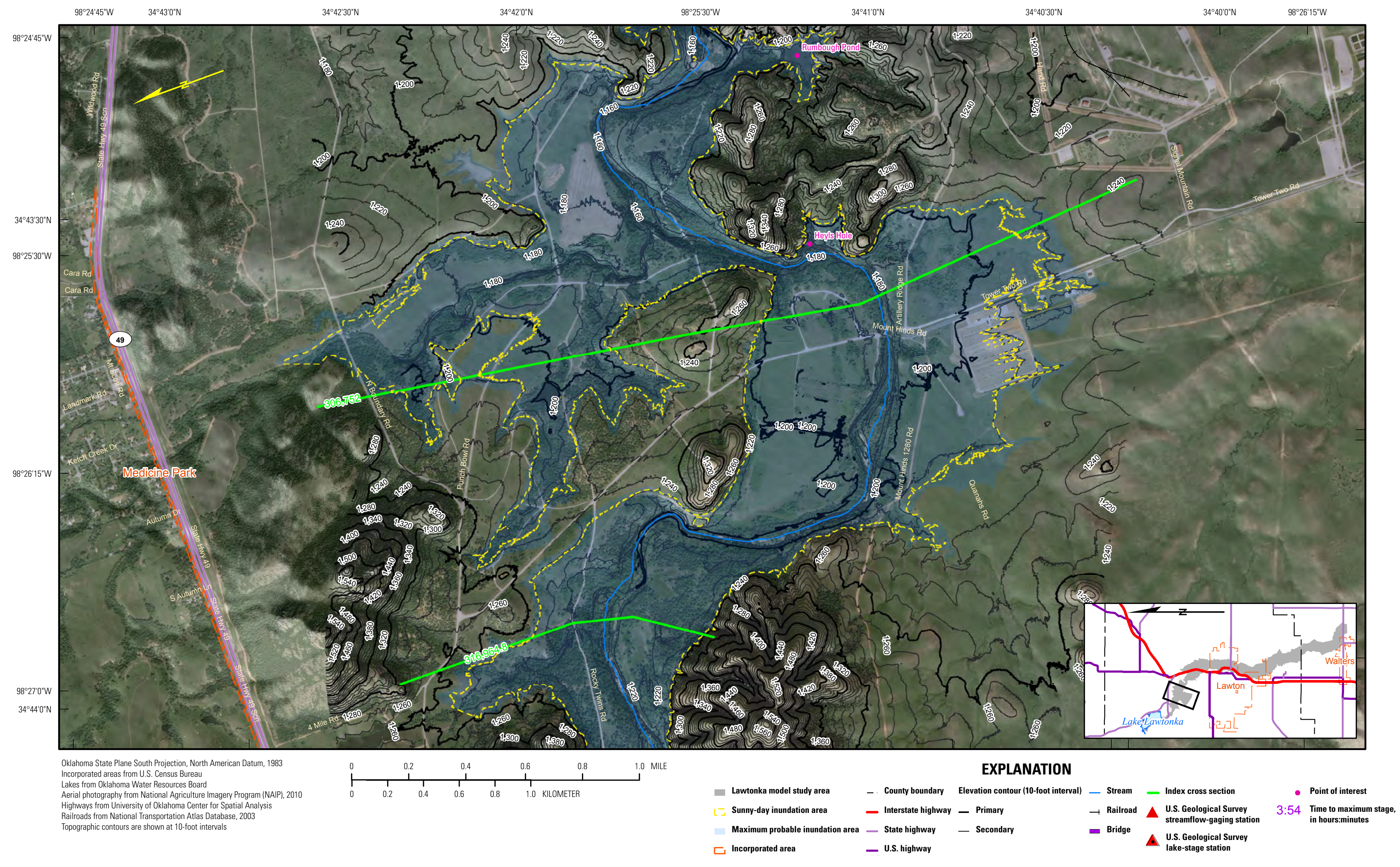

Figure 5-3. Inundated areas for dam-breach scenarios for Lake Lawtonka, near Lawton, 0klahoma, modeled by using the Hydrologic Engineering Center's River Analysis System (HEC-RAS) modeling software (Hydrologic Engineering Center, 2010a). 
48 Dam-Breach Analysis and Flood-Inundation Mapping for Lakes Ellsworth and Lawtonka near Lawton, 0klahoma

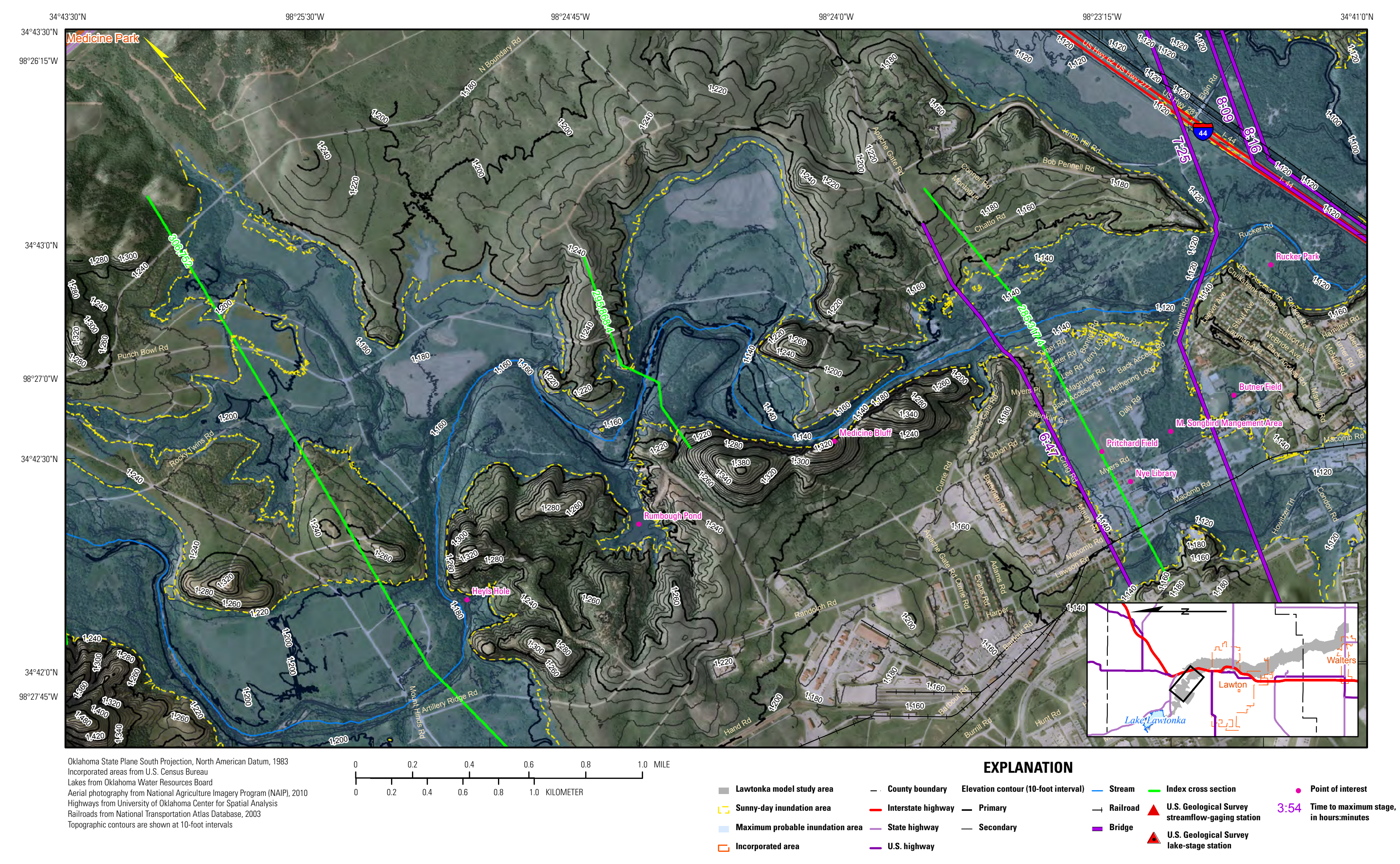

Figure 5-4. Inundated areas for dam-breach scenarios for Lake Lawtonka, near Lawton, Oklahoma, modeled by using the Hydrologic Engineering Center's River Analysis System (HEC-RAS) modeling software (Hydrologic Engineering Center, 2010a). 


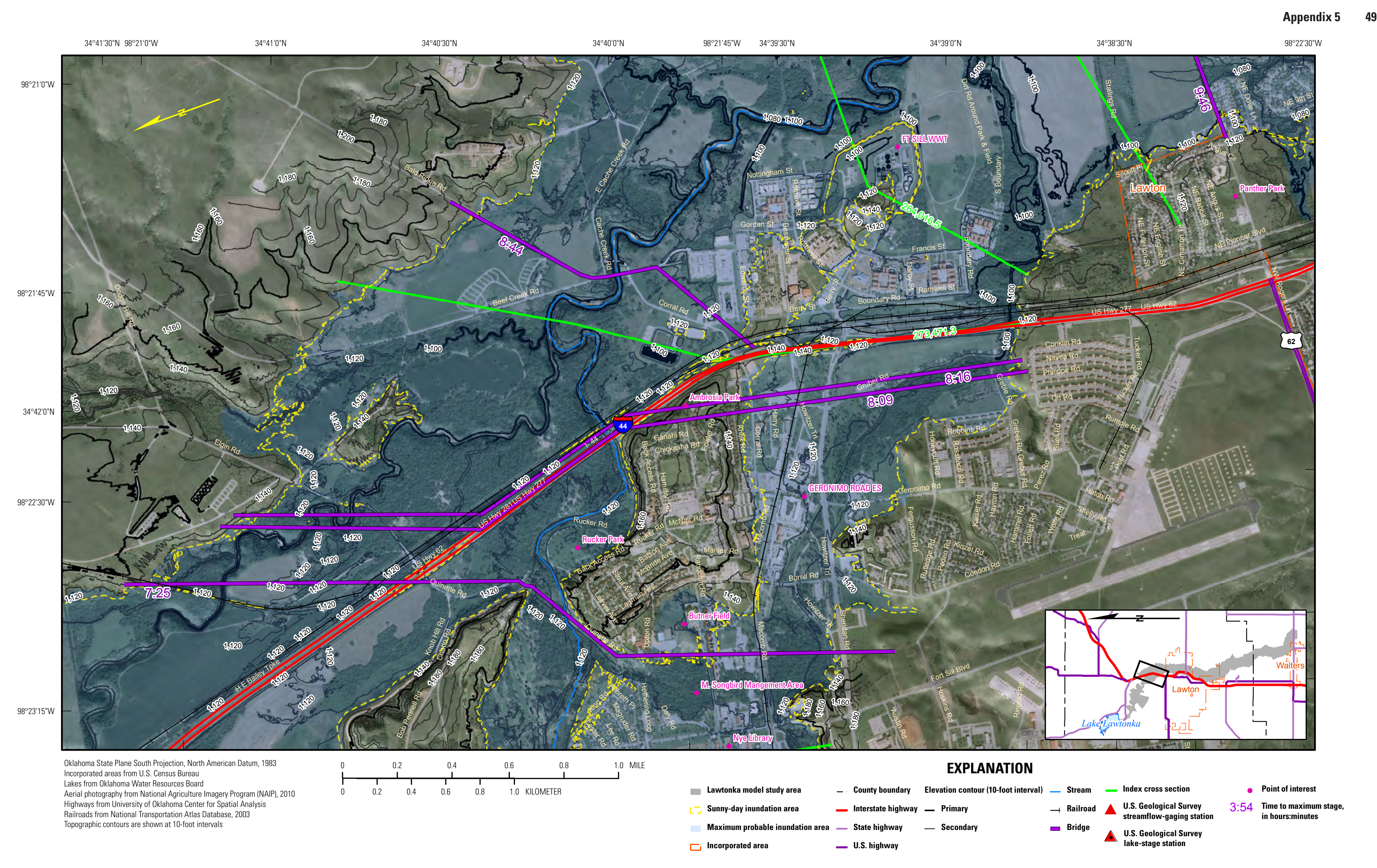

Figure 5-5. Inundated areas for dam-breach scenarios for Lake Lawtonka, near Lawton, Oklahoma, modeled by using the Hydrologic Engineering Center's River Analysis System (HEC-RAS) modeling software (Hydrologic Engineering Center, 2010a). 


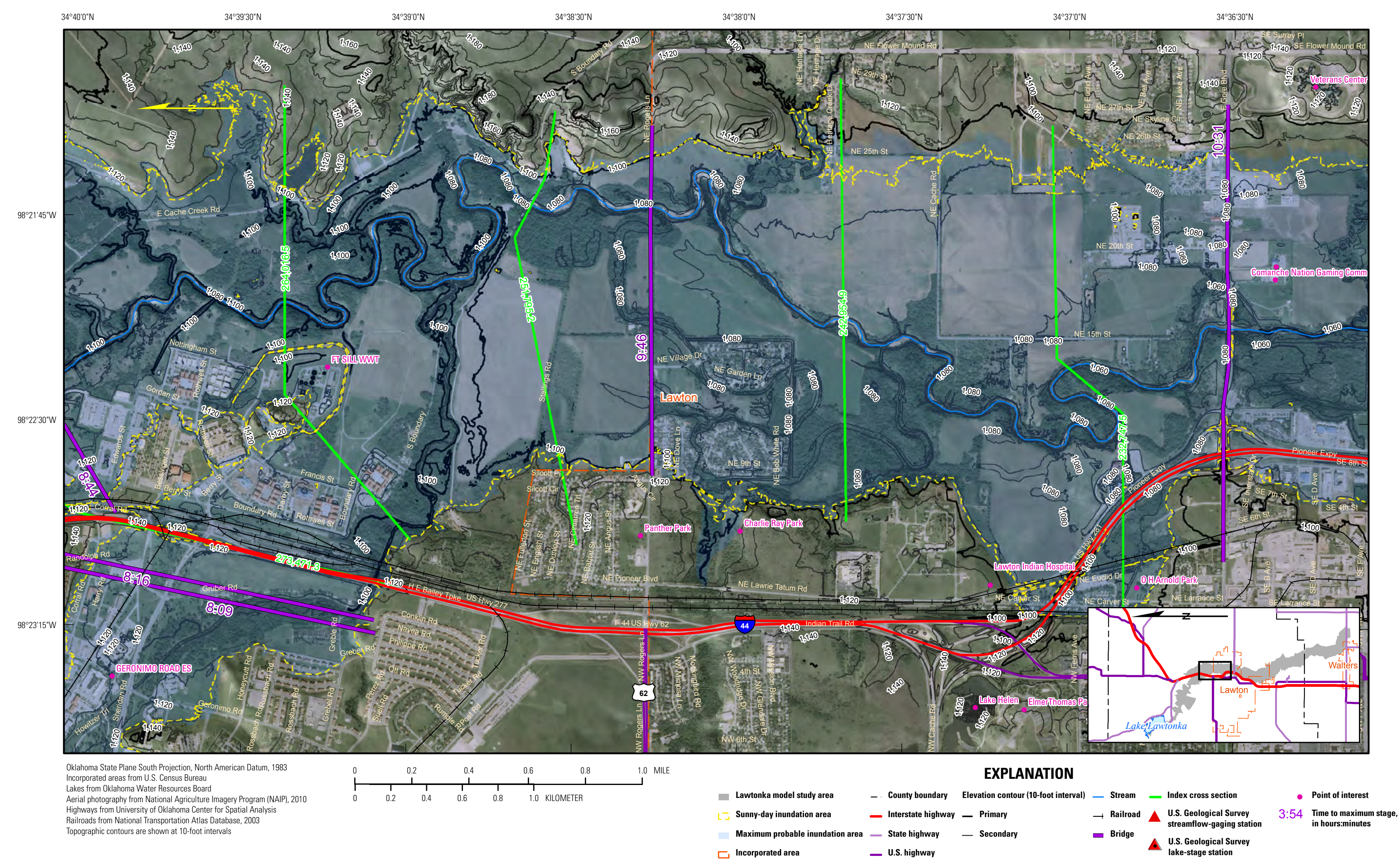

Figure 5-6. Inundated areas for dam-breach scenarios for Lake Lawtonka, near Lawton, 0klahoma, modeled by using the Hydrologic Engineering Center's River Analysis System (HEC-RAS) modeling software (Hydrologic Engineering Center, 2010a). 


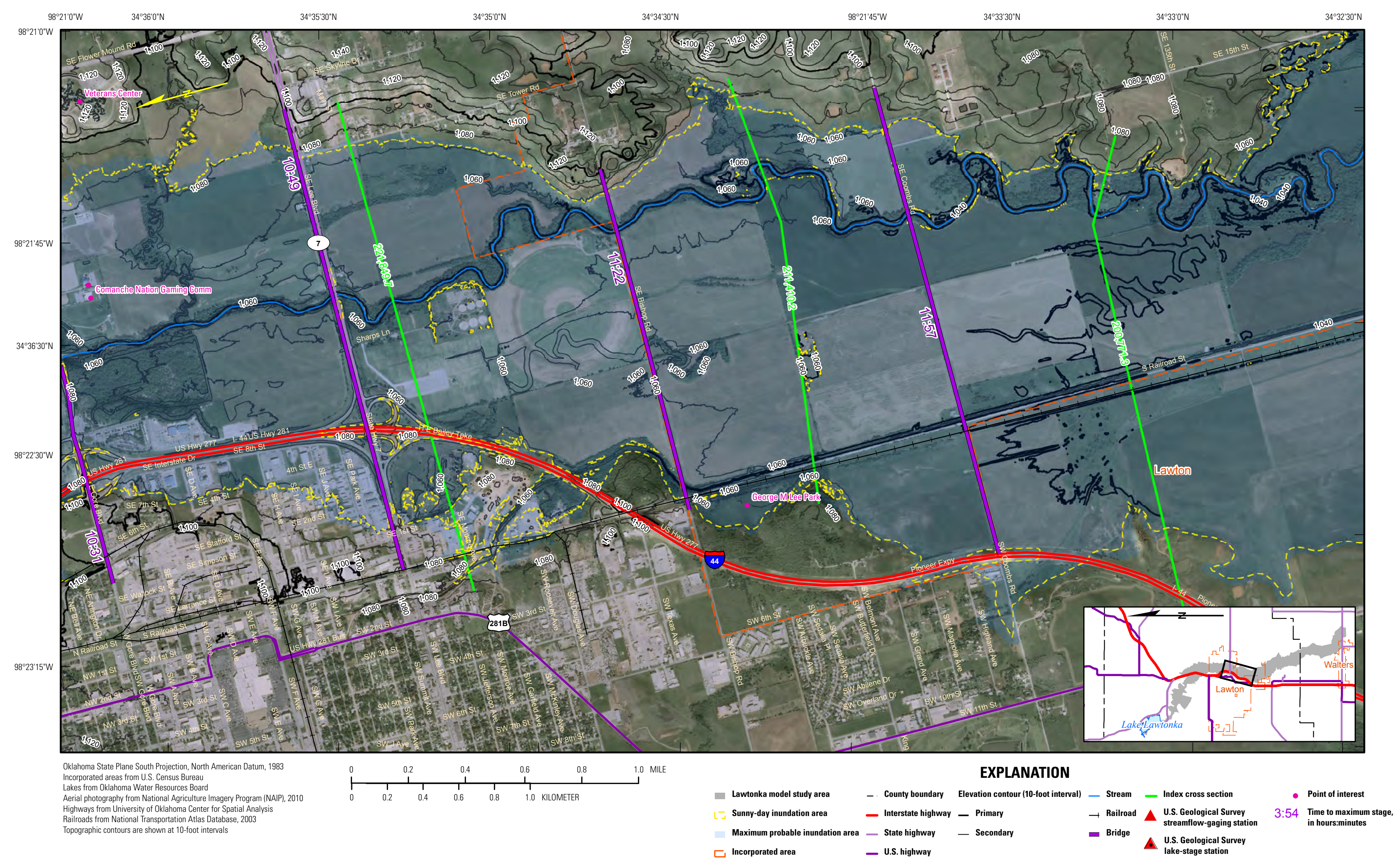

Figure 5-7. Inundated areas for dam-breach scenarios for Lake Lawtonka, near Lawton, Oklahoma, modeled by using the Hydrologic Engineering Center's River Analysis System (HEC-RAS) modeling software (Hydrologic Engineering Center, 2010a). 


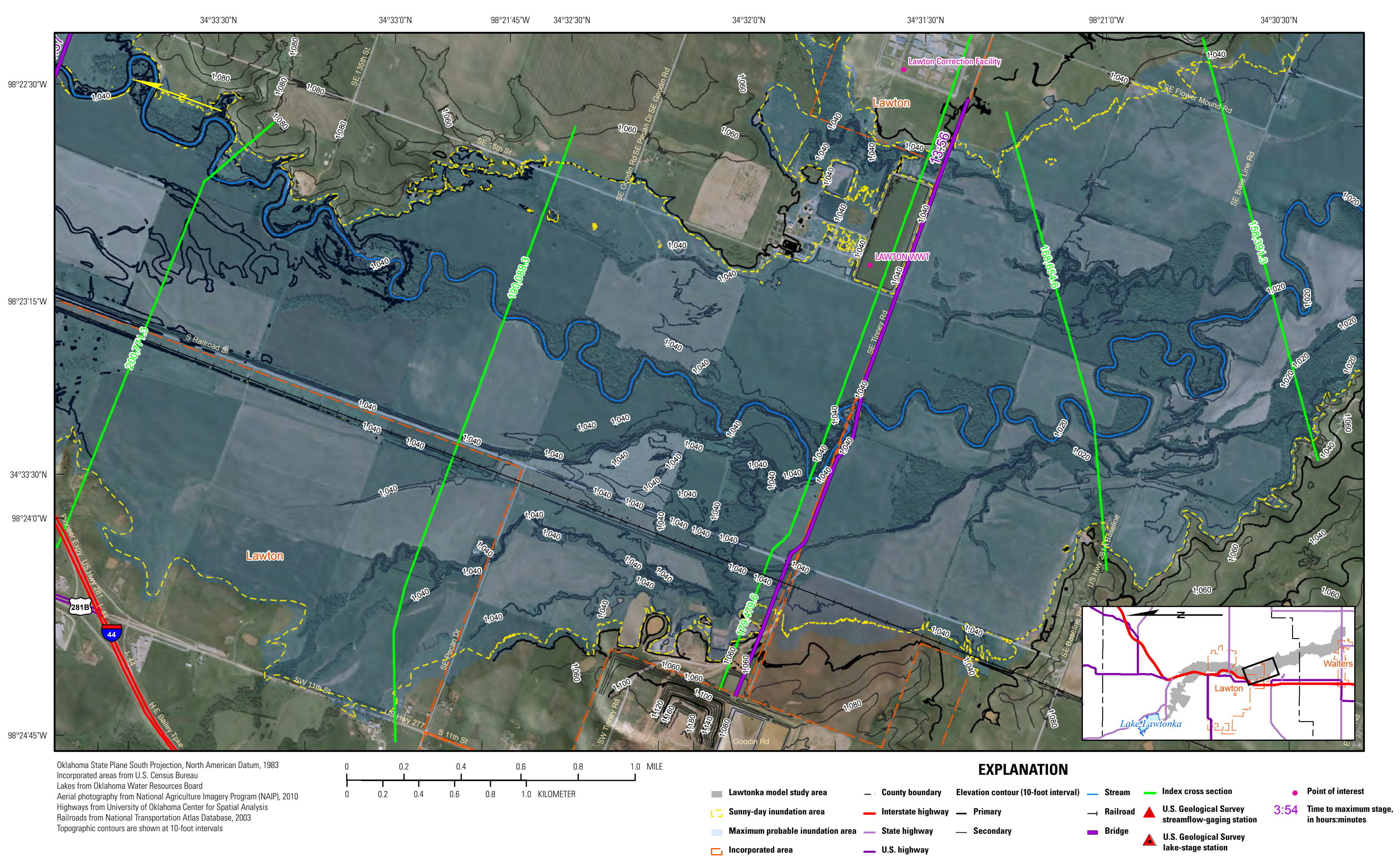

Figure 5-8. Inundated areas for dam-breach scenarios for Lake Lawtonka, near Lawton, 0klahoma, modeled by using the Hydrologic Engineering Center's River Analysis System (HEC-RAS) modeling software (Hydrologic Engineering Center, 2010a). 


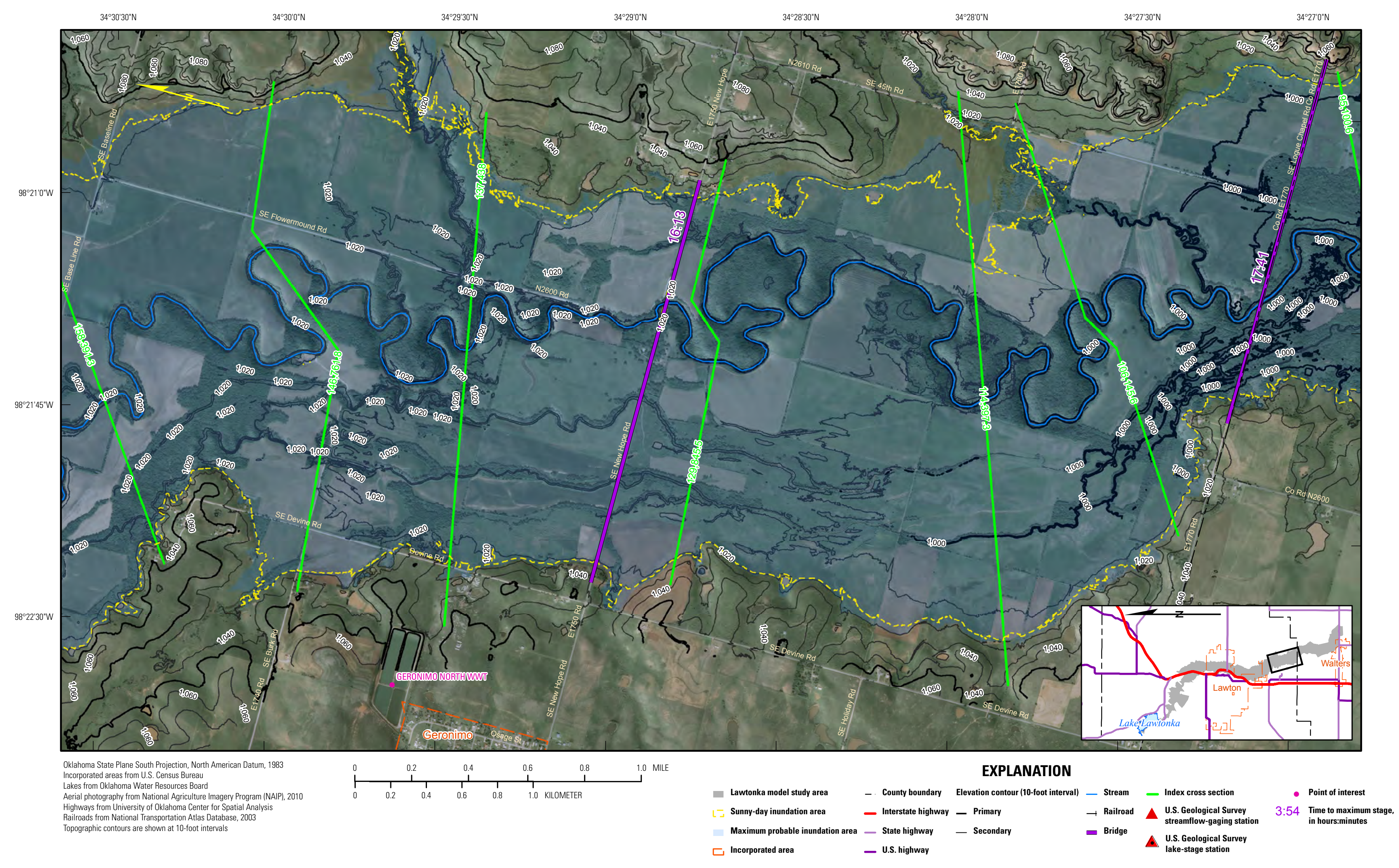

Figure 5-9. Inundated areas for dam-breach scenarios for Lake Lawtonka, near Lawton, 0klahoma, modeled by using the Hydrologic Engineering Center's River Analysis System (HEC-RAS) modeling software (Hydrologic Engineering Center, 2010a). 


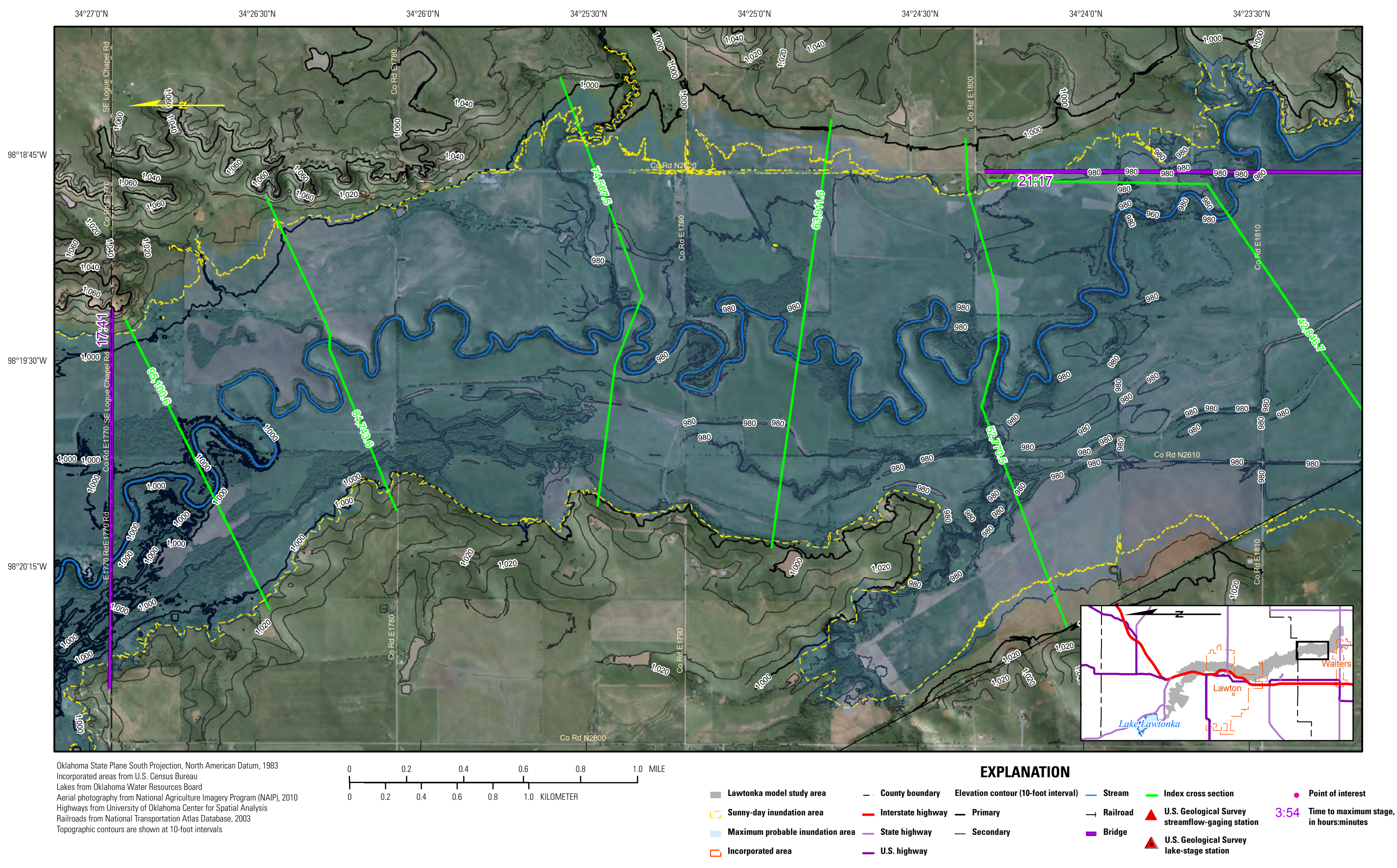

Figure 5-10. Inundated areas for dam-breach scenarios for Lake Lawtonka, near Lawton, Oklahoma, modeled by using the Hydrologic Engineering Center's River Analysis System (HEC-RAS) modeling software (Hydrologic Engineering Center, 2010a). 


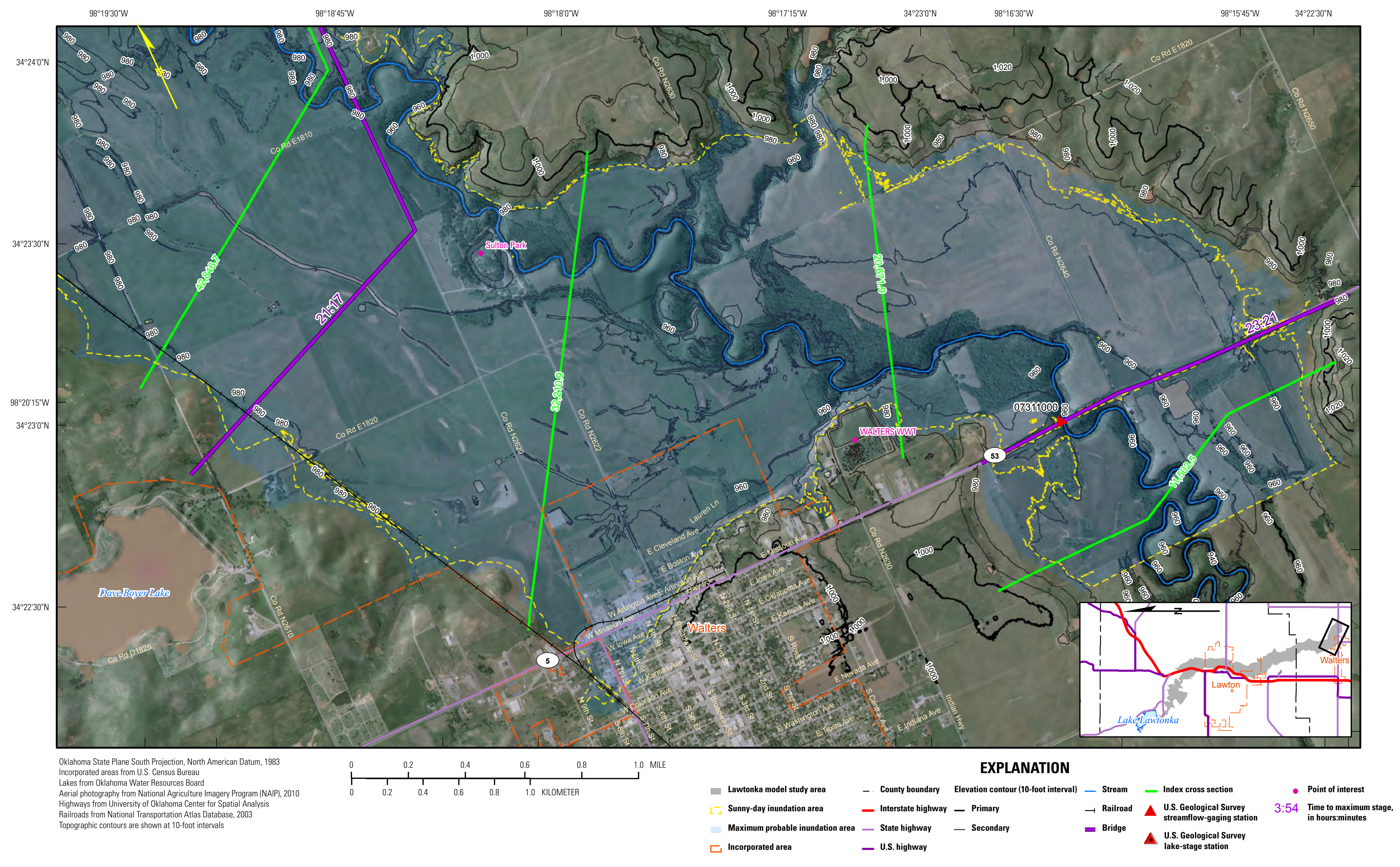

Figure 5-11. Inundated areas for dam-breach scenarios for Lake Lawtonka, near Lawton, Oklahoma, modeled by using the Hydrologic Engineering Center's River Analysis System (HEC-RAS) modeling software (Hydrologic Engineering Center, 2010a). 


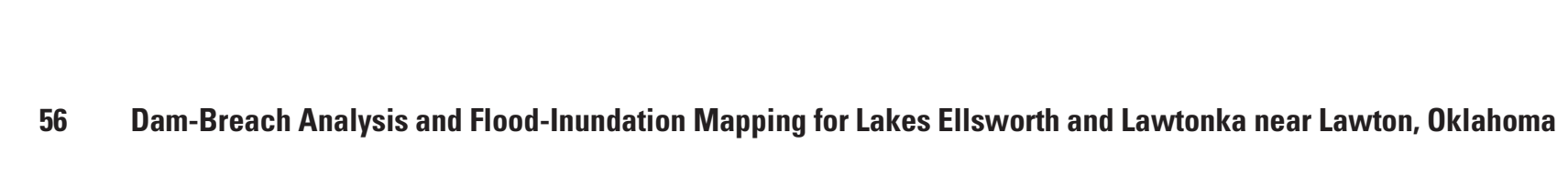




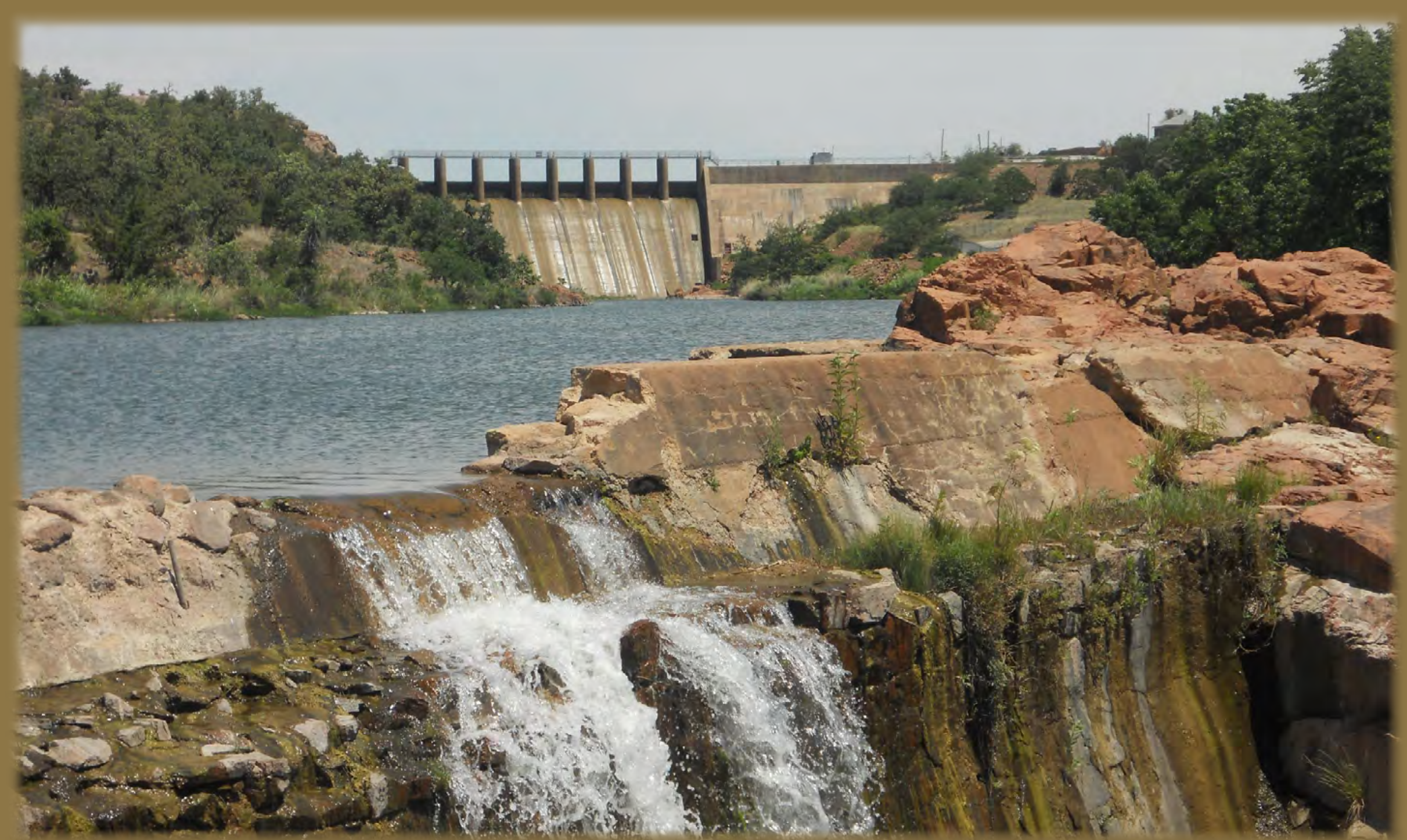

